\title{
Race, Gender, Work, and Choice: An Empirical Study of the Lack of Interest Defense in Title VII Cases Challenging Job Segregation
}

\author{
Vicki Schultz $\dagger$ and Stephen Petterson $\dagger \dagger$
}

Table of Contents

I. Major Trends in Cases Addressing the Lack of Interest Defense . . . . . . . . . . . . . . . . . . . . . . 1083

A. The Issues . . . . . . . . . . . . . . . . . . . . 1083

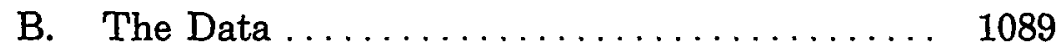

C. The Frequency and Success of the Lack of Interest Defense in Race and Sex Discrimination Cases Over Time .....................

II. The Double Standards for Interpreting Race and Sex Segregation on the Job: Judicial Responses to the Lack of Interest Defense in Race and Sex Discrimination Cases, 1967-1989 ..................

A. Alternative Theoretical Explanations for the Difference in Success Rates...............

B. A Comparison of the Content of Race and Sex Discrimination Cases................. 1113

C. A Comparison of Judicial Standards for Evaluating the Lack of Interest Defense ..........

III. The Change in Perceptions of Racial Segregation on the Job: Judicial Responses to the Lack of Interest Defense in Race Discrimination Cases in the Early

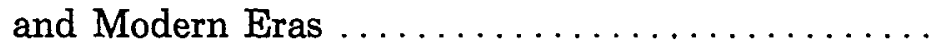

A. Alternative Theoretical Explanations for the Decline in Success Rates ................

$\dagger$ Associate Professor, University of Wisconsin Law School. The authors wish to express their appreciation to Dirk Hartog, David Trubek, Neil Komesar, Peter Carstensen, Bill Whitford, Peter Siegelman, Howard Erlanger, Gary Sandefur, and Bill Clune for their comments and encouragement. In addition, they would like to thank Kate Kruse Livermore, Alex Klass, Beth Kransberger, Sue Bonitz, Lisa Serabin, and Cate Snow for providing able research assistance. Financial support for this project was provided by the Fund for Labor Relations Studies and the University of Wisconsin Law School and Graduate School.

t† Doctoral Candidate, Department of Sociology, University of Wisconsin-Madison. 
B. A Comparison of the Content of Early and

C. A Comparison of Judicial Approaches to the

IV. The Politics of the Lack of Interest Defense: The Relationship Between Judges' Decisions and Their Political Affiliations.......................

More than twenty-five years after the enactment of Title VII of the Civil Rights Act of $1964,{ }^{1}$ the American workforce remains remarkably segregated by race and sex. ${ }^{2}$ Job segregation is not a

1 Title VII of the Civil Rights Act of 1964, 42 USC $\S \S 2000$ et seq (1988), is the major federal statute prohibiting discrimination in employment. It prohibits employers with fifteen or more employees from discriminating on the basis of race, color, religion, sex or national origin.

2 Throughout the 1980 s, approximately $60 \%$ of all male and female workers would have been required to switch to occupations atypical for their sex in order to achieve integration. See, for example, Jerry A. Jacobs, Revolving Doors: Sex Segregation and Women's Careers 20, 28-29 (Stanford, 1989); Andrea H. Beller, Trends in Occupational Segregation by Sex and Race 1960-1981, in Barbara F. Reskin, ed, Sex Segregation in the Workplace: Trends, Explanations, Remedies 11 (National Academy Press, 1984). Such estimates of occupational segregation by sex understate the degree of segregation, because even women in apparently integrated occupations tend to be employed in industries, firms, departments, and jobs that are highly segregated by sex. See, for example, William T. Bielby and James N. Baron, $A$ Woman's Place is With Other Women: Sex Segregation Within Organizations, in Reskin, ed, Sex Segregation in the Workplace at 27, 35 (finding that in a random sample of 393 California firms, $90 \%$ of the workers were employed in job titles to which only men or women were assigned); Barbara A. Gutek and Bruce Morasch, Sex-Ratios, Sex-Role Spillover, and Sexual Harassment of Women at Work, $38 \mathrm{~J}$ Soc Issues 55, $61-62$ (Winter 1983) (finding that in a representative sample of 1,232 Los Angeles workers, $42 \%$ of the women employed in male-dominated occupations reported that the other people in their jobs were mostly female).

Although occupational segregation by race has declined more rapidly than occupational segregation by sex, see Randy P. Albelda, Occupational Segregation by Race and Gender, 1958-1981, 39 Indus \& Lab Rel Rev 404, 405-06 (1986), the degree of occupational segregation by race remains substantial. See Reynolds Farley and Walter $R$. Allen, The Color Line and the Quality of Life in America 271-73 (Russell Sage Foundation, 1989) (documenting occupational segregation by race among male workers); Julianne Malveaux and Phyllis Wallace, Minority Women in the Workplace, in Karen Shallcross Koziara, Michael H. Moskow, and Lucretia Dewey Tanner, eds, Working Women: Past, Present, Future 265, 282-85 (Ind Rel Res Ass'n, 1987) (documenting occupational segregation by race among female workers). In addition, recent-research suggests that the post-1965 trend toward racial integration of occupations slowed to a halt in the late 1970s or early 1980s. See, for example, John Bound and Richard B. Freeman, Black Economic Progress: Erosion of the Post-1965 Gains in the 1980s?, in Steven Shulman and William Darity, Jr., eds, The Question of Discrimination 32, 40-41 (Weslyan, 1989). Estimates of occupational segregation by race understate the degree of segregation, because even minority workers in apparently integrated occupations tend to be concentrated disproportionately in certain industries, sectors, firms, and jobs. See, for 
separate-but-equal arrangement; minorities and women are concentrated in work offering lower wages, less status, and fewer opportunities for advancement. ${ }^{3}$ In fact, job segregation is the primary evil the statute was meant to address." Title VII promised to "break down old patterns of segregation and hierarchy,"s and to integrate minorities and women into more highly-rewarded employment.

To fulfill this statutory promise, and to reveal and root out the discriminatory employment practices that lead to job segregation, the courts have looked to statistics for evidence. From the beginning of Title VII enforcement, judges have recognized that statistical evidence plays a critical role in "uncover[ing] clandestine and covert discrimination." "Thus, in cases alleging classwide discrimi-

example, Henry Jay Becker, Racial Segregation Among Places of Employment, 58 Soc Forces 761, 765-67 (1980); Sharon M. Collins, The Making of the Black Middle Class, 30 Soc Probs 369, $377-79$ (1983); Robert L. Kaufman and Thomas N. Daymont, Racial Discrimination and the Social Organization of Industries, 10 Soc Sci Res 225 (1981); Marshall I. Pomer, Labor Market Structure, Intragenerational Mobility, and Discrimination: Black Male Advancement Out of Low-Paying Occupations, 1962-1973, 51 Am Soc Rev 650, 653-56 (1986). In particular, African American workers are heavily concentrated in public sector employment. See, for example, Michael K. Brown and Steven P. Erie, Blacks and the Legacy of the Great Society: The Economic and Social Impact of Federal Social Palicy, 29 Pub Pol 299, 306-09 (1981); Phillip I. Moss, Employment Gains By Minorities, Women in Large City Government, 111 Monthly Lab Rev 18, 18-19 (Nov 1988).

2 The most severe problem associated with job segregation is its effect on women's and minorities' earning power. A substantial portion of the male-female wage gap is attributable to women's concentration in lower-paying occupations and jobs. See, for example, Elaine Sorenson, The Wage Effects of Occupational Sex Composition: A Review and New Findings, in M. Anne Hill and Mark R. Killingsworth, eds, Comparable Worth: Analyses and Evidence 78-79 (ILR Press, 1989); US Bureau of the Census, Current Population Reports, Series P-70, No 10, Male-Female Differences in Work Experience, Occupation, and Earnings: 19844 (1987); Donald J. Treiman and Heidi I. Hartmann, eds, Women, Work, and Wages: Equal Pay for Jobs of Equal Value 33-38 (National Academy Press, 1981). Similarly, a substantial portion of the racial wage gap is associated with minorities' concentration in lower-paying occupations, jobs and sectors. See, for example, William T. Dickens and Kevin Lang, A Test of Dual Labor Market Theory, 75 Am Econ Rev 792, 802 (1985); Robert L. Kaufman, A Structural Decomposition of Black-White Earnings Differentials, 89 Am J Soc 585, 601-03 (1983).

4 See Alfred W. Blumrosen, The Duty of Fair Recruitment Under the Civil Rights Act of 1964, 22 Rutgers L Rev 465, 465 (1968); United Steelworkers of America $v$ Weber, 443 US 193, 202-03 (1979) (concluding from a review of the legislative history of Title VII that "it was clear to Congress that "the crux of the problem was to open employment opportunities for Negroes in occupations which have been traditionally closed to them' "); Johnson $v$ Transportation Agency, 480 US 616, 628 (1987) (recognizing that Title VII was intended to dismantle similar patterns of sex segregation in employment).

- Johnson, 480 US at 628, citing Weber, 443 US at 204.

- Int'l Brotherhood of Teamsters v United States, 431 US 324, 340 n 20 (1977), quoting United States $v$ Ironworkers Local 86, 443 F2d 544, 551 (9th Cir 1971), and citing other appellate decisions. 
nation, ${ }^{7}$ plaintiffs make a prima facie case of discrimination by showing that the employer has significantly underhired women or minorities relative to their representation in some larger pool of eligible workers. ${ }^{8}$ Statistical evidence enables plaintiffs to prove the existence of the patterns of segregation they seek to dismantle.

If statistical evidence is critical to realizing Title VII's purpose of eliminating job segregation, there is one defense that runs directly counter to this purpose: the "lack of interest" defense. Through this defense, employers seek to rationalize the patterns of segregation revealed by statistical evidence by arguing that such patterns resulted not from discrimination, but from protected class members' own lack of interest in the higher-paying jobs in which they are underrepresented. If credited, this argument provides a complete defense to liability. ${ }^{\theta}$ For if traditional patterns of segregation and hierarchy reflect only minorities' and women's preexisting job preferences and not employer discrimination, there is no need for judicial intervention. Thus, if widely accepted, the lack of interest defense has the potential to eviscerate Title VII's role in dismantling job segregation.

EEOC $v$ Sears, Roebuck \& Co. illustrates the dynamics of the lack of interest defense. ${ }^{10}$ The Equal Employment Opportunity Commission (EEOC) claimed that Sears had engaged in sex discrimination in selecting workers for commission sales jobs, reserving them mostly for men while relegating women to much lower-paying, noncommission sales jobs. ${ }^{11}$ To support this claim, the EEOC presented statistical studies showing that women who had applied for sales jobs at Sears were significantly less likely than men of similar qualifications to be hired for commission

7 Classwide discrimination cases include class actions initiated by private parties under Federal Rule of Civil Procedure 23 and pattern or practice cases brought by the EEOC or the Department of Justice under $\S 707$ (a) of Title VII, 42 USC $\$ 2000 \mathrm{e}-6$ (a) (1988).

- See, for example, Teamsters, 431 US at 339 n 20; Wards Cove Packing Co. $v$ Atonio, 490 US 642, 650 (1989).

- The employer may assert the lack of interest argument in an attempt to defeat the plaintiff's prima facie case. Alternatively, if the plaintiff's proof suffices to make a prima facie case, the employer may assert this argument in an attempt to establish a legitimate nondiscriminatory reason for the proven disparity. In either case, the lack of interest argument is intended to undermine the probative value of the plaintiff's statistical proof. For this reason, we sometimes refer to the lack of interest argument as a "defense."

${ }^{10} 628$ F Supp 1264 (N D Ill 1986).

11 Between 1973 and 1980 , the median hourly wages for first-year commissioned salesworkers were approximately twice as high as the median hourly wages for all noncommissioned salesworkers. See Plaintiff's Pretrial Brief-Commission Sales Issues at 27, EEOC $v$ Sears, Roebuck \& Co., 628 F Supp 1264 (N D Ill 1986) (No. 79-C-4373). 
sales. ${ }^{12}$ The district court refused to attribute this disparity to sex discrimination, however, and concluded instead that it reflected female sales applicants' own lack of interest in commission sales positions. ${ }^{13}$ According to the judge, women "disliked the perceived 'dog-eat-dog' competition" of commission selling, and preferred the security and "more enjoyable and friendly" nature of the lower-paying, noncommission sales jobs. ${ }^{14}$ In the court's eyes, Sears had done nothing to segregate its salesforce; the company had merely honored the preexisting employment preferences of working women themselves.

Although Sears was a sex discrimination case, the lack of interest defense has also been used in race discrimination cases. In fact, the defense debuted in the race discrimination context, where as early as 1967 employers sought to explain racial segregation in their workplaces as the expression of minorities' own lack of interest in higher-paying jobs. Recent Supreme Court decisions show that this reasoning retains vitality. In Wards Cove Packing Co. $v$ Atonio, the Supreme Court rejected a challenge to a system of racial stratification at two salmon canneries which was so extreme that the dissenting Justices compared it to "a plantation economy." "Th The statistical evidence showed that although almost all of the companies' low-paid cannery workers were of Filipino, native Alaskan, Samoan, Chinese or Japanese descent, few of these minorities filled the higher-paying, unskilled noncannery positions that required similar qualifications. ${ }^{16}$ Minority witnesses testified that the canneries' employment practices-including nepotism, word-of-mouth recruiting, separate hiring channels, and segregated housing and eating facilities for cannery and noncannery workers-had convinced them that it would be futile to apply for the more desirable unskilled noncannery positions. ${ }^{17}$ The Supreme

12 Between 1973 and 1980, for example, women constituted $61 \%$ of all full-time sales applicants at Sears, but only $27 \%$ of the newly hired full-time commissioned salesworkers. In contrast, women were approximately $75 \%$ of Sears' noncommissioned salesforce. See Brief for the Equal Employment Opportunity Comm'n as Appellant at 7, EEOC v Sears, Roebuck \& Co., 839 F2d 302 (7th Cir 1988) (Nos. 86-1519 and 86-1621) ("EEOC Brief"). Additional studies that controlled for any differences between male and female sales applicants on a number of different qualifications revealed similarly significant disparities. See Sears, 628 F Supp at 1296-98; EEOC Brief at 20-26.

13 Sears, 628 F Supp at 1324-25.

14 Id at 1307.

15490 US at 663 n 4 (Stevens dissenting); id at 662 (Blackmun dissenting).

16 Id at $650 \& \mathrm{n} 5$.

17 Atonio v Wards Cove Packing Co., 34 Empl Prac Dec (CCH) 33,821, 33,837-38 (W D Wash 1983). 
Court held, however, that plaintiffs had failed even to establish a prima facie case of discrimination, because "the vast majority of cannery workers did not seek jobs in unskilled noncannery positions" and "there [was] no showing that many of them would have done so even if none of the arguably 'deterring' practices existed."18 Apparently, the Court agreed with the trial judge's finding that " $[t]$ here has been a general lack of interest by cannery workers in applying for [the more lucrative] noncannery workers' jobs."19

As Sears and Wards Cove illustrate, the lack of interest defense rests on two sets of sweeping assertions about minorities' or women's work aspirations. First, the employer asserts that among the pool of eligible workers, the minorities or women are systematically less interested in higher-paying jobs than their white male counterparts. In fact, minorities and women must lack interest to a degree sufficient to explain their degree of underrepresentation in those jobs. ${ }^{20}$ In addition, the employer asserts that minorities' or women's purported lack of interest arose independently of the employer's influence. For if the employer's actions discouraged these groups from expressing an interest in the work, the employer is responsible for the resulting segregation. Thus, the validity of the defense depends also on the claim that women's or minorities' alleged aversion to higher-paying jobs arose from social and cultural forces beyond the employer's control. ${ }^{21}$ As an evidentiary matter, these assertions are difficult, if not impossible, to verify. Because

18490 US at $653-54$

19 Atonio, 34 Empl Prac Dec (CCH) at 33,829. This aspect of the Supreme Court's holding in Wards Cove has been overlooked. Even the 1991 Civil Rights Act, which overturns other parts of the Court's decision, apparently fails to address this important aspect of the holding. See Pub L No 102-166, 105 Stat 1071 (1991).

${ }^{20}$ The purpose of the lack of interest defense is to refute statistical evidence showing that the employer has underhired minorities or women relative to their representation among the larger pool of eligible workers. The lack of interest defense does not undermine the statistical evidence simply because some minorities or women lack interest in the work at issue; some whites or males undoubtedly lack interest as well. Instead, the defense succeeds if, and only if, the minorities or women in the proposed pool are sufficiently less interested in the work than their white or male counterparts to account for the degree of their underrepresentation. For a mathematical illustration of this point, see Vicki Schultz, Telling Stories About Women and Work: Judicial Interpretations of Sex Segregation in the Workplace in Title VII Cases Raising the Lack of Interest Argument, 103 Harv L Rev 1749, 1797 n 182 (1990).

${ }^{21}$ For a detailed examination and criticism of the assumption that women's job aspirations are shaped prior to and independently of their experiences in the work world, see Schultz, 103 Harv L Rev at 1815-39 (cited in note 20) (arguing that women's work aspirations are formed primarily by the structure of opportunities and social relations within labor markets and workplaces). 
people's "interest" in particular jobs and the sources of that interest are intangible factors that elude direct measurement and proof, the lack of interest defense invites courts to adopt the same sort of overbroad generalizations about women and minorities that Title VII has been construed to prohibit in other contexts. ${ }^{22}$

Indeed, on a more substantive level, the lack of interest defense appeals to some of the same images that have traditionally been used to justify women's and minorities' economic disadvantage. Women have commonly been portrayed as marginal workers, whose early socialization (or even biological predisposition) to stereotypically "feminine" roles precludes a commitment to nontraditional work. ${ }^{23}$ Implicit in such accounts is the notion, made explicit in Sears, that women workers "choose" lower-paying, female-dominated jobs to preserve their feminine identities and their familial roles. Similarly, African Americans and other minorities have frequently been depicted as undedicated workers, whose distinctive upbringing or culture fails to instill the motivation and discipline

${ }^{22}$ The only other defense that invokes such broad generalizations about protected class members as a group is the bona fide occupational qualification (BFOQ) defense, which is not available to employers in race discrimination cases. See 42 USC $\$ 2000-2(3)$ (1982). The courts have construed the $\mathrm{BFOQ}$ defense narrowly, holding that the employer must prove that "the essence of the business operation would be undermined by not hiring members of one sex exclusively," Diaz v Pan Am World Airways, 442 F2d 385, 388 (5th Cir 1971) (emphasis in original), or that "all or substantially all women would be unable to perform safely and efficiently the duties of the job involved." Weeks v Southwestern Bell Tel. \& Tel. Co., 408 F2d 228, 235 (5th Cir 1969). See also United Auto Workers $v$ Johnson Controls, 111 S Ct 1196, 1205-06 (1991). The courts have reasoned that the BFOQ defense is to be interpreted narrowly, because it draws upon precisely the sort of broad generalizations about women that Title VII was intended to prohibit. See, for example, Dothard v Rawlinson, 433 US 321, 333-34 (1977); Diaz, 442 F2d at 387; Weeks, 408 F2d at 235.

${ }^{23}$ For evidence of such views among employers, see Veronica Beechey and Tessa Perkins, A Matter of Hours: Women, Part-Time Work and the Labour Market 103-09 (Minnesota, 1987) and Cynthia Cockburn, Machinery of Dominance: Women, Men and Technical Know-How 165 (Pluto, 1985). For examples of academic research that attributes job segregation to women's preexisting preferences rather than to labor market discrimination, see Gary S. Becker, Human Capital, Effort, and the Sexual Division of Labor, $3 \mathrm{~J}$ Lab Econ S33 (1985) (arguing that women choose lower-paying, female-dominated jobs to conserve energy for their domestic obligations); Richard B. Freeman, Availability, Goals and Achievements in Affirmative Action; Economic Perspective, in Equal Employment Advisory Council, Perspectives on Availability: A Symposium on Determining Protected Group Representation in Internal and External Labor Markets 93, 97 (EEAC, 1978) ("'W]omen may have, for reasons of preference, biology, or their position as a secondary earner, different job preferences than men. They may prefer working in an office or doing lighter factory work than men and thus congregate in certain occupational areas."). For summaries and criticisms of this sort of gender bias in academic research, see Mary Lindenstein Walshok, BlueCollar Women: Pioneers on the Male Frontier 270-76 (Anchor, 1981); Roslyn L. Feldberg and Evelyn Nakano Glenn, Male and Female: Job Versus Gender Models in the Sociology of Work, 26 Soc Probs 524 (1979). 
necessary for higher-level employment. ${ }^{24}$ According to such explanations, apparently adopted by the Supreme Court in Wards Cove, minority workers select and stay in lower-paying jobs because they lack the initiative to pursue better alternatives. Appeals to such accounts, which tend to romanticize women and denigrate minorities, produce similar effects in Title VII cases. By portraying segregation as the expression of women's or minorities' preexisting job preferences, and by attributing their preferences to social and cultural forces beyond employers' control, the lack of interest defense privatizes job segregation and places it beyond the responsibility of employers and courts.

Although the lack of interest defense has the potential to frustrate Title VII's purpose of eliminating job segregation, there has been little systematic study of how the courts have responded to this defense. ${ }^{25}$ This Article analyzes judicial responses to the lack of interest defense in all published Title VII race and sex discrimi-

24 For evidence of such attitudes among employers, see Joleen Kirshenman and Kathryn M. Neckerman, "We'd Love to Hire Them, But. . .": The Meaning of Race for Employers, in Christopher Jencks and Paul E. Peterson, eds, The Urban Underclass 203, 213 (Brookings Institute, 1991) (quoting Chicago area employers for the view that African American workers "have a bad work ethic, they create tension in the work place, they are lazy and unreliable, they have a bad attitude"). For evidence of such attitudes among the general public, see James R. Kluegel, "If There Isn't a Problem, You Don't Need a Solution": The Bases of Contemporary Affirmative Action Attitudes, 28 Am Behav Scientist 761, 766 (1985) (reporting that in a 1977 public opinion survey, two-thirds of all whites believed that African Americans had worse jobs and lower income "because most blacks don't have the motivation or will power to pull themselves up out of poverty"). In addition, neoconservative academics attribute racial differences in economic status not to labor market discrimination, but to minorities' independently acquired cultural characteristics, including their alleged failure to internalize the ethic of hard work and discipline. See, for example, George Gilder, Wealth and Poverty 64-74 (Basic, 1981); Thomas Sowell, Civil Rights: Rhetoric or Reality? 46-47 (William Morrow, 1984). For summaries and criticisms of the neoconservative position, see Thomas D. Boston, Race, Class and Conservatism 54-92 (Unwin Hyman, 1988); Kimberle Williams Crenshaw, Race, Reform, and Retrenchment: Transformation and Legitimation in Antidiscrimination Law, 101 Harv L Rev 1331, 1379 80 (1988).

25 Although numerous feminist scholars have discussed the Sears case-see, for example, Ruth Milkman, Women's History and the Sears Case, 12 Feminist Stud 375 (1986); Joan W. Scott, Deconstructing Equality-Versus-Difference: Or, the Uses of Poststructuralist Theory for Feminism, 14 Feminist Stud 33, 38-47 (1988); Joan C. Williams, Deconstructing Gender, 87 Mich I Rev 797, 813-21 (1989)-only Schultz's earlier study provided a systematic examination of how federal courts have responded to the lack of interest defense in sex discrimination cases. See Schultz, 103 Harv L Rev 1749 (cited in note 20). Scholars have devoted even less attention to analyzing how this defense has fared in race discrimination cases. Other than Schultz's study and a 1977 article by David Copus, The Numbers Game is the Only Game in Town, 20 Howard L J 374, 396 (1977), we are not aware of any work that has discussed the courts' treatment of the lack of interest argument in the race discrimination context. 
nation cases decided since 1965 . Our analyses of the results, evidentiary standards, and reasoning in these cases suggest that the courts have compromised both women's and minorities' protections against job segregation. We document two distinct but equally disturbing trends.

We find, first, that the courts have responded to the lack of interest defense with a gender bias. Section I shows that in the 1965-1989 period as a whole, the courts have been considerably more likely to credit the lack of interest defense in sex discrimination cases than in race discrimination cases. Although theoretically it is possible that this disparity arose because sex discrimination plaintiffs presented weaker cases for rejecting the lack of interest defense than race discrimination plaintiffs, the data do not support this explanation. Our analyses of the content of the cases in Section II show that the sex discrimination cases are not weaker than the race discrimination cases to a degree sufficient to explain the disparity in plaintiffs' success rates. Rather, we demonstrate that judges have not applied the same standards for evaluating the validity of the lack of interest defense in sex and race discrimination cases, but have treated the same types of evidence and facts differently. On the whole, judges have imposed more stringent standards of proof for refuting the lack of interest defense on sex discrimination plaintiffs than on race discrimination plaintiffs. Section IV presents evidence that judges affiliated with the Republican party are primarily responsible for the disparity in sex and race discrimination plaintiffs' success rates.

The courts' double standards for sex and race discrimination cases reflect gender bias in the way judges have understood the dynamics of job segregation. Like the dominant culture, the courts have assumed that women's work aspirations and identities are shaped exclusively through early socialization or even innate predispositions, rather than in response to labor market conditions. As a result, judges have imposed heavy burdens on sex discrimination plaintiffs to overcome the presumption that sex segregation is the expression of women's own culturally (or even biologically) inspired "differences" in job preferences. In the race discrimination context, by contrast, the courts acknowledged early on that minorities' work aspirations had been formed and artificially limited in response to a discriminatory labor market. Historically, because judges presumed that any racial differences in job preferences had been forged in the context of employment discrimination, they were less inclined to rationalize racial segregation as the reflection of minorities' own cultural "differences." 
Since the late 1970s, however, the courts have retreated from their traditional approach to the lack of interest defense in race discrimination cases. Section I demonstrates that race discrimination plaintiffs' success against the lack of interest defense plummeted after 1977. Section III shows that changes in the strength and evidentiary composition of the race discrimination cases cannot fully account for the dramatic degree of plaintiffs' losses. Since 1978 , the courts have been more likely to accept the lack of interest defense even in strong cases in which they previously would have rejected it. In addition, judges have responded to the key types of evidence in a manner that is far less favorable to plaintiffs. These findings suggest that in the more recent period, the courts have simply become more predisposed to attribute racial segregation to minorities' preexisting job preferences. Remarkably, Section IV suggests that this shift affected judges across the entire political spectrum. Judges affiliated with the Democratic and Republican parties, and judges appointed by presidents from Eisenhower to Carter, all became more likely to accept the lack of interest defense in race discrimination cases after 1977.

Taken together, our findings suggest that the courts have moved toward a more conservative understanding of racial segregation that converges with the way they have traditionally understood sex segregation. Just as the courts have always tended to excuse sexual inequality in employment as the expression of culturally (or biologically) created gender differences in work aspirations, judges have also begun to rationalize racial inequality in employment as the reflection of racial differences in work preferences that are not rooted in larger labor market conditions. As a consequence of these views, there is little role for the law in constituting-or changing - the dynamics that lead to race and sex segregation on the job.

After explaining the context and data for our study, Section I documents the two trends in success rates described above. Section II examines the difference in plaintiffs' success rates in race and sex discrimination cases, and analyzes the content of the cases to evaluate alternative explanations for this disparity. Section III employs similar methods to investigate the reasons for the decline in plaintiffs' success in race discrimination cases since the late 1970s. Section IV examines the relationship between judges' decisions on the lack of interest defense and their political affiliations. 
I. Major Trends in Cases Addressing the

LACK OF INTEREST DefENSE

A. The Issues

This Article is part of a larger project to analyze all published federal court decisions that have addressed the lack of interest defense since Title VII's enactment. Our objective here is to address two major questions: (1) Have the courts responded to the lack of interest defense similarly in race and sex discrimination cases over the past twenty-five years? and (2) Have the courts altered their approach to this defense in race discrimination cases over time?

Our focus on these issues is framed, in part, by the results of earlier work by the senior author. In Telling Stories About Women and Work: Judicial Interpretations of Sex Segregation in the Workplace in Title VII Cases Raising the Lack of Interest Argument, ${ }^{28}$ Schultz analyzed all published sex discrimination cases that have addressed the lack of interest defense since 1965. Her analysis showed that from the beginning, the courts have assumed that women's work interests and identities are shaped in private realms of life that are independent of and prior to the work world. In this view, early socialization (or even biological factors) influences women to develop stable aspirations for "feminine" jobs before they ever begin working or searching for work; their preferences constitute predetermined inputs into the labor market. Because this view attributes little or no role to employers in creating sex segregation, the courts required plaintiffs to meet difficult burdens to prove that sex segregation had not resulted from women's own preexisting job preferences. As part of the earlier study, Schultz showed that the courts' approach in sex discrimination cases was not inevitable. The courts had taken a far more progressive, pro-plaintiff approach in an early body of race discrimination cases. In the early race discrimination cases, the courts assumed that minorities' work aspirations had been formed and artificially limited in response to discriminatory labor market conditions. An insistence that employers change those conditions led judges to evaluate the evidence in a manner more favorable to plaintiffs. ${ }^{27}$

This Article examines two important issues that were raised by Schultz's earlier work. First, we undertake a more comprehensive comparison of the courts' responses to the lack of interest defense in race and sex discrimination cases decided since the enact-

\footnotetext{
28 Schultz, 103 Harv L Rev at 1749 (cited in note 20).

27 Id at 1771-75.
} 
ment of Title VII. Although the analysis of race discrimination cases in Telling Stories was limited to cases decided between 1965 and 1971, the difference in the courts' treatment of the lack of interest defense in race and sex discrimination cases suggested by that limited comparison was striking. Numerous commentators have pointed to the courts' failure to accord sex discrimination the same serious scrutiny as race discrimination in other areas of law. ${ }^{28}$ Because our society's conceptions of gender are deeply rooted in the sexual division of labor, ${ }^{29}$ dominant cultural images of women as uncommitted workers who prefer less challenging, "feminine" jobs may have been more deeply ingrained in the national and judicial consciousness than images of racial minorities as undedicated workers who desire less rewarding, racially-stereotyped jobs. The EEOC's early failure to treat sex segregation in employment as seriously as racial segregation provides an example of such biased attitudes. ${ }^{30}$ Indeed, the standard interpretation of the original

${ }^{28}$ See, for example, Ann E. Freedman, Sex Equality, Sex Differences, and the Supreme Court, 92 Yale L J 913, 925-26 (1985); Ruth Bader Ginsburg, Sexual Equality Under the Fourteenth Amendment and Equal Rights Amendments, 1979 Wash U L Q 161, 164-72; Sylvia A. Law, Rethinking Sex and the Constitution, 132 U Pa L Rev 955, 979-98 (1984); Catharine A. MacKinnon, Sexual Harassment of Working Women 14, 97-99, 127-41 (Yale, 1979); Wendy W. Williams, The Equality Crisis: Some Reflections on Culture, Courts, and Feminism, 7 Women's Rts L Rep 175, 178 (1982).

29 The dominant culture defines "masculinity" and "femininity" largely in terms of economic "breadwinner" versus "dependent" status, respectively. Susan Faludi's recent review of two decades of public attitude surveys powerfully confirms this theme. Faludi states:

For twenty years, ... pollsters have asked [their] subjects to define masculinity. And for twenty years, the leading definition, ahead by a huge margin, has never changed. It isn't being a leader, athlete, lothario, decision maker, or even just being "born male." It is simply this: being a "good provider for his family." If establishing masculinity depends most of all on succeeding as the prime breadwinner, then it is hard to imagine a force more directly threatening to [] American manhood than ... [women's] drive for economic equality.

Susan Faludi, Backlash: The Undeclared War Against American Women 65 (Crown, 1991).

so The EEOC's early failure to treat Title VII's prohibition against sex discrimination as seriously as the prohibition against race discrimination is well documented. See, for example, Jane De Hart-Mathews, The New Feminism and the Dynamics of Social Change, in Linda K. Kerber and Jane De Hart-Mathews, eds, Women's America: Refocusing the Past 437, 447-48 (Oxford, 1987) ("Despite the fact that the law proscribed discrimination on the basis of sex as well as race, the commission refused to take seriously the problem of sexual discrimination. The first executive director of the EEOC ... regarded the sex provision as a 'fluke' best ignored."). It was not until 1969, for example, that the EEOC's guidelines on sex discrimination prohibited employers from using sex-segregated advertising for jobs. Compare 29 CFR $\$ 1604.4(b)$ (1966) (permitting advertising placements under "Male" and "Female" headings to convey "that some occupations are considered more attractive to persons of one sex than the other"), with 29 CFR \& 1604.5 (1989) (prohibiting such placements unless sex is a bona fide occupational qualification for the job). Similarly, it was not until 1969 that the EEOC's guidelines prohibited employers from relying on state laws restricting women to certain employment to defend sex segregation in their workforces. See Barbara 
1964 Act's prohibition against sex discrimination as a "joke"-rather than a serious response to the injustice of women's economic plight-may also evidence such bias. ${ }^{31}$ The long history of labor market discrimination against women is welldocumented. ${ }^{32}$

Despite Title VII's inauspicious "story of origins,"3s Congress made clear when it amended Title VII in 1972 that sex segregation

Allen Babcock, et al, Sex Discrimination and the Law: Causes and Remedies 267 (Little, Brown, 1975).

${ }^{31}$ Sources interpreting the original 1964 Act's prohibition against sex discrimination as a "joke"-a last-ditch effort by opponents to defeat the more important ban on racial discrimination-are so ubiquitous that this view has become the standard interpretation of the statute's history. See, for example, Arthur B. Smith, Jr., Employment Discrimination Law: Cases and Materials 327 (Bobbs-Merrill, 1978); Note, Developments in the Law; Employment Discrimination and Title VII of the Civil Rights Act of 1964, 84 Harv L Rev 1109, 1167 (1971); Sex and Nonsense, The New Republic 10 (Sep 4, 1965); Wetzel v Liberty Mutual Ins. Co., 511 F2d 199, 204 (3d Cir 1975).

Some scholars have challenged this interpretation. For example, Michael Gold has argued that even if the members of Congress who introduced the amendment adding the prohibition against sex discrimination did so for the purpose of attempting to defeat the bill, the majority of Congress did not share that motivation when they approved the amendment. See Michael Evan Gold, A Tale of Two Amendments: The Reasons Congress Added Sex to Title VII and Their Implication for the Issue of Comparable Worth, 19 Duquesne L Rev 453, 457-69 (1981). As Gold points out, the House of Representatives approved the amendment adding the ban on sex discrimination on two separate occasions. On the second occasion, a majority of the House voted for the amendment, and then voted to approve the entire bill. According to Gold, "[i]t would be absurd to believe that the Representatives who approved the [ ] amendment [ ] wanted to impair the very bill which they promptly approved by an overwhelming margin." Id at 461 . Those who spoke in favor of the amendment spoke at length about the injustice of employer discrimination relegating women (or at least white women) to the least desirable jobs because of their sex. See, for example, 110 Cong Rec 2579-81 (Feb 8, 1964) (remarks of Representatives Griffiths and St. George). To conclude on the basis of this limited legislative history that Congress adopted the amendment because of a desire to defeat the legislation, rather than to respond to the inequity of women's economic plight, may require an implicit assumption that sex discrimination in employment was less deserving of congressional attention than racial discrimination.

32 For examples of historical work documenting labor market discrimination that relegated women to less desirable, female-dominated jobs, see Philip Sheldon Foner, Women and the American Labor Movement: From the First Trade Unions to the Present 497 (Free Press, 1980); Maurine Weiner Greenwald, Women, War and Work: The Impact of World War I on Women Workers in the United States 9-10, 22-23, 94-99 (Cornell, 1980); Jacqueline Jones, Labor of Love, Labor of Sorrow: Black Women, Work, and the Family from Slavery to the Present 179-80, 104-05 (Basic, 1985); Susan Estabrook Kennedy, If All We Did Was To Weep at Home: A History of White Working-Class Women in America (Indiana, 1979); Alice Kessler-Harris, Out to Work: A History of Wage-Earning Women in the United States (Oxford, 1982); and Ruth Milkman, Gender at Work: The Dynamics of Job Segregation By Sex During World War II (lllinois, 1987).

${ }^{33}$ In this context, the "story of origins" refers to the constitutive myths and ideals we ascribe both to Title VII's ban on sex discrimination, and to ourselves as a nation and as a people in having enacted the legislation. See Richard Delgado, On Taking Back Our Civil Rights Promises: When Equality Doesn't Compute, 1989 Wis L Rev 579, 580 n 6, adopting 
is a serious form of employment discrimination that courts must treat with the same degree of concern as they treat race discrimination and all other forms of discrimination. ${ }^{34}$ Furthermore, the Supreme Court has used the same approaches to analyze Title VII race and sex discrimination cases, ${ }^{35}$ and has suggested that the same standards apply for evaluating the lack of interest argument in both contexts. ${ }^{36}$ We examine whether the lower courts have followed the congressional mandate and the Supreme Court's lead, or whether cultural bias has instead led the courts to impose more difficult standards on sex discrimination plaintiffs.

the term from Milner S. Ball, Stories of Origins and Constitutional Possibilities, 87 Mich L Rev 2280 (1989).

34 When Congress amended Title VII in 1972, both the House and the Senate made clear that they viewed sex segregation as a primary evil that the statute was intended to address. See H R Rep No 92-238, 92 d Cong, 1st Sess 4-5, reprinted in 1972 USCCAN 2137, 2140 (" $[W]$ omen are placed in the less challenging, the less responsible and the less remunerative positions on the basis of their sex alone. Such blatantly disparate treatment is particularly objectionable in view of the fact that Title VII has specifically prohibited sex discrimination since its enactment in 1964."); S Rep No 92-415, 92d Cong, 1st Sess 7 (1971) (including similar statements). Congress emphasized that the courts were to treat sex discrimination with the same seriousness as race discrimination or any other form of prohibited discrimination. See, for example, S Rep No $92-415$ at 7 ("While some have looked at . . . women's rights as a frivolous divertissement, this Committee believes that discrimination against women is no less serious than other prohibited forms of discrimination, and that it is to be accorded the same degree of concern given to any type of similarly unlawful conduct."); and H R Rep No 92-238 at 5 ("Discrimination against women is no less serious than other forms of prohibited employment practices and is to be accorded the same degree of social concern given to any type of unlawful discrimination."). See also Barnes $v$ Costle, 561 F2d 983, 987 (DC Cir 1977).

3s See, for example, Johnson v Transportation Agency, 480 US 616, 631 (1987) (upholding the validity under Title VII of an affirmative action plan for women after applying the same analysis it had used in United Steelworkers of America $v$ Weber, 443 US 193 (1979), a case construing the validity of an affirmative action plan for Blacks); Meritor Sav. Bank $v$ Vinson, 477 US 57, 66-67 (1986) (citing decisions recognizing a cause of action for racial harassment under Title VII to support the recognition of a cause of action for sexual harassment under Title VII).

${ }^{36}$ In Dothard v Rawlinson, 433 US 321, 330 (1977), a sex discrimination case, the Court supported its analysis of the lack of interest issue with a reference to its earlier analysis of the same issue in a race discrimination case, Int'l Brotherhood of Teamsters $v$ United States, 431 US 324, 365-67 (1977). Subsequently, in Johnson, a majority of the Court upheld the validity under Title VII of an affirmative action program for women, concluding that the plan was justified by the "manifest imbalance that reflected underrepresentation of women in "traditionally segregated job categories.' " 480 US at 631, citing Weber, 443 US at 197. The Court rejected Justice Scalia's position, which sought to distinguish Weber, a race discrimination case, on the ground that the absence of women from road maintenance work was attributable to women's own lack of interest rather than to the employer's historical discrimination. See Johnson, 480 US at 668 (Scalia dissenting) ("[Road maintenance work] is a 'traditionally segregated job category' not in the Weber sense, but in the sense that, because of longstanding social attitudes, it has not been regarded by women themselves as desirable work.") (emphasis in original). 
In addition, we investigate whether the courts have retreated from their traditional approach to the lack of interest defense in race discrimination cases. Just as cultural bias may have influenced the courts to apply heightened standards for evaluating the lack of interest defense in sex discrimination cases, so too shifting attitudes toward race relations may have induced judges to back away from their early pro-plaintiff approach to this defense in race discrimination cases. The early race discrimination cases discussed in Telling Stories were decided in the immediate aftermath of the civil rights movement-a time when many federal judges understood racial discrimination to be pervasive and believed that Title VII required them to dismantle entrenched structures of racial hierarchy ${ }^{37}$ Today, by contrast, despite evidence that employers continue to practice racial discrimination, ${ }^{38}$ we inhabit a period that is widely described as the "post-Civil Rights era." Recent Supreme Court decisions have departed from established civil rights approaches so dramatically that Congress has found it necessary to restore protections the Court had dismantled..$^{39}$

This change did not occur in a vacuum. During the late 1970s, the Supreme Court had already begun to reject some of the more expansive approaches the lower courts had developed for combatting employment discrimination. ${ }^{40} \mathrm{By}$ that time, affirmative action

${ }^{37}$ See, for example, Alfred W. Blumrosen, The Law Transmission System and the Southern Jurisprudence of Employment Discrimination, 6 Indus Rel L J 313, 316, 340-44 (1984); Jack Bass, Unlikely Heroes 322-23 (Simon and Schuster, 1981).

${ }^{38}$ See, for example, Jomills Henry Braddock II and James M. McPartland, How Minorities Continue to be Excluded From Equal Employment Opportunities: Research on Labor Markets and Institutional Barriers, $43 \mathrm{~J}$ Soc Issues 5 (1987); Randall Samborn, Many Americans Find Bias At Work, Natl L J 1 (Jul 16, 1990); Marjery Austin Turner, Michael Fix, and Raymond J. Struyk, Opportunities Denied, Opportunities Diminished: Discrimination in Hiring (Urban Institute, 1991).

s9 After vetoing an earlier bill that had been passed by nearly two-thirds of the House and Senate, see the Civil Rights Act of 1990, S 2104, 101st Cong, 2d Sess, 136 Cong Rec 364 (daily ed, Feb 7, 1990), President Bush signed into law a compromise bill intended to reverse some of the Supreme Court's recent restrictive interpretations of Title VII. See the Civil Rights Act of 1991, Pub L No 102-166, 105 Stat 1071 (1991). During the signing ceremony, however, President Bush endorsed an interpretive memorandum submitted by Senator Dole, which described the bill as "an affirmation of existing law," including the Supreme Court decisions it was designed to reverse. See President Bush's Statement on Signing the Civil Rights Act of 1991, 226 Daily Labor Report (BNA) D-1 (Nov 22, 1991); Andrew Rosenthal, Reaffirming Commitment, Bush Signs Rights Bill, NY Times A1 (Nov 21, 1991).

10 See, for example, Int'l Brotherhood of Teamsters $v$ United States, 431 US 324, 35354 (1977) (invalidating the use of the disparate impact model to challenge seniority systems that perpetuate the effects of pre-Title VII discrimination); East Texas Motor Freight Sys., Inc. v Rodriguez, 431 US 395, 405-06 (1977) (restricting the use of "across-the-board" class actions in Title VII litigation); Regents of the Univ. of California $v$ Bakke, 438 US 265, 305 (1978) (Powell) (invalidating a race-conscious program intended to achieve greater racial 
had come under serious attack, ${ }^{41}$ and neo-conservative accounts that attribute racial differences in occupational attainment to minorities' own attitudes or culture rather than to labor market discrimination were beginning to gain prominence. ${ }^{42}$ These same currents appeared in the attitudes of white Americans generally. By 1976, almost three-quarters of all whites believed that African Americans and other minorities "no longer face[d] unfair employment conditions." 43 They also believed that minorities' economic disadvantage was the result of their own lack of initiative and effort. In 1977, almost two-thirds of white Americans attributed African Americans' economic deprivation to the fact that "most blacks don't have the motivation or will power to pull themselves up out of poverty." ${ }^{44}$ In such a political climate, the lack of interest

diversity in medical school admissions); Washington v Davis, 426 US 229, 239 (1976) (requiring proof of discriminatory intent to establish that racial disparities in employment violate the Fourteenth Amendment); Personnel Admin. of Massachusetts v Feeney, 442 US 256,274 (1979) (adopting a narrow definition of the intent required to establish sex discrimination under the Fourteenth Amendment).

For scholarship documenting the courts' retreat in the late 1970s, see Blumrosen, 6 Indus Rel L J at 340-46 (cited in note 37); Jerome M. Culp, A New Employment Policy for the 1980's: Learning From the Victories and Defeats of Twenty Years of Title VII, 37 Rutgers L Rev 895 (1985); Alan David Freeman, Legitimizing Racial Discrimination Through Antidiscrimination Law: A Critical Review of Supreme Court Doctrine, 62 Minn L Rev 1049, 1079-1118 (1978). Derrick A. Bell, Jr., Race, Racism and American Law 619, 622-23 (Little, Brown, 2d ed 1980).

"See, for example, William A. Gamson and Andre Modigliani, The Changing Culture of Affirmative Action, 3 Res in Pol Soc 137, 137-62 (1987); Kluegel, 28 Am Behav Scientist at 775-80 (cited in note 24 ).

${ }^{42}$ For examples of neoconservative work that had been published by the late $1970 \mathrm{~s}$, see Nathan Glazer, Affirmative Discrimination: Ethnic Inequality and Public Policy (Harvard, 1975); Thomas Sowell, Three Black Histories, in Thomas Sowell, ed, American Ethnic Groups 7, 39-40 (Urban Institute, 1978). See generally, Equal Employment Advisory Council, Perspectives on Availability (cited in note 23) (containing a number of articles questioning whether statistical studies can control for pre-labor market differences sufficiently to render them probative of discrimination). For accounts of neoconservative organizing and activities, including challenges to affirmative action, see Jerome L. Himmelstein, To the Right: The Transformation of American Conservatism (California, 1990); Peter Steinfels, The Neo-Conservatives: The Men Who Are Changing America's Politics (Simon and Schuster, 1979).

${ }^{43}$ Kluegel, 28 Am Behav Scientist at 764-65, Table 1 (cited in note 24). See also James R. Kluegel and Eliot R. Smith, Whites' Beliefs About Blacks' Opportunity, 47 Am Soc Rev 518,519 (1982) (reporting that in 1980, 73\% of whites saw 'blacks' opportunity as equal to or greater than the average person in America (assuming that persons work hard)"); James R. Kluegel, Trends in Whites' Explanations of the Black-White Gap in Socioeconomic Status, 1977-89, $55 \mathrm{Am}$ Soc Rev 512, 517 (1990) (showing that the proportion of whites who attribute the Black-white socioeconomic gap to a lack of will or effort on the part of Blacks remained stable between 1977 and 1988-89).

4 Kluegel, 28 Am Behav Scientist at 767, Table 2 (cited in note 24). 
defense may have resonated with the popular tendency to hold minorities responsible for their own economic disadvantage.

\section{B. The Data}

This study draws on a data set of all published Title VII race and sex discrimination cases since 1965 in which a federal district court or court of appeals has addressed the lack of interest defense. ${ }^{45}$ The data set includes decisions addressing the argument that women or minorities failed to apply for the jobs at issue, where the implicit premise of the argument is that they lacked interest in the work..$^{46}$

Because we are examining how courts have responded to the lack of interest argument, we treat as the unit of analysis not the entire case, but rather the specific claim or claims of discrimination against which this argument was asserted. ${ }^{47}$ In addition, because we are comparing how the courts have responded to the lack of interest argument in the race and sex discrimination contexts, we classify the race and sex discrimination claims in mutually ex-

45 Under the senior author's supervision, law students systematically searched for judicial decisions addressing the lack of interest argument in the following two sources: (1) the Fair Employment Practice Cumulative Digests, published by the Bureau of National Affairs, Volumes 1-46; and (2) the West digests, including the Eighth Decennial Digest, Ninth Decennial Digest, the General Digest, Sixth Series, Volumes 1-53, and the General Digest, Seventh Series, Volumes 1-2. Although our search was designed to locate all published decisions in which a federal court addressed the lack of interest argument, we may not have located every such case. Such a failure would raise no methodological problem, however, so long as the search strategy did not yield a biased selection of cases. There is no reason to suspect any such bias. A list of the 117 cases in our data set, with complete citations, is on file with the University of Chicago Law Review.

46 For an example of a case in which an employer's assertion that women failed to apply for a nontraditional job rested on an assumption that women lacked interest in the work, see Dothard v Rawlinson, 433 US 321, 330 (1977), discussed in Schultz, 103 Harv L Rev at 1761-63 (cited in note 20 ).

47 If, for example, the plaintiffs alleged discrimination in both hiring and promotion, but the court addressed the lack of interest argument only in connection with the hiring claim, our data set would include only the hiring claim. By contrast, if the court analyzed the lack of interest argument separately in connection with the hiring and promotion claims, our data set would include each of these claims. Because the evidence presented in connection with the lack of interest argument may be different for different claims (for example, hiring and promotion), it would have been impossible to capture the full range of evidence that influenced outcomes without including each such claim as a separate unit of analysis. Furthermore, it seemed methodologically indefensible to exclude arbitrarily one claim or the other. In any event, only 13 of the cases in our data set involved multiple claims. Plaintiffs' success rates in race and sex discrimination cases are very similar regardless of whether only one or multiple claims are included. 
clusive terms. ${ }^{48}$ We treat a claim as a sex discrimination claim if the employer argued that women (of whatever race) lacked interest in the work because of their gender, and as a race discrimination claim if the employer argued that members of a minority group (of whatever sex) lacked interest in the work because of their race. ${ }^{49}$ Although the data set contains both district court and court of appeals decisions, it includes only the district court or appellate decision for any given claim; in general, we include the final decision that included a clear resolution and substantive analysis of the

\footnotetext{
${ }^{48}$ As our classification scheme makes clear, however, the lack of interest argument poses a potential double risk for women of color. As women, they may confront the argument that they lack interest in male-dominated jobs because of their gender. As minorities, they may confront the argument that they lack interest in predominantly white jobs because of their race. This double risk is particularly unfair, since women of color historically have been relegated to jobs that are less desirable than those available to men of color or white women. See, for example, Jones, Labor of Love, Labor of Sorrow at 134-40, 199-221, 303-04 (cited in note 32); Teresa L. Amott and Julie Matthaei, Race, Gender, and Work: A Multicultural Economic History of Women in the United States 141-91 (South End Press, 1991).

49 If, for example, the plaintiffs alleged both sex and race discrimination in hiring, but the court addressed the lack of interest argument only in connection with the sex discrimination claim (analyzing whether women lack interest in the work), our data set would include only one sex claim. If, on the other hand, the court addressed the lack of interest argument separately in connection with both the sex and race discrimination claims (analyzing whether women lack interest in the work and also whether minorities do), our data set would include both the sex and race claims as separate cases. In a few cases, the plaintiffs alleged both race and sex discrimination and the court did not address the lack of interest argument separately in connection with each of these claims, but simply undertook a combined analysis of whether women and minorities lack interest in the work. Because part of our project involves examining whether there are differences in the courts' responses to the lack of interest argument in the race and sex discrimination contexts, it would have been problematic to include those cases in which the courts by definition failed to distinguish between the two contexts. We therefore excluded them from the data set.
} 
lack of interest defense. ${ }^{.0}$ Overall, our data set includes 117 claims for which courts gave a clear ruling on this defense. ${ }^{\text {sI }}$

Although our data set approximates the universe of all published decisions addressing the lack of interest argument, cases in which employers assert this argument are not necessarily representative of other Title VII disputes. ${ }^{\mathbf{5 2}}$ In addition, almost all of the cases in our data set were resolved after trial, and tried cases may not be a random sample of all filed cases. ${ }^{\text {ss }}$ Finally, all of the cases in our data set were published, and published cases may not be a random sample of all filed or tried cases. ${ }^{54}$

Because we are analyzing how the courts have responded to a defense (the lack of interest defense), however, published decisions rather than all filed cases provide the best source of data for our study. Filed cases not resolved by formal adjudication (particularly cases that settle) are unlikely to contain records that disclose the

so Thus, where a district court's decision was not appealed, or was appealed but was reversed or vacated on grounds unrelated to the lack of interest argument, the district court's resolution of the lack of interest argument was final and we treat the case as having been decided by the district court. Where a district court's decision was appealed, and the appellate opinion included a resolution and a substantive discussion of the merits of the lack of interest argument, the court of appeals' resolution of the argument was final and we treat the case as having been decided by the court of appeals. In a few anomalous cases, the court of appeals apparently affirmed the district court's ruling on the lack of interest argument, but the appellate opinion contained no substantive discussion of the merits of this argument. Because we are investigating the extent to which the courts relied on certain types of evidence and other facts to resolve the lack of interest issue, we treat these cases as having been decided by the district court and we utilize the district court's opinion in our analyses.

s1 Because almost all of our analyses investigate whether the plaintiff or defendant prevailed on the lack of interest argument, we excluded a few cases in which it was unclear from the court's decision which party (if any) prevailed.

52 See note 60 .

ss See, for example, George L. Priest and Benjamin Klein, The Selection of Disputes for Litigation, $13 \mathrm{~J}$ Legal Stud 1 (1984). Of course, even filed lawsuits are only a small portion of actionable grievances that might have been brought to the legal system. See William L.F. Felstiner, Richard L. Abel, and Austin Sarat, The Emergence and Transformation of Disputes: Naming, Blaming, Claiming . . . , 15 L \& Soc Rev 631, 636 (1980-81); David M. Trubek, et al, The Costs of Ordinary Litigation, 31 UCLA L Rev 72, 85-87 (1983). There is evidence that people who experience employment discrimination are less likely to take actions to vindicate their rights than people with other types of grievances. See Barbara A. Curran, The Legal Needs of the Public 141-42, 146, 262 (American Bar Foundation, 1977); Samborn, Natl L J 1 (Jul 16, 1990) (cited in note 38); see also Richard E. Miller and Austin Sarat, Grievances, Claims and Disputes: Assessing the Adversary Culture, $15 \mathrm{~L}$ \& Soc Rev 525, 537, 544-45 (1980-81) (reporting the same result for people who experience discrimination generally).

s4 See, for example, Susan M. Olson, Studying Federal District Courts Through Published Cases: A Research Note, 15 Justice System J 782 (1992); Peter Siegelman and John J. Donohue, Studying the Iceberg From its Tip: A Comparison of Published and Unpublished Employment Discrimination Cases, 24 L \& Soc Rev 1133 (1990). 
defenses the employer intended to assert. Even if the records for some non-adjudicated cases revealed the employers' contemplated defenses, the records would be unlikely to disclose the full range of relevant facts and evidence. ${ }^{55}$ Furthermore, even if the records for such cases disclosed the planned defenses and evidence, they would not reveal the presiding judge's reactions to the evidence and other case characteristics. For these reasons, cases adjudicated on the merits are the only group of cases likely to contain the information we seek..$^{56}$

In light of the possibility that the decisions in our data set may be unrepresentative, we compare them to a second data set comprised of a sample of a closely-matched group of filed cases. Because the published decisions in our data set include only cases in which the lack of interest defense was actually raised and resolved, it is useful to have as a baseline the underlying group of all filed cases in which this defense might have been raised. To create such a baseline, we utilized the American Bar Foundation's ("ABF") random sample of 1,247 employment discrimination cases

so See Janet Cooper Alexander, Do the Merits Matter? A Study of Settlements in Securities Class Actions, 43 Stan L Rev 497, 506 n 24 (1991) ("Settlement agreements typically contain confidentiality provisions restricting the disclosure of discovery material. Moreover, important facts or their implications often are not contained in discovery materials, though they are known to one or both sides and would be material to the outcome."); Richard L. Marcus and Edward F. Sherman, Complex Litigation 531 (West, 1985) (observing that defendants often "insist upon entry of a protective order with regard to material they previously produced through discovery as part of a negotiated settlement package").

${ }^{\circ 8}$ Among employment discrimination cases, cases with published opinions are far more likely than unpublished cases to include cases that were adjudicated on the merits (through trial, motion for summary judgement, or motion to dismiss for failure to state a claim), as opposed to cases that were settled, dropped, or dismissed for procedural reasons. See Siegelman and Donahue, $24 \mathrm{~L} \&$ Soc Rev at 1155 (cited in note 54). Consequently, published decisions are the most direct source of data for our study.

Even though published cases may not be representative of all filed cases, published decisions nonetheless have an important influence on the outcomes of filed cases. Because published decisions are more readily accessible than unpublished ones, lawyers and advocates rely on them heavily in negotiating settlement agreements, evaluating the strength of potential cases, and, more broadly, advising clients and constituents of their legal rights. See, Susan W. Brenner, On Publication and Precedent: An Inquiry Into the Ethnomethodology of Case Reporting in the American Legal System, 39 DePaul L Rev 461, 500-06 (1990); Marc Galanter, Conceptualizing Legal Change and its Effects: A Comment on George Priest's "Measuring Legal Change," $3 \mathrm{~J} \mathrm{~L} \mathrm{Econ} \mathrm{\&} \mathrm{Org} \mathrm{235,} 240$ (observing that lawyers must rely on "conventional legal interpretation," because they have only limited information about settlements). Thus, published decisions addressing the lack of interest argument help establish the formal legal framework within which workers not involved in the immediate legal contest will understand and bargain with their employers about job segregation in the future. 
filed in federal district courts in seven districts. ${ }^{57}$ We sorted this ABF data set into the subset of filed Title VII cases in which employers are most likely to assert the lack of interest argument: class action cases alleging race or sex discrimination in hiring, transfer, promotion, and other employment practices directly associated with job segregation..$^{58}$ Due to the dramatic decline in Title VII class action filings since the late $1970 \mathrm{~s},{ }^{59}$ this sorting process reduced the number of cases in the ABF data set substantially, to seventy-seven cases for the entire period. ${ }^{\circ 0} \mathrm{We}$ refer to this resultant data set as the "ABF sample." Although our data set and the ABF sample differ in some respects, ${ }^{61}$ the ABF sample provides a reasonable approximation of the set of filed cases in which the lack

37 From a complete listing of all federal employment discrimination cases filed between 1972 and 1987 and compiled by the Administrative Office of the U.S. Courts under Code 442 (Civil Rights, Employment) American Bar Foundation researchers collected data on a random sample of 1,247 cases filed in federal district court in seven districts. See Siegelman and Donohue, $24 \mathrm{~L} \&$ Soc Rev at $1136 \mathrm{n} 6$ (cited in note 54). The seven judicial districts and corresponding cities included in the ABF sample are the Southern District of New York (New York); the Northern District of Illinois (Chicago); the Eastern District of Pennsylvania (Philadelphia); the Northern District of California (San Francisco); the Northern District of Texas (Dallas); the Northern District of Georgia (Atlanta); and the Eastern District of Louisiana (New Orleans). Id at 1136 n 7, 1143.

ss In our own data set, almost all of the cases alleged Title VII violations (although some cases also alleged violations of other statutory or constitutional provisions). In addition, all but a few of the cases alleged discrimination in recruiting, hiring, assignment, transfer, promotion, and other employment practices directly associated with job segregation. (In three anomalous cases, the plaintiffs alleged discrimination in discharge, union organizing, or training.) Finally, $88.0 \%$ of our cases alleged classwide claims of discrimination as opposed to individual claims. The predominance of classwide claims among cases addressing the lack of interest defense is not surprising. The lack of interest argument is used to challenge plaintiffs' statistical evidence, and plaintiffs are most likely to present statistical evidence in connection with classwide claims of discrimination.

so For documentation of this decline, see John J. Donohue and Peter Siegelman, The Changing Nature of Employment Discrimination Litigation, 43 Stan L Rev 983, 1019-21 (1991).

60 Of the 1,247 cases in the original ABF data set, 941 alleged Title VII violations; of these 941 cases, 508 involved employment practices associated with job segregation; of these 508 cases, 418 alleged either race (including national origin) or sex discrimination; and of these 418 cases, 77 involved class actions. Overall, the sorting process reveals that classwide claims alleging discrimination in hiring or other employment practices associated with job segregation constitute only around $8.2 \%$ of all filed Title VII cases (77 out of 941 ). This figure underscores the fact Title VII cases involving the lack of interest argument may not be representative of all filed Title VII cases.

61 As noted above, the ABF data set includes cases filed from July 1, 1972, through March 31, 1987, whereas our data set includes cases decided from 1967 through 1989. In addition, the ABF data set includes only cases filed in federal district court, whereas our data set includes decisions published by federal district courts and courts of appeals. Finally, in the ABF data set the unit of analysis is the entire case, whereas in our data set the unit of analysis is the individual claim against which the lack of interest defense was asserted. 
of interest argument was a possible defense. Where appropriate, we compare the cases in our data set to the cases in the ABF sample. In light of the small number of cases in the ABF sample, however, we reach only tentative conclusions from these comparisons.

Because we are interested in determining whether the courts' responses to the lack of interest argument changed over time, our analyses control for the period in which the case was decided. For a number of reasons, we treat 1977 as the central dividing point. In 1977, the Supreme Court decided three important cases which addressed the lack of interest argument for the first time. ${ }^{62}$ In these decisions, the Court defined the lack of interest issue as a factual question to be resolved by the trial courts, ${ }^{63}$ and stressed that trial judges should examine this issue and scrutinize plaintiffs' statistical evidence with care. ${ }^{64}$ Rhetorically at least, the Court's decisions signalled a departure from earlier courts of appeals decisions, which had emphasized the power of statistical proof and expressed skepticism about whether minorities' lack of interest in higherpaying employment could ever suffice to explain patterns of racial segregation on the job. To the extent that the Court was retreating from the appellate courts' more liberal approach, this retreat may have been part of a larger trend in employment discrimination law. Between 1976 and 1978, the Supreme Court issued a number of decisions that were unfavorable to employment discrimination plaintiffs. ${ }^{65}$ Indeed, according to many scholars, this period represented a turning point in Title VII doctrine (and civil rights law

${ }^{62}$ These cases are Int'l Brotherhood of Teamsters v United States, 431 US 324 (1977); Dothard $v$ Rawlinson, 433 US 321 (1977); and Hazelwood School District v United States, 433 US 299 (1977). For a detailed discussion of how the Supreme Court addressed the lack of interest issue in these cases, see Schultz, $103 \mathrm{Harv} L \mathrm{Rev}$ at 1759-65 (cited in note 20).

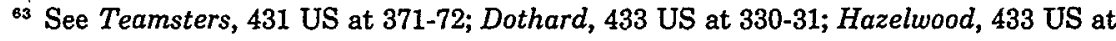
311-13.

64 In Teamsters, the Court stated: "We caution only that statistics are not irrefutable; they come in infinite variety and, like any other kind of evidence, they may be rebutted. In short, their usefulness depends on all of the surrounding facts and circumstances." 431 US at 340 . In Hazelwood, the Court reversed and remanded to the trial court for a more precise delineation of the relevant labor market and the resulting statistical disparity. In connection with the specification of the relevant labor market, the Court directed the trial judge to consider carefully Hazelwood's position that the neighboring city school district's affirmative action efforts had diverted to the city a disproportionate number of Black teachers who might otherwise have been interested in Hazelwood. 433 US at 310-13. Even in Dothard, in which the Court affirmed the lower court's holding that plaintiffs' statistical proof sufficed to make a prima facie case of disparate impact, the Court emphasized that the State had introduced no evidence to undermine the plaintiffs' statistics: "If the employer discerns fallacies or deficiencies in the data offered by the plaintiff, he is free to adduce countervailing evidence of his own. In this case no such effort was made." 433 US at 331.

Gs See note 40 . 
generally), which ushered in a modern era of more burdensome standards of proof for plaintiffs. ${ }^{68}$ Thus, distinguishing cases decided before and after 1977 helps to locate any shifts that may have occurred in the lower courts' treatment of the lack of interest argument.

C. The Frequency and Success of the Lack of Interest Defense in Race and Sex Discrimination Cases Over Time

Our analyses reveal some important differences in the sequencing and success of the lack of interest defense in race and sex discrimination cases over time. Table 1 shows the distribution of race and sex discrimination cases, before and after 1977, for the published decisions in our data set and the filed cases in the ABF sample. Although we describe the two time periods as 1967-77 and 1978-89 to reflect the periods covered by our data set, the ABF sample actually begins in 1972 and ends in $1987 . .^{67}$ For convenience, we refer to the cases in our data set as "published lack of interest cases" and to the cases in the ABF sample as "potential lack of interest cases."

TABLE 1: Frequency of Published Cases Addressing the Lack of Interest Defense and Filed Cases in the ABF Sample, By Race and Sex Over Time

\begin{tabular}{lllllllll}
\hline Period & \multicolumn{3}{c}{ Race } & \multicolumn{3}{c}{ Sex } \\
\hline & $\begin{array}{l}\text { Published } \\
\text { Lack of }\end{array}$ & \multicolumn{2}{c}{ Potential } & \multicolumn{2}{l}{ Published } & \multicolumn{2}{l}{ Potential } \\
& $\begin{array}{l}\text { Lack of } \\
\text { Interest Cases }\end{array}$ & \multicolumn{2}{l}{ Interest Cases } & $\begin{array}{l}\text { Lack of } \\
\text { Interest Cases }\end{array}$ & \multicolumn{2}{l}{ Lack of } \\
Interest Cases \\
$1967-1977$ & $68.3 \%$ & $(43)$ & $75.0 \%$ & $(45)$ & $20.4 \%$ & $(11)$ & $64.7 \%$ & $(11)$ \\
$1978-1989$ & $31.7 \%$ & $(20)$ & $25.0 \%$ & $(15)$ & $79.6 \%$ & $(43)$ & $35.3 \%$ & $(6)$ \\
\hline $1967-1989$ & $100 \%$ & $(63)$ & $100 \%$ & $(60)$ & $100 \%$ & $(54)$ & $100 \%$ & $(17)$ \\
\hline
\end{tabular}

so Id.

67 The difference in the time periods covered by our data set and the ABF data set do not change the basic patterns reported in Table 1 . There are no race discrimination cases after 1987 in our data set. If all the race discrimination cases decided before 1972 were excluded from our data set, the distribution of race discrimination cases would decline to $60.8 \%$ in the $1972-77$ period and increase to $37.3 \%$ in the $1977-87$ period. Similarly, there are no sex discrimination cases before 1972 in our data set. If all the sex discrimination cases decided after 1987 were excluded from our data set, the distribution of sex discrimination cases would increase to $21.6 \%$ in the $1972-77$ period and decline to $78.4 \%$ in the 1977 87 period. 
Columns two and four reveal a major difference in the time trends for published race and sex discrimination cases addressing the lack of interest argument: the race discrimination cases are concentrated in the 1967-77 period, while sex discrimination cases are concentrated in the more recent $1978-89$ period. For race discrimination cases, the trend in the distribution of published cases over time parallels the distribution of filed cases. In our data set, courts decided 68.3 percent of the race discrimination cases between 1967 and 1977, and 31.7 percent between 1978 and 1989. Similarly, in the ABF sample, race discrimination cases decreased dramatically after 1977 , with only 25 percent of all cases filed after that year. ${ }^{68}$ These patterns reflect larger trends for employment discrimination cases, in which class action and hiring discrimination case filings plunged dramatically in the late 1970s. ${ }^{69}$ Thus, the decline evidenced in column two signals that potential race discrimination plaintiffs have stopped filing the class action challenges to job segregation in which employers are likely to raise the lack of interest defense, not that employers have stopped asserting this defense.

For sex discrimination cases, the distribution of published lack of interest cases in our data set does not mirror that of potential lack of interest cases in the ABF sample. In our data set, courts decided only 20.4 percent of the sex discrimination cases in the 1967-77 period, and 79.6 percent in the 1978-89 period. In the $A B F$ sample, by contrast, the sex discrimination cases follow the same general trend as the race discrimination cases: the vast majority were filed before 1978. Thus, sex discrimination cases raising the lack of interest argument are underrepresented in the early to mid 1970 s and overrepresented in the late 1970s and 1980s. This pattern may suggest that in sex discrimination cases, employers began to resort to the lack of interest defense more frequently after 1977.

Just as the time trends differ for published race and sex discrimination cases addressing the lack of interest argument, the trends in success rates also differ for the two groups of cases. Table 2 shows plaintiffs' success rates in the race and sex discrimination cases in our data set for the 1967-77 and 1978-89 periods. This

e8 In addition, more refined analyses (not shown in Table 1) reveal that in both our data set and the ABF sample, race discrimination cases slowed to a halt after 1983. Our search for published cases addressing the lack of interest defense located only one race discrimination case decided after 1983 , a mere $1.6 \%$ of the total group of published race cases. Similarly, in the ABF sample, only one race discrimination case was filed after 1983, a mere $1.7 \%$ of the total group of filed race cases.

${ }^{69}$ See Donohue and Siegelman, 43 Stan L Rev at 1015-16, 1019-20 (cited in note 59). 
analysis defines "success" to mean that plaintiffs persuaded the court to reject the lack of interest argument. Additional analyses show, however, that prevailing on the interest argument is virtually tantamount to prevailing on the underlying claim of discrimination. ${ }^{70}$ Thus, the results in Table 2 would be similar if success were defined to mean that plaintiffs prevailed on the underlying claim. ${ }^{71}$

TABLE 2: Plaintiffs' Success Rates in Cases Addressing the Lack of Interest Defense, By Race and Sex Over Time

\begin{tabular}{lllll}
\hline Period & \multicolumn{2}{c}{ Race } & \multicolumn{2}{c}{ Sex } \\
\hline $1967-1977$ & $86.0 \%$ & $(37 / 43)$ & $54.5 \%$ & $(6 / 11)$ \\
$1978-1989$ & $40.0 \%$ & $(8 / 20)$ & $58.1 \%$ & $(25 / 43)$ \\
\hline $1967-1989$ & $71.4 \%$ & $(45 / 63)$ & $57.4 \%$ & $(31 / 54)$ \\
\hline
\end{tabular}

Two striking patterns emerge from this analysis. First, in the 1967-89 period as a whole, plaintiffs have been far more likely to prevail on the lack of interest argument in race discrimination cases than in sex discrimination cases. Plaintiffs persuaded courts to reject this argument in 71.4 percent of all race cases, but in only 57.4 percent of all sex cases. This disparity is largely attributable to the earlier period, for after 1977 sex discrimination plaintiffs experienced similar or even somewhat greater success than race discrimination plaintiffs on the lack of interest argument. Additional analyses (not shown in the table) reveal that in the 1978-83 period, plaintiffs' success rates in race and sex discrimination cases were

70 Among both the race and sex discrimination cases, there was not a single case in which the party who lost on the lack of interest argument prevailed on the underlying claim. In race discrimination cases, plaintiffs won on the underlying claim in $75.6 \%$ (34 out of 45) of the cases in which they won on the lack of interest argument, and defendants won on the underiying claim in $83.3 \%$ (15 out of 18) of the cases in which they won on this argument; in all other cases, neither party clearly prevailed on the underlying claim. Similarly, in sex discrimination cases, plaintiffs won on the underlying claim in $83.9 \%$ (26 out of 31 ) of the cases in which they won on the lack of interest argument, and defendants won on the underlying claim in $87.0 \%$ (20 out of 23 ) of the cases in which they won on the argument; in all other cases, neither party prevailed on the underlying claim. For both race and sex cases, the association between success on the lack of interest argument and success on the underlying claim is highly significant ( $p$-value $=.00$ for both sets of cases).

"I In race discrimination cases, plaintiffs' success rate would be $87.5 \%$ in the 1967-1977 period, $35.3 \%$ in the $1978-1989$ period, and $69.4 \%$ in both periods combined. Similarly, in sex discrimination cases, plaintiff's' success rate would be $60.0 \%$ in the $1967-1977$ period, $55.6 \%$ in the $1978-1989$ period, and $56.5 \%$ in both periods combined. 
roughly equivalent; in the $1984-89$ period, there are too few race discrimination cases to permit comparison. ${ }^{22}$

The second, and perhaps even more striking trend, is that race discrimination plaintiffs have become substantially less likely to prevail on the lack of interest argument since the late 1970s. In the 1967-77 period, race discrimination plaintiffs experienced near universal success, persuading courts to reject the lack of interest defense in 86 percent of all cases. In the 1978-89 period, by contrast, plaintiffs prevailed in only 40 percent of the cases. More refined analyses disclose that plaintiff's' success rate plummeted around 1978, and declined steadily thereafter..$^{73}$ This sharp drop-off followed by a steady decline contrasts with the pattern for sex discrimination cases, in which plaintiffs' success rates remained relatively stable before and after 1978 (and even increased between 1984 and 1989).

To place these two patterns in context, it would be useful to be able to determine whether they hold for the ABF sample. Unfortunately, the numbers of tried cases in the ABF sample are too small to permit meaningful comparison. ${ }^{74}$ It is less helpful to refer to other studies of employment discrimination for comparison, because they examine cases that are very different from the class action challenges to job segregation in which the lack of interest argument is most likely to be raised. Nonetheless, the decline in plaintiffs' success rates in the race discrimination cases in our data set does not appear to be inconsistent with the patterns reported

72 In the $1978-83$ period, plaintiffs won $42.1 \%$ ( 8 out of 19 ) of the race discrimination cases, and $48.3 \%$ (14 out of 29 ) of the sex discrimination cases. In the 1984-89 period, there was only one race discrimination case, which plaintiffs lost. Plaintiffs' success rate increased substantially in sex discrimination cases, however, to $78.6 \%$ (11 out of 14 cases). Although these data raise the possibility that the courts began to treat sex discrimination plaintiffs more favorably than race discrimination plaintiffs after 1983 , there are simply too few race discrimination cases to permit meaningful comparison.

73 Between 1975 and 1977 , race discrimination plaintiffs won an overwhelming $90.9 \%$ of their cases. In the $1978-80$ period, this figure fell precipitously to only $54.5 \%$, and in the 1981-83 period, it fell to $25 \%$. After 1983 , there was only one race discrimination case, and plaintiffs lost.

74 In the ABF sample, there were only seven race discrimination cases tried before 1978 , and only one race case tried thereafter. There was only one sex discrimination case tried before 1978, and only one sex case tried thereafter. Nonetheless, in this small ABF sample, the same two trends emerge as in our data set. First, plaintiffs' success rates were lower in sex discrimination cases than in race discrimination cases: plaintiffs won $25 \%$ ( 2 out of 8 ) of the race discrimination cases that reached trial, but they won $0 \%$ (0 out of 2 ) of the sex discrimination cases that reached trial. Second, plaintiffs' success rate declined in race discrimination cases over time: between 1972 and 1977 , plaintiffs won $28.6 \%$ (2 out of 7) of the race discrimination cases that reached trial, but between 1978 and 1987, plaintiffs won none ( 0 out of 1 ) of the race discrimination cases that reached trial. 
in other studies. In a study of all published federal appellate employment discrimination cases decided between 1965 and 1985, for example, Burstein found that race discrimination plaintiffs' success rates declined between 1965-75 and 1976-85. ${ }^{75}$ In another study of all race-based intentional discrimination cases tried in federal district courts between 1976 and 1988, Eisenberg and Johnson found that plaintiffs prevailed in 40 percent-a figure identical to our 40 percent success rate for race discrimination plaintiffs after $1978 .{ }^{76}$ Researchers have also reported success rates for sex discrimination cases that parallel those in our data set. In Burstein's study, for example, sex discrimination plaintiffs prevailed in 58 percent of their cases, a figure almost identical to the 57 percent success rate in our cases. ${ }^{77}$ On the other hand, the only two other studies that have compared success rates for race- and sex-based employment discrimination cases have not reported lower rates for sex discrimination cases. ${ }^{78}$ These findings may suggest that the decline in race discrimination plaintiffs' success rates in our data set is indicative of a larger trend for Title VII cases, while the disparity between race and sex discrimination plaintiffs' success rates is unique to

7s See Paul Burstein, Legal Mobilization as a Social Movement Tactic: The Struggle for Equal Employment Opportunity, 96 Am J Soc 1201, 1214, 1215 (1991) (reporting that race discrimination plaintiffs' success rates in published federal appellate cases declined from $77 \%$ in the Johnson administration, to $62 \%$ in the Nixon and Ford administrations, to $53 \%$ and $54 \%$ in the Carter and Reagan administrations, respectively).

${ }^{76}$ See Theodore Eisenberg and Sheri Lynn Johnson, The Effects of Intent: Do We Know How Legal Standards Work? 76 Cornell L J 1151, 1172 (1991).

77 See Burstein, $96 \mathrm{Am}$ J Soc at 1215 (cited in note 75). See also Karen O'Connor and Lee Epstein, Sex Discrimination and the Supreme Court: An Analysis of Judicial Support for Gender-Based Claims, 64 Soc Sci Q 327, 328 (1983) (reporting that plaintiffs won 58.8\% of all cases alleging any type of sex discrimination decided by the Supreme Court between 1969 and 1981); Ronald Stidham, Robert A. Carp and C. K. Rowland, Women's Rights Before the Federal District Courts, 1971-1977, 11 Am Pol Q 205, 207-08 (1983) (reporting that plaintiffs prevailed in $51 \%$ of all cases alleging any type of sex discrimination decided by the federal district courts and published in the Federal Supplement between 1971 and 1977). But see Trudy Mills, On the Use of Equal Employment Laws, 24 Pac Soc Rev 196, 206 (1981) (reporting that plaintiffs won only $32 \%$ of all cases alleging sex discrimination in employment decided by federal district courts in five circuits and published in the Fair Employment Practices reporter between 1967 and 1975).

${ }^{78}$ In Burstein's study of published federal appellate employment discrimination cases, plaintiffs had identical success rates in race and sex discrimination cases (58\%) for the overall 1965-1985 period. See Burstein, $96 \mathrm{Am}$ J Soc at 1215 (cited in note 75). In Schwab and Eisenberg's study of all federal civil rights cases filed in three judicial districts during 1981, Title VII plaintiffs had higher success rates in sex discrimination cases than in race discrimination cases. See Stewart Schwab and Theodore Eisenberg, The Influence of Judicial Background on Settling and Winning Cases and A Study of the Disputing Pyramid 18-19 (on file with U Chi L Rev). Given that Schwab and Eisenberg's study examines Title VII cases filed in only one year, however, their finding is not necessarily inconsistent with ours. 
cases addressing the lack of interest defense or to cases challenging job segregation.

The lower success rates in sex discrimination cases in our data set may suggest that, overall, the courts have treated sex discrimination plaintiffs less favorably than race discrimination plaintiffs in connection with the lack of interest argument. Similarly, the decline in plaintiffs' success rates in more recent race discrimination cases seems to suggest that since 1978 , the courts have responded less favorably to race discrimination plaintiffs in connection with this argument. These two hypotheses are consistent with commentators' observations that the courts have tended to treat sex discrimination less seriously than race discrimination, and that the courts have been less sympathetic to complaints of race discrimination since the late 1970s. Nonetheless, as we explain below, there are reasons to be cautious in drawing conclusions about judicial attitudes from differences in success rates alone. Section II examines the first trend, drawing on quantitative analyses of the race and sex discrimination cases to evaluate alternative explanations for sex discrimination plaintiffs' lower overall success rate. Section III analyzes the second trend, using similar methods to account for the lower success rates in modern race discrimination cases.

\section{The Double Standards for Interpreting Race and Sex} SEgregation on the Job: Judicial Responses to THE Lack of Interest Defense in Race and Sex Discrimination Cases, 1967-1989

A. Alternative Theoretical Explanations for the Difference in Success Rates

Sex discrimination plaintiffs may have experienced lower success rates than race discrimination plaintiffs during the 1967-89 period for two different reasons. If judges held culturally biased attitudes about women's work aspirations, they may have been more predisposed to accept the lack of interest defense in sex discrimination cases than in race discrimination cases. As a result, judges may have imposed more difficult standards of proof for refuting the lack of interest argument on sex discrimination plaintiffs. If sex discrimination plaintiffs generally presented evidence and facts that provided as strong a basis for rejecting the lack of interest argument as race discrimination plaintiffs, the fact that sex discrimination plaintiffs experienced less success on this argument would suggest that the courts have treated them less favorably. On the other hand, one cannot infer that judges responded 
with such bias without first comparing the relative strength of the sex and race discrimination cases. Judges may have applied the same legal standards for evaluating the lack of interest defense in both types of cases, but the sex discrimination plaintiffs simply presented weaker evidence and facts under these uniform standards. If so, they would have experienced lower success rates. We refer to these two explanations as the "judicial bias" and "weaker evidence" theories, respectively.

The weaker evidence theory poses a provocative question: Why would the sex discrimination cases have been weaker, in the aggregate, than the race discrimination cases in our data set? The literature suggests two potential explanations.

\section{Underlying activity.}

The first explanation focuses on the relationship between the "underlying activity" that generates charges of discrimination and the strength of the evidence introduced in litigated cases. It is not contained in a formal model, but derives instead from the notion that litigation reflects underlying social realities. ${ }^{79}$ According to this explanation, employers may have been less likely to discriminate-or less likely to discriminate in a blatant, obvious fashion-against women than against minorities in connection with hiring and other employment practices associated with job segregation. As a result, the sex discrimination cases may have had weaker evidence and facts than the analogous group of race discrimination cases. If this were true, sex discrimination plaintiffs would have been less likely to prevail on the lack of interest argument than race discrimination plaintiffs, even if judges were applying the same legal standards to evaluate this argument in both sets of cases.

Analytically, however, this explanation may be inadequate. As twenty years of research on the disputing process has established,

between litigation and the underlying activity lies a complex structure of disputing activity, in which grievances are perceived, disputes constructed and transformed, resources or-

79 See Marc Galanter, Case Congregations and Their Careers, 24 L \& Soc Rev 371, 37374 (1990) (discussing the "intuitively plausible notion" that there is a correlation between the volume of an underlying activity and the volume of filed and litigated cases arising out of that activity); Burstein, $96 \mathrm{Am}$ J Soc at 1209 (cited in note 75) (drawing on the "underlying activity" hypothesis to suggest that the volume of employment discrimination cases should reflect "the incidence of activities prohibited by the law ... the size of the group and the pervasiveness of discrimination its members face"). 
ganized and rationed, and so forth .... [M]any factors [] mediate the relationship so that litigation is not a mere reflection of underlying activity..$^{80}$

Even if sexually discriminatory employment practices were less prevalent or less blatant than racially discriminatory practices during the period under consideration, this would not necessarily mean that filed or litigated sex discrimination cases would have been weaker than the corresponding group of race discrimination cases. If, for example, victims of sex discrimination were less likely than victims of race discrimination to perceive equivalent work situations as discriminatory or were less likely to be organized to initiate litigation, ${ }^{81}$ they may have filed sex discrimination suits only in circumstances involving facts and evidence that were as strong as those involved in the average race discrimination suit. The extent or egregiousness of discrimination in the economy as a whole may not correlate directly with the strength of discrimination cases that are filed or brought to trial.

The underlying activity explanation also rests on questionable empirical assumptions. Although it is difficult to estimate the extent or egregiousness of discrimination, the assumption that sexually discriminatory practices have been less prevalent than racially discriminatory practices over the past twenty-five years is open to serious doubt. Researchers typically estimate the extent of job segregation with a construct called the index of segregation, which measures the proportion of workers who would have to switch to occupations atypical for their race or sex in order for occupations to become racially or sexually integrated..$^{82}$ Studies using this index show that since Title VII's enactment, the degree of job segregation by sex has been greater than the degree of job segregation by race. ${ }^{83}$ In 1965 , for example, the index of sex segregation was ap-

${ }^{80}$ Galanter, 24 Law \& Soc Rev at 375-76 (cited in note 79). For examples of this literature, see Felstiner, Abel and Sarat, $15 \mathrm{~L} \&$ Soc Rev 631 (cited in note 53); Miller and Sarat, $15 \mathrm{~L} \&$ Soc Rev 525 (cited in note 53). For a summary, see Marc Galanter, Adjudication, Litigation, and Related Phenomena, in Leon Lipson and Stanton Wheeler, eds, Handbook of Law and the Social Sciences 151 (Russell Sage, 1986).

81 See Burstein, 96 Am J Soc 76, at 1210-12 (cited in note 75) (suggesting that the dearth of sex discrimination complaints relative to race discrimination complaints filed in the early years of Title VII enforcement is attributable to the fact that women are less likely to perceive discrimination and less likely to be organized to initiate litigation).

${ }^{82}$ See Otis Dudley Duncan and Beverly Duncan, A Methodological Analysis of Segregation Indexes, 20 Am Soc Rev 210 (1955).

${ }^{83}$ See Barbara Reskin and Patricia Roos, Job Queues, Gender Queues: Women's Inroads into Male Occupations 5-6 (Temple, 1990); Barbara F. Reskin and Heidi I. Hartmann, eds, Women's Work, Men's Work: Sex Segregation on the Job 19 (National Acad- 
proximately 58.8 percent, while the index of racial segregation was 38.0 percent; by 1981 , the index of sex segregation had declined only slightly to 52.6 percent, while the index of racial segregation had fallen to 20.4 percent. ${ }^{84}$ These and other studies suggest that sex discrimination has been no less pervasive than race discrimination in employment. ${ }^{85}$

Although it is possible that the systems of racial stratification were more overt-and therefore led to more powerful, clear-cut cases of discrimination-this explanation, too, seems doubtful. Certainly, employers have had open and notorious systems of racial exclusion and segregation that relegated African Americans and other minorities to menial jobs. ${ }^{86}$ Yet, the evidence shows that employers have used similarly overt systems of segregation to relegate women (of all races) to undesirable jobs. ${ }^{87}$ Indeed, state law provided institutionalized support for sex segregation in employment. Four years after Title VII's enactment, twenty-six states had laws that prohibited women from working in certain occupations or jobs; forty-one states and the District of Columbia restricted women's hours of work; eighteen states and Puerto Rico prohibited or limited women's night work; eleven jurisdictions imposed weight lifting restrictions on women; and six states prohibited women from working before and after childbirth. ${ }^{88}$ Thus, the claim that sexually discriminatory practices have been less overt or blatant than racially discriminatory practices related to job segregation seems to lack empirical support.

emy, 1986); Albelda, 39 Indus \& Lab Rel Rev at 405-06 (cited in note 2); Beller, Trends at 20 (cited in note 2 ).

s4 See Albelda, 39 Indus \& Lab Rel Rev at 405 (cited in note 2).

ss See Burstein, $96 \mathrm{Am}$ J Soc at 1210 (cited in note 75); Glen Cain, The Economic Analysis of Labor Market Discrimination, in The Handbook of Labor Economics 693-785 (Worth-Holland, 1986).

${ }^{86}$ See, for example, Herbert Hill, Black Labor and the American Legal System: Race, Work and the Law (BNA, 1977); Blumrosen, 6 Indus Rel L J at 342 (cited in note 37); Blumrosen, 22 Rutgers $L$ Rev at 471 (cited in note 4).

${ }_{87}$ The evidence of overt discrimination against women workers is voluminous. For examples, see Barbara R. Bergmann, The Economic Emergence of Women 82-114 (Basic Books, 1986); William T. Bielby and James N. Baron, Men and Women at Work: Sex Segregation and Statistical Discrimination, 91 Am J Soc 759, especially 794-95 (1986) (listing employers' policies).

${ }^{88}$ See US Dept of Labor, Women's Bureau, 1969 Handbook on Women Workers 270-79 (GPO, 1969). For additional information about restrictive labor legislation for women, see Judith A. Baer, The Chains of Protection: The Judicial Response to Women's Labor Legislation (Greenwood, 1978); US Dept of Labor, Women's Bureau, Summary of State Labor Laws for Women 13-14 (GPO, 1965); Pauli Murray and Mary O. Eastwood, Jane Crow and the Law: Sex Discrimination and Title VII, 34 Geo Wash L Rev 232, 248-253 (1965). 


\section{Selection effects.}

The literature on the selection of disputes for litigation provides a second set of explanations for why the sex discrimination cases in our data set may have been weaker than the race discrimination cases. According to this literature, even if the underlying group of filed race and sex discrimination cases were of equal merit, different factors may have governed the selection of the race and sex discrimination cases for litigation. As a result, the litigated sex discrimination cases may have been weaker than the race discrimination cases. To understand how this result could occur, a simplified description of the dominant models of the litigation selection process is necessary.

Although there are a number of formal models that vary in scope and complexity, ${ }^{89}$ most theories start from the premise that filed cases are more likely to go to trial when the parties have differing expectations as to the probable outcome.90 If the parties have equal stakes in the litigation and equal ability to predict the outcome, then neither objectively strong nor objectively weak cases will tend to reach trial. Because the parties will tend to agree on the probable outcomes of objectively strong and objectively weak cases, they will save costs by settling before trial. Consequently, the cases that are most likely to wind up in court are "close" cases in which the parties tend to disagree about the probable outcome. ${ }^{91}$ In fact, Priest and Klein's model predicts that in cases in which the above conditions are met, the plaintiffs' success rate will converge to fifty percent, regardless of the favorableness or unfavorableness of the applicable legal standard..$^{22}$

\footnotetext{
89 We do not attempt to account for more technical selection effects models that address such complexities as strategic bargaining and legal cost allocation. For examples of such models, see Lucian Arye Bebchuk, Litigation and Settlement under Imperfect Information, 15 Rand J Econ 404 (1984); Barry Nalebuff, Credible Pretrial Negotiation, 18 Rand J Econ 198 (1987); and Steven Shavell, Suit, Settlement and Trial: A Theoretical Analysis Under Alternative Methods for the Allocation of Legal Costs, $11 \mathrm{~J}$ Legal Stud 55 (1982).

${ }^{\text {s0 }}$ The most prominent of these models is the one developed by Priest and Klein. See Priest and Klein, $13 \mathrm{~J}$ Legal Stud 1 (cited in note 53). For a comprehensive review of selection models, see Robert D. Cooter and Daniel L. Rubinfeld, Economic Analysis of Legal Disputes and Their Resolution, $27 \mathrm{~J}$ Econ Lit 1067 (1989). For articles questioning whether the uncertainty reflected in differing expectations fuels litigation to the extent suggested by most selection models, see Theodore Eisenberg, Commentary on "On the Nature of Bankruptcy": Bankruptcy and Bargaining, $75 \mathrm{Va} L \mathrm{Rev} 205,209-11$ (1989); Peter H. Schuck, The Role of Judges in Settling Complex Cases: The Agent Orange Example, $53 \mathrm{U}$ Chi L Rev 337, 346 n 30, 352-53 (1986).

${ }^{91}$ See Priest and Klein, $13 \mathrm{~J}$ Legal Stud at 12-17 (cited in note 53); George L. Priest, Measuring Legal Change, 3 J L Econ \& Org 193, 199-200 (1987).

${ }^{92}$ See Priest and Klein, $13 \mathrm{~J}$ Legal Stud at 17-20.
} 
In cases in which the parties' stakes or predictive abilities systematically differ, however, Priest and Klein predict that success rates will deviate from fifty percent. ${ }^{93}$ Where defendants have systematically greater stakes in the litigation than plaintiffs, for example, the success rate will drop below fifty percent. Defendants will in general offer more to settle such cases, but will offer relatively more to settle cases that are strong for plaintiffs and relatively less to settle cases that are weak for plaintiffs, leaving for litigation a biased sample of weaker cases in which plaintiffs are less likely to win..$^{94}$ Where defendants' attorneys have a superior ability to predict case outcomes than plaintiffs' attorneys, similar results will occur. ${ }^{95}$

An elaboration of these factors produces two hypotheses for why the sex discrimination cases may have been weaker than the race discrimination cases in our data set. ${ }^{96}$ If employers had greater stakes (relative to plaintiffs) in the sex discrimination cases than in the race discrimination cases, the selection effects literature would predict lower success rates for plaintiffs in the sex discrimination cases selected for trial even if judges applied the same standards for evaluating the lack of interest defense in both groups of cases. ${ }^{97}$ Likewise, if employers' attorneys had greater abilities (relative to plaintiffs) to predict the outcomes of sex discrimination

93 According to Priest and Klein, success rates may also deviate from $50 \%$ in cases in which litigation costs are low in relation to settlement costs, or in cases in which expected judgments are high in relation to litigation costs. See id at 39; Theodore Eisenberg, Litigation Models and Trial Outcomes in Civil Rights and Prisoner Cases, 77 Georgetown L J 1567,1579 (1989). A wealth of evidence shows, however, that litigation costs are very high in Title VII class action cases. See Steven A. Holmes, Workers Find It Tough Going Filing Lawsuits Over Job Bias, NY Times AI (Jul 24, 1991); Lewis M. Steel, Why Attorneys Won't Take Civil Rights Cases, The Nation 362 (Mar 26, 1983). Furthermore, expected judgments are relatively low in civil rights cases, including employment discrimination cases. See Eisenberg, 77 Georgetown L J at 1580, 1580 n 62.

- See William F. Baxter, The Political Economy of Antitrust, in Robert D. Tollison, ed, The Political Economy of Antitrust: Principal Papers by William Baxter 16-21 (Lexington, 1980); Priest and Klein, $13 \mathrm{~J}$ Legal Stud 24-26 (cited in note 53).

os See Eisenberg, 77 Georgetown L J at 1582 (cited in note 93).

- Priest and Klein make clear that their model could be applied to cases in which liability turns on the acceptance or rejection of an affirmative defense. See Priest and Klein, $13 \mathrm{~J}$ Legal Stud at $8 \mathrm{n} 26$ (cited in note 53).

97 The same result could occur if plaintiffs had greater stakes, relative to employers, in the race discrimination cases than in the sex discrimination cases. Because it seems more plausible that employers' stakes would vary across race and sex discrimination cases than that plaintiffs' stakes might do so, we characterize this explanation as involving greater relative stakes for employers in sex discrimination cases.

For an analogous explanation of how selection effects might account for differing success rates in various types of civil rights cases, see Eisenberg, 77 Georgetown $L$ J at 1581-82 (cited in note 93 ). 
cases than race discrimination cases, similar results could occur. Under either set of conditions, the courts might have been applying the same standards to evaluate the lack of interest defense in both race and sex discrimination cases. Yet, because a greater proportion of sex discrimination cases that were strong for plaintiffs settled before trial, plaintiffs' success rate would have been lower in sex discrimination cases than in race discrimination cases litigating the lack of interest defense.

Although the selection effects literature generates coherent hypotheses for why the sex discrimination cases in our data set may have been weaker than the race discrimination cases, the validity of the empirical assumptions underlying these hypotheses is not self evident. Why, for example, would employers have greater relative stakes in sex discrimination cases? Although the literature contains no clear delineation of the circumstances that give rise to differential stakes, ${ }^{98}$ a number of commentators have suggested that employers have greater stakes than plaintiffs in employment discrimination cases in general. ${ }^{99}$ According to these commentators, employers may be more likely than plaintiffs to fear reputational harm beyond the expected dollar amount of the judgment. ${ }^{100}$ In addition, Title VII litigation may affect employers' ongoing behavior and prospects for future lawsuits ${ }^{101}$ in a way that it does not

88 The selection effects literature suffers from the absence of a clear, empirically verifiable definition of the circumstances that lead to differential stakes. Professors Schwab and Eisenberg have noted:

[F]ormal model analysts explain many departures from expected patterns of litigation success by invoking the concept of differential stakes. . . Departures from idealized litigation models ... are quickly attributed to differential stakes the parties have in the outcome. If one defines differential stakes broadly enough, they can explain many departures from theoretical predictions. But at some point the explanation becomes a truism .... [T] classes of untidy results and, perhaps more importantly, preempting further probing for explanations.

Stewart Schwab and Theodore Eisenberg, Explaining Constitutional Tort Litigation: The Influence of the Attorney Fees Statute and the Government as Defendant, 73 Cornell L Rev 719, 753 (1988) (footnotes omitted).

${ }_{89}^{\circ}$ See, for example, Eisenberg, 77 Georgetown L J at 1582 (cited in note 93); Siegelman and Donohue, $24 \mathrm{~L} \&$ Soc Rev at 1148 (cited in note 54).

${ }^{100}$ For sources suggesting that harm to reputation may lead to differential stakes, see Eisenberg, 77 Georgetown L J at 1579; Priest and Klein, $13 \mathrm{~J}$ Legal Stud at 40 (cited in note 53).

${ }^{101}$ For sources suggesting that cases involving disruption to ongoing activity and the prospect of future litigation may lead to differential stakes, see Eisenberg, 77 Georgetown L $\mathrm{J}$ at 14; Priest and Klein, $13 \mathrm{~J}$ Legal Stud at 28. For a different explanation of why "repeat players" who are regularly engaged in the activity leading to the dispute will fare better in litigation, see Marc Galanter, Why the "Haves" Come Out Ahead: Speculations on the Limits of Legal Change, $9 \mathrm{~L} \&$ Soc Rev 95 (1974). 
affect plaintiffs. Yet, even if such factors explain why employers have greater stakes than plaintiffs in Title VII cases generally, ${ }^{102}$ it is not clear why such factors would be more salient in sex discrimination cases than in race discrimination cases. To account for why employers' relative stakes would be greater in the sex discrimination cases in our data set requires additional explanation.

One possible explanation for this disparity turns on the greater numbers of women among the potential workers who might take advantage of litigation challenging job segregation. Because in many areas women constitute a larger share of the population and labor force than minorities, employers may believe that the secondary effects of losing classwide sex discrimination cases are more problematic than the effects of losing comparable race discrimination cases. ${ }^{103}$

A second potential explanation turns on the relative levels of government involvement in sex and race discrimination cases. $\mathrm{Be}$ cause government enforcement agencies have limited resources to initiate litigation and are concerned about the precedential effect of their cases on future enforcement efforts, numerous commentators have hypothesized that government plaintiffs have greater

The concern over the disruption of ongoing activity may be particularly acute in classwide cases involving multiple plaintiffs and the potential for wide-ranging prospective remedies. For a detailed description of the types of affirmative remedies the federal courts have ordered historically in Title VII suits, see Eric Schnapper, The Varieties of Numerical Remedies, 39 Stan L Rev 851, 874-912 (1987).

${ }^{102}$ One could argue that neither of these factors adequately explains why employers would have greater stakes than plaintiffs in all types of employment discrimination cases. In cases alleging discrimination in discharge, for example, it is difficult to see why the harm to the employer's reputation would be any greater than the harm to the discharged worker's reputation. Cases alleging discrimination in hiring or other practices associated with job segregation may raise different considerations. In discriminatory hiring cases brought by individuals, the potential disruption to the employer's business or the precedential effect on future lawsuits may increase the employer's stakes beyond the value of the judgment to the plaintiff. Nonetheless, this balance may shift in class action cases or cases initiated by institutional plaintiffs. Where such litigation is part of an effort to restructure the labor market to provide better jobs to minorities or women throughout the community, the plaintiff's stake in obtaining such jobs and in obtaining favorable precedent may be as great or greater than the employer's stake in continuing his current practices.

${ }^{103}$ See Eisenberg, 77 Georgetown L J at 1593 n 95 (cited in note 93) (suggesting that employers' relative stakes in employment discrimination litigation may vary across regions, because "in an area with a small minority population the secondary effects of losing an employment discrimination case may be less troublesome to defendants than in an area with large minority populations"). The same result might have occurred if employers were simply more resistant (or feared that their existing workforces would be more resistant) to hiring women than hiring minorities for the higher-paying jobs at issue in these cases. 
stakes than private plaintiffs in the same types of litigation. ${ }^{104}$ For similar reasons, commentators have suggested that government defendants may have greater stakes than their private counterparts in the same types of litigation. ${ }^{105}$ Thus, if a smaller proportion of sex discrimination cases than race discrimination cases involving the lack of interest argument were initiated by the Justice Department or the EEOC (as opposed to private parties), or if a larger proportion of the sex discrimination cases involved government employers (as opposed to private employers), the different levels of government involvement could help explain why employers may have had greater relative stakes in sex discrimination cases.

This same set of factors may also provide grounding for the differential abilities explanation for sex discrimination plaintiffs' lower success rates. If private attorneys who represent employers in employment discrimination cases had better access to information, greater resources, or more expertise than private attorneys who represent plaintiffs, the employers' bar may have had an advantage over the plaintiffs' bar in predicting case outcomes accurately. ${ }^{108}$ Similarly, some commentators have suggested that government attorneys have an advantage over private attorneys in predicting case outcomes. ${ }^{107}$ If a smaller proportion of sex discrimination cases than race discrimination cases were initiated by the federal government, or if a larger proportion of sex discrimination cases were brought against government employers, these factors

104 See, for example, Richard A. Posner, The Behavior of Administrative Agencies, $1 \mathrm{~J}$ Legal Stud 305, 307-08 (1972); Priest and Klein, $13 \mathrm{~J}$ Legal Stud at 53-54 (cited in note 53); Galanter, 9 L \& Soc Rev at 97-104 (cited in note 101).

${ }^{105}$ See, for example, Schwab and Eisenberg, 73 Cornell L Rev at 752-55 (cited in note 98); Stanton Wheeler, et al, Do the 'Haves' Come Out Ahead: Winning and Losing in State Supreme Courts, 1870-1970, 21 Law \& Soc Rev 403 (1987).

${ }^{106}$ It is plausible, for example, that attorneys who represent employers are more likely than attorneys who represent plaintiffs to work in large firms with extensive resources or in government agencies. In a review of the literature on civil rights cases, Schwab and Eisenberg observed that "most civil rights litigation is not brought by institutional litigators or by large firms engaging in pro bono activity" but instead by the "local, small-firm lawyer." See Schwab and Eisenberg, 73 Cornell L Rev at 768, 769 (cited in note 98). Heinz and Laumann's study of the Chicago bar may be interpreted to provide additional support for this thesis. Of the few lawyers in their sample who devoted at least $25 \%$ of their time to civil rights cases, $29 \%$ worked in small firms (of less than 10 lawyers). See John P. Heinz and Edward O. Laumann, Chicago Lawyers: The Social Structure of the Bar 78-79 $\mathrm{n} 18$ (Russell Sage and American Bar Foundation, 1982). Although another 50\% of the civil rights lawyers in Heinz and Laumann's study worked for government agencies, see id, such lawyers may be more likely to be involved in defending government agencies accused of discrimination than in prosecuting civil rights violations.

${ }^{107}$ See Schwab and Eisenberg, 73 Cornell L Rev at 750-52 (cited in note 98); Wheeler, et al, 21 Law \& Soc Rev at 441 (cited in note 105). 
could help account for why employers' attorneys may have had greater relative abilities to predict the outcomes of sex discrimination cases.

Despite their plausibility, these hypotheses receive only limited support from the data. In our data set, the sex discrimination cases are slightly less likely to involve government plaintiffs, and slightly more likely to involve government employers, than the race discrimination cases. The differences are not large, however. ${ }^{108}$ Furthermore, the cases in our data set may have been affected by the same sort of selection effects under consideration. It is possible, for example, that the government was actually more likely to initiate race discrimination cases than sex discrimination cases challenging job segregation; yet, if employers were more likely to assert the lack of interest defense in sex discrimination cases than in race discrimination cases initiated by the government, our data might show a higher level of government representation among the sex discrimination cases. Thus, the $\mathrm{ABF}$ sample provides a better basis for determining the relative levels of government involvement.

Although the number of cases in the ABF sample is small, the sample provides little evidence that a gap in government representation led employers to have either greater relative stakes or abilities in sex discrimination cases than in race discrimination cases. In fact, in the $A B F$ sample, the sex discrimination cases were slightly less likely than the race discrimination cases to have been brought against government employers. ${ }^{109}$ In addition, the race discrimination cases were only trivially more likely than the sex discrimination cases to involve the federal government as plaintiff. The federal government had only minimal participation in either type of case, initiating only one of the sixty race discrimination cases and none of the seventeen sex discrimination cases. ${ }^{110}$

The ABF sample provides even stronger evidence to undermine the selection effects explanation. According to this explan-

${ }^{108}$ In our data set, $27.8 \%$ of the sex discrimination cases involved the federal government as plaintiff, compared to $34.9 \%$ of the race discrimination cases. In addition, $33.3 \%$ of the sex discrimination cases involved government employers, compared to $20.6 \%$ of the race discrimination cases. See Table 3.

${ }^{109}$ Whereas $17.6 \%$ ( 3 out of 17 ) of the sex discrimination cases involved government employers, $25 \%$ ( 15 out of 60 ) of the race discrimination cases involved such employers.

${ }^{210}$ See also Burstein, $96 \mathrm{Am} \mathrm{J}$ Soc at 1216-17 (cited in note 75) (finding that among published employment discrimination cases decided by the federal courts of appeals between 1965 and 1985, sex discrimination cases were slightly more likely than race discrimination cases to have involved federal government participation on the side of the plaintiffs). 
ation, sex discrimination plaintiffs experienced lower success rates not because the courts treated them less favorably, but because employers' greater relative stakes or abilities led them to settle a greater proportion of filed sex discrimination cases (including a disproportionate number of cases that were strong for plaintiffs). Thus, an important empirical corollary of the selection effects theory is that among the underlying group of filed cases in which the lack of interest argument was a potential defense, the sex discrimination cases should have been more likely to settle and less likely to reach trial than the race discrimination cases. Yet, in the $A B F$ sample, the race and sex discrimination cases were almost equally likely to settle and almost equally likely to reach trial. Whereas 51.7 percent (31 out of 60 ) of the race discrimination cases settled before trial, an almost equivalent 52.9 percent (9 out of 17) of the sex discrimination cases did so. Similarly, 13.3 percent ( 8 out of 60 ) of the race discrimination cases reached trial, and an almost equivalent 11.8 percent (2 out of 17) of the sex discrimination cases reached trial. These findings undercut the proposition that differential selection effects account for the lower success rate in the sex discrimination cases. Indeed, they suggest that a remarkably similar selection process has operated in race and sex discrimination cases.

3. The need to compare the strength of the cases.

Ultimately, both the underlying activity and the selection effects theories explain the difference in success rates by hypothesizing that the sex discrimination cases were weaker than the race discrimination cases in our data set. These explanations are not mutually exclusive with the judicial bias explanation; both weaker evidence and judicial bias could have contributed to the lower success rate in sex discrimination cases. To the extent that sex discrimination plaintiffs presented facts and evidence that were as strong as those presented by race discrimination plaintiffs, however, the lower success rate in sex discrimination cases would suggest that the courts have treated sex discrimination plaintiffs less favorably. Thus, a good way to sort out these explanations is to compare the strength of the two groups of cases.

The next Section provides such a comparison. To evaluate the relative strength of the race and sex discrimination cases, we assume that the courts have treated the evidence and other facts similarly in both types of cases, and then examine whether differences in the composition of the cases render the sex discrimination cases sufficiently weaker for plaintiffs than the race discrimination 
cases to account for the disparity in plaintiffs' success rates. We measure the relative strength of the cases by determining the degree to which they contain the major types of evidence the courts have considered in determining whether to attribute job segregation to employer discrimination or to protected class members' own lack of interest. Since Title VII's enactment, five types of evidence have dominated judicial discussion of the lack of interest argument in both race and sex discrimination cases: (1) evidence that the employer segregated the workforce on the basis of race or sex before the liability period began ("evidence of past discrimination"); (2) evidence that the employer discriminated against individual minorities or women or displayed facially discriminatory behavior toward them during the current liability period ("direct or anecdotal evidence of discrimination"); (3) evidence that the employer made special efforts to attract minorities or women to traditionally segregated jobs ("special efforts"); (4) evidence that the employer engaged in formal recruiting activities, as opposed to relying on informal word-of-mouth recruiting ("formal recruiting"); and (5) evidence that the employer relied on a subjective system to evaluate and select candidates for the jobs at issue ("subjective selection system"). Controlling for these five types of evidence provides an objective, comprehensive measure of the strength of the merits of the cases. In addition to these evidentiary factors, we analyze other factors which extend beyond the merits of the cases but which nonetheless may have influenced case outcomes, such as whether the government was a party and whether blue-collar or white-collar work was at issue. We also control for the time period (1967-77 or 1978-89), doctrinal framework (disparate treatment or disparate impact), and level of court (district court or court of appeals) involved.

Although we rely exclusively on the courts' opinions to gather the data for our analyses, ${ }^{111}$ our methodology is designed to minimize the risk of incorporating into the data any biases in judges' attitudes and approaches toward the evidence. To determine whether a particular type of evidence was presented, we adopted a uniform definition of that type of evidence, and then searched the

11 Most other scholars who have performed content analyses of published employment discrimination cases have also relied exclusively on the courts' opinions to gather the data for their analyses. See, for example, Paul Burstein, Attacking Sex Discrimination in the Labor Market: A Study in Law and Politics, 67 Soc Forces 641 (1989); Paul Burstein and Kathleen Monaghan, Equal Employment Opportunity and the Mobilization of Law, $20 \mathrm{~L} \&$ Soc Rev 355 (1986); Eisenberg, 77 Georgetown L J at 1567 (cited in note 93); Mills, 124 Pac Soc Rev 196 (cited in note 77). 
opinions to discover whether the court made a statement acknowledging the existence of that type of evidence. For example, to determine whether evidence of special efforts was present, we searched the entire opinion for any statement acknowledging that the employer had taken affirmative steps to attract minorities or women to the jobs at issue. We did not rely on whether the court characterized those steps as "special efforts" or considered them sufficiently impressive to support an inference that protected class members lacked interest in the work, because such characterizations might reflect the very biases in judges' evaluations of the evidence that our analyses are designed to investigate. In cases in which the court's opinion made no reference to a particular type of evidence, we assumed that that type of evidence was not presented.

Our methodology controls indirectly for whether the evidence met a minimal threshold of quality or persuasiveness, for unless the evidence was minimally credible, the court may not have been willing to acknowledge its existence in the opinion. Thus, to the extent that sex discrimination plaintiffs were less likely than race discrimination plaintiffs to present evidence of a sufficient quality to warrant an affirmative acknowledgment in the opinion, our analyses control for such differences in quality. Of course, differences in the quality of the evidence are not the only reason why judges may have mentioned some types of evidence less frequently in sex discrimination cases: biased attitudes may have led to the same phenomenon. If, for example, judges considered a particular type of evidence less probative of the lack of interest issue in sex discrimination cases than in race discrimination cases, judges might have referred to that type of evidence less frequently in sex discrimination decisions. To the extent that such differences in judicial reporting occurred, our analyses would underreport the presence of that type of evidence in sex discrimination cases. As a result, our analyses would be biased in favor of the weaker evidence explanation (and against the judicial bias explanation). ${ }^{112}$

\footnotetext{
${ }^{112}$ A simple mathematical example illustrates this point. In our data set, $77.8 \%$ (49 out of 63) of the race discrimination cases included evidence of past discrimination, but only $64.8 \%$ (35 out of 54) of the sex discrimination cases did so. See Table 3. Suppose, however, that the courts regarded evidence of past discrimination as a powerful refutation of the lack of interest argument in race discrimination cases, but much less powerful in sex discrimination cases. Suppose further that because of these attitudes, judges acknowledged the existence of evidence of past discrimination in all the race discrimination cases in which plaintiffs presented it, but they failed to acknowledge this same evidence in seven of the sex discrimination cases in which plaintiffs presented it. If the seven additional sex discrimina-
} 
Beyond this screening factor, our analyses do not control directly for the quality or persuasiveness of individual pieces of evidence. Because judges' descriptions of the evidence may be colored by their own views about the effect or weight that type of evidence should be given in particular classes of cases, it would have been impossible to measure the quality of the evidence without building into our analyses the very biases in judges' attitudes and approaches toward particular types of evidence that our analyses are designed to investigate.

\section{B. A Comparison of the Content of Race and Sex Discrimination} Cases

Our analyses of the content of the race and sex discrimination cases suggests little difference in their evidentiary and factual composition. Table 3 presents the means (or the percentage of cases in which each factor was present) for the evidence and non-evidence variables in sex and race discrimination cases, respectively. The second column shows what percentage of the race discrimination cases included the five types of evidence and other case characteristics. The third column presents analogous information for the sex discrimination cases.

tion cases were included, $77.8 \%$ (42 out of 54 ) of the sex discrimination cases would have included evidence of past discrimination, rather than $64.8 \%$. Thus, our data set would underreport the presence of evidence of past discrimination in the sex discrimination cases. In fact, our data set would make it appear that the sex discrimination cases were weaker than the race discrimination cases with respect to evidence of past discrimination, when in reality the two sets of cases were equally likely to include this type of evidence. As a result, our assessment of the relative strength of the race and sex discrimination cases would overstate the weaker evidence explanation (and understate the judicial bias explanation) for sex discrimination plaintiffs' lower success rate. 
Table 3: Variable Means for Race and Sex Discrimination Cases

\begin{tabular}{lcc}
\hline Variables & $\begin{array}{c}\text { Race } \\
(\mathrm{n}=63)\end{array}$ & $\begin{array}{c}\text { Sex } \\
(\mathrm{n}=54)\end{array}$ \\
\hline Direct or Anecdotal Evidence & $60.3 \%$ & $59.3 \%$ \\
Special Efforts & $34.9 \%$ & $38.9 \%$ \\
Subjective Selection System & $66.7 \%$ & $68.5 \%$ \\
Formal Recruiting & $14.3 \%$ & $22.2 \%$ \\
Evidence of Past Discrimination & $77.8 \%$ & $64.8 \%$ \\
Government Plaintiff & $34.9 \%$ & $27.8 \%$ \\
Government Defendant & $20.6 \%$ & $33.3 \%$ \\
Blue-Collar Work & $84.1 \%$ & $72.2 \%$ \\
Disparate Impact Analysis & $68.3 \%$ & $27.8 \%$ \\
\hline
\end{tabular}

These figures reveal few differences in the evidentiary content of the race and sex discrimination cases. In fact, the two groups of cases include almost equivalent proportions of three of the five types of evidence. As the first row shows, the race and sex discrimination cases were almost equally likely to contain direct or anecdotal evidence of discrimination. Direct evidence refers to proof of overt discrimination, such as explicit bars on hiring women or minorities, sexually or racially segregated advertising, or statements directly revealing discriminatory intent. Anecdotal evidence refers to evidence that the employer discriminatorily rejected individual women or minority applicants or discouraged them from applying; it provides concrete instances of discrimination against individuals who expressed an interest in the work. Because both forms of discrimination may deter interested class members from applying, direct and anecdotal evidence might be expected to help plaintiffs overcome the lack of interest argument. On the other hand, failing to present such evidence might not have hurt plaintiffs. If the courts were disinclined to attribute job segregation to minorities' or women's own lack of interest in higher-paying employment, judges may have been willing to hold employers liable even in the absence of concrete proof that employers discriminated against already-interested individuals. ${ }^{113}$

11 See Schultz, 103 Harv L Rev at 1774 (cited in note 20) (demonstrating that between 1967 and 1971, the lower courts did not require plaintiffs to present anecdotal evidence of discrimination in order to counter employers' arguments that minorities lacked interest in 
The sex and race discrimination cases also included similar proportions of evidence of special efforts. By claiming that their special efforts to attract women or minorities to traditionally segregated jobs failed, employers hope to buttress their arguments that these groups lacked interest in such jobs. ${ }^{114}$ In addition, the sex and race discrimination cases were almost equally likely to include evidence that the employer relied on a subjective selection system. In an objective system, the employer selects candidates on the basis of criteria that are measured and weighted uniformly across candidates. By contrast, in a subjective system, the employer relies on unmeasurable criteria on which evaluators might rate the same candidates differently, or uses measurable criteria but has no standardized system to ensure that evaluators give these criteria the same weight across candidates. If, for example, an employer delegated to supervisors discretion to select "the most qualified" candidates for promotion, without specifying particular criteria to be used by the supervisors to evaluate the qualifications of all candidates on a uniform basis, the employer would be relying on a subjective selection system. Traditionally, the lower courts have condemned such systems, because they provide the opportunity for conscious or unconscious bias to influence evaluators' judgments. ${ }^{115}$ Thus, by supplementing their statistical proof with evidence that

predominately white jobs). For examples of race discrimination cases in which courts concluded that anecdotal evidence was not required, see Jones v Lee Way Motor Freight, Inc., 431 F2d 245, 247 (10th Cir 1970) ("True, no specific instances of discrimination have been shown. However, because of the historically all white make-up of the Company's [job] category, it may well be that negroes simply did not bother to apply."); United States $v$ Sheet Metal Workers Int'l Ass'n, Local Union No. 36, 416 F2d 123, 127 (8th Cir 1969).

11 See Schultz, 103 Harv L Rev at 1789-92 (cited in note 20) (discussing employers' use of this strategy in sex discrimination cases). For illustrations of race discrimination cases in which employers have sought to use this strategy, see Sheet Metal Workers, 416 F2d at 13839 (employer argued that even after extensive efforts to attract Blacks to the union's apprenticeship program, "[n]ot one has taken the initiative to apply"); League of United Latin American Citizens $v$ City of Santa Anna, 410 F Supp 873, 881 (C D Cal 1976); Stamps v Detroit Edison Co., 365 F Supp 87, 109 (E D Mich 1973), rev'd on other grounds, 515 F2d 301 (6th Cir 1975).

118 One of the classic condemnations of subjective selection systems was expressed by the Fourth Circuit in 1972:

Elusive, purely subjective standards must give way to objectivity if statistical indicia of discrimination are to be refuted .... [I]n the absence of objective criteria applied to all workers alike, the statistics indicate that race is the only identifiable factor explaining the disparity between the jobs held by white employees and those held by black employees .... [T] [Te lack of objective guidelines for hiring and promotion . . . are badges of discrimination that serve to corroborate, not to rebut, the racial bias pictured by the statistical pattern of the company's work force.

Brown v Gaston County Dyeing Machine Co., 457 F2d 1377, 1382 (4th Cir 1972). See also Rowe v General Motors, 457 F2d 348, 359 (5th Cir 1972). 
the employer used a subjective selection system, plaintiffs seek to strengthen the inference of discrimination and to undercut the lack of interest explanation.

Only the two remaining evidence variables suggest dimensions on which the sex discrimination cases may have been somewhat weaker than the race discrimination cases. Sex discrimination cases were somewhat more likely to involve evidence of a formal recruiting system. In the absence of formal recruiting systems, employers tend to rely on their employees to spread information about jobs and job openings to friends and relatives. Because white workers tend to communicate job information mostly to other whites, the lower courts have concluded that informal, word-of-mouth recruiting systems are racially discriminatory. ${ }^{116}$ In light of this reasoning, employers who do not engage in formal recruiting should have a more difficult time persuading judges that protected class members' failure to apply was due to lack of interest rather than a lack of knowledge about job opportunities. The difference between the sex and race discrimination cases on this variable is not large, however.

A more sizeable difference in the evidentiary composition of the sex and race discrimination cases exists in connection with evidence of past discrimination. This evidence should help plaintiffs counter the lack of interest defense. In an influential body of early race discrimination cases, the courts held that where an employer has discriminated in the past, minorities' failure to pursue traditionally segregated jobs does not signal a lack of interest in the work, but rather a sense of futility created by the employer's history of discrimination. ${ }^{117}$ To the extent that this same reasoning

\footnotetext{
${ }^{116}$ See, for example, EEOC $v$ Detroit Edison Co., 515 F2d 301, 313 (6th Cir 1975) ("The practice of relying on referrals by a predominantly white work force rather than seeking new employees in the marketplace for jobs was found to be discriminatory ... [T] he findings are supported by substantial evidence."); United States v Georgia Power Co., 474 F2d 906, 925 (5th Cir 1973) ("Under word-of-mouth hiring practices, friends of current employees admittedly received the first word about job openings. Since most current employees are white, word-of-mouth hiring alone would tend to isolate blacks from the 'web of information' which flows around opportunities at the company."); Parham v Southwestern Bell Tel. Co., 433 F2d 421, 427 (8th Cir 1970) (same).

${ }^{117}$ See Schultz, 103 Harv L Rev at 1772-73 (cited in note 20) (discussing the early cases which developed the futility doctrine). For the first case we found which applied the futility doctrine, see Cypress u Newport News General \& Nonsectarian Hosp. Ass'n, 375 F2d 648, 653 (4th Cir 1967) ("That so few Negro physicians have applied is not indication of a lack of interest, but indicates, we think, a sense of the futility of such an effort in the face of the notoriously discriminatory policy ... "). See also Wade v Mississippi Cooperative Extension Service, 372 F Supp 126, 141 (N D Miss 1974) ("That so few blacks have applied for promotions does not demonstrate a lack of interest but rather indicates that, given the his-
} 
applies to sex discrimination cases, the fact that sex discrimination plaintiffs were less likely to introduce evidence of past discrimination would have weakened their chances of prevailing on the lack of interest defense.

The next three variables in Table 3 reflect information about the identity and status of the parties: whether the federal government was a plaintiff; whether the defendant was a federal, state, or local government; and whether the jobs to which plaintiffs sought access involved blue-collar or white-collar work. From a legal standpoint, these factors do not affect the merits and should not have influenced the outcome of the lack of interest argument: Judges are not supposed to treat government litigants differently from private litigants or white-collar plaintiffs differently from blue-collar plaintiffs. Nonetheless, the literature suggests that these factors may have influenced case outcomes.

A number of researchers have estimated that government litigants-plaintiffs and defendants-have higher success rates than their private counterparts in the same type of litigation. ${ }^{118}$ Assuming that this phenomenon is valid for Title VII cases involving the lack of interest argument, the lower level of government plaintiffs or the higher level of government defendants in the sex discrimination cases might have contributed to sex discrimination plaintiffs' lower success rates. In any event, the overall difference in presence of government litigants between sex and race discrimination cases is not large.

Although the vast majority of both race and sex discrimination cases raising the lack of interest defense involved blue-collar work, the sex discrimination cases were somewhat less likely to involve such work. The literature contains contradictory predictions about whether employment discrimination plaintiffs seeking blue-collar or white-collar work will have higher success rates. Because allowing disadvantaged groups access to lower-level jobs is less

tory of discriminatory practices, blacks concluded that it was futile, if not ill-advised, to apply for higher professional jobs when vacancies occurred.").

${ }^{118}$ Commentators have proposed a number of reasons why government litigants may have higher success rates. The government's finite resources may lead it to initiate only cases in which it has a higher-than-usual likelihood of winning; the government's interest in future precedent may increase its stake in the litigation; the government's repeat-player status may yield organizational advantages; or the government may simply invest greater resources to strengthen the cases it chooses to initiate. See notes 104-05. In addition, as my colleague Bill Whitford pointed out to me, judges may give greater credence to suits initiated by the government because the decision to file suit has been made by an official who has a less obvious interest in its outcome than a private litigant. 
threatening to the power structure, ${ }^{119}$ some commentators have suggested that plaintiffs should have greater chances of success in cases involving blue-collar work. ${ }^{120}$ Others predict that white-collar plaintiffs will have a better chance of prevailing, because they bring greater resources to the litigation. ${ }^{121}$ Neither of these predictions are specific to cases raising the lack of interest defense, however, and each assumes that the type of work sought will cut in the same direction in both sex and race discrimination cases. Thus, there is no consensus about whether the underrepresentation of blue-collar cases serves to strengthen or weaken the sex discrimination cases in our data set.

The biggest difference between the sex and race discrimination cases arises in connection with the doctrinal analysis variable. This variable does not attempt to measure the strength of the merits of a case; it reveals whether the court used a disparate impact framework or instead relied exclusively on a disparate treatment framework to analyze the plaintiffs' claim. ${ }^{122}$ Under a disparate treatment analysis, plaintiffs must prove that the employer acted with a discriminatory intent; ${ }^{123}$ a disparate impact analysis requires no such showing. ${ }^{124}$ Numerous commentators have suggested that the difficulty of proving intentional discrimination makes a disparate treatment framework less favorable to plaintiffs than a disparate impact framework. ${ }^{125}$ This observation may be

119 See, for example, James R. Kluegel, The Causes and Costs of Racial Exclusion from $J o b$ Authority, 43 Am Soc Rev 285, 286-87 (1978); Wendy C. Wolf and Neil D. Fligstein, Sex and Authority in the Workplace, 44 Am Soc Rev 235, 240 (1979).

${ }^{120}$ See, for example, Elizabeth Bartholet, Application of Title VII to Jobs in High Places, 95 Harv L Rev 947 (1982).

${ }^{121}$ See, for example, Burstein, 67 Soc Forces at 649 (cited in note 111); Mills, 24 Pac Soc Rev at 207 (cited in note 77 ).

${ }^{122}$ In some cases, the court analyzed the claim under both a disparate treatment and a disparate impact framework. We treated these cases as disparate impact cases, to reflect the fact that plaintiffs got the benefit of the allegedly more favorable disparate impact analysis.

${ }^{123}$ See, for example, Texas Dept of Community Affairs v Burdine, 450 US 248, 252-56 (1981) (individual disparate treatment cases require proof of discriminatory intent); Teamsters, 431 US at 324, 335 n 15 (1977) (classwide disparate treatment cases require proof of discriminatory intent).

${ }^{124}$ To establish a prima facie showing of disparate impact, the plaintiff need only prove that apparently neutral selection criteria operated to exclude protected class members at a disproportionate rate. See, for example, Dothard $v$ Rawlinson, 433 US 321, 330 (1977); Griggs v Duke Power Co., 401 US 424, 429-30 (1971). The employer bears the burden of proving the business necessity of the challenged criteria. See the Civil Rights Act of 1991, §§ 104(m), 105(k)(1)(a)(ii), Pub L No 102-66,-105 Stat 1071 (1991).

${ }^{125}$ See, for example, Kenneth L. Karst, The Costs of Motive-Centered Inquiry, 15 San Diego L Rev 1163 (1978). For a recent summary of the literature discussing the burdensomeness of an intent standard, see Eisenberg and Johnson, 76 Cornell L Rev at 1160-61 (cited in note 76 ). 
particularly applicable to cases involving the lack of interest defense, because the suggestion that protected class members lacked interest in the work may undercut the inference of discriminatory intent required to prove disparate treatment more directly than it undermines a showing of disparate impact. ${ }^{126}$ In our data set, the sex discrimination cases were substantially less likely than the race discrimination cases to be analyzed under a disparate impact framework. This disparity is largely attributable to the effect of time. Most of our sex discrimination cases were decided after $1977,{ }^{127}$ and the use of the disparate impact model declined dramatically after that year. ${ }^{28}$ The less frequent use of the disparate

126 In classwide disparate treatment cases, the plaintiffs make a prima facie case of intentional discrimination by proving that protected class members are significantly underrepresented in the employer's workforce or in particular jobs. If the employer shows that this disparity is attributable to the class members' own lack of interest in the work, this showing directly undercuts the inference of intentional discrimination that would otherwise be drawn from plaintiff's statistical proof. See, for example, Hazelwood School District $v$ United States, 433 US 299, 311 \& n 17 (1977) (suggesting that minorities' failure to apply would undercut the inference of intentional discrimination by providing an alternative explanation for their underrepresentation in the employer's workforce). In disparate impact cases, by contrast, the role of the lack of interest argument is more subtle. The plaintiff makes a prima facie case of disparate impact by demonstrating that the employer's use of one or more selection criteria operated to exclude protected class members at a disproportionate rate. In some cases, however, the employer argues that because the only class members who would tend to be interested in the work are those who meet the required criteria, the criteria could not have operated to exclude eligible women or minorities at a disproportionate rate. See, for example, Dothard, 433 US at 348 (White dissenting) (stating that plaintiff' evidence failed to establish that the employer's use of a height and weight requirement had excluded a disproportionate number of women from prison guard positions, on the ground that he was not "convinced that a large percentage of the actual women applicants, or those who are seriously interested in applying, for [such] positions would fail to satisfy the height and weight requirements"). This use of the lack of interest argument is controversial, however, because it embroils the court in circular logic that potentially undermines the entire disparate impact model. Id at 330 (recognizing that protected class members' failure to apply would not necessarily undermine a showing of disparate impact, because protected class members may have been deterred from applying by the very requirements the plaintiffs claim have a disparate impact).

127 In our data set, $79.6 \%$ (43 out of 54) of the cases decided from 1967-1977 were analyzed under a disparate impact framework, but only $23.8 \%$ (15 out of 63 ) of the cases decided from 1978-1989 were analyzed under a disparate impact framework. The volume of disparate impact cases declined in both the race and sex discrimination cases in our data set. Yet, because the early sex discrimination cases were less likely than the early race discrimination cases to involve a disparate impact analysis, this decline was less dramatic for the sex discrimination cases. Among race discrimination cases, the proportion of disparate impact cases declined from $88.4 \%$ (38 out of 43 ) in the 1967-77 period to $25 \%$ (5 out of 20) in the 1978-89 period. Among sex discrimination cases, the proportion of disparate impact cases declined from $45.5 \%$ ( 5 out of 11 ) in the early period to $23.3 \%$ (10 out of 43 ) in the later period.

128 For speculations as to why the number of cases in which the courts used a disparate impact framework may have declined, see text at notes 190-94. 
impact model in sex discrimination cases, although not weakening the merits of such cases relative to the race discrimination cases, may nevertheless have decreased sex discrimination plaintiffs' chances of prevailing.

Overall, however, the race and sex discrimination cases are comparable in content-particularly on the evidentiary dimensions, which measure the relative strengths of the cases. The few differences that emerge from Table 3 do not seem sufficient to explain the sizeable gap in plaintiffs' success rates in sex and race discrimination cases. That sex discrimination plaintiffs won less often even though their cases had comparable characteristics suggests that judges may have responded to the same evidence and facts differently in sex and race discrimination cases. If judges viewed sex segregation as a less serious problem than race segregation, they may have been more predisposed to accept the lack of interest explanation in such cases. As a result, they may have imposed different-and more difficult-standards for refuting this argument in sex discrimination cases. The next Section examines this possibility in more detail.

C. A Comparison of Judicial Standards for Evaluating the Lack of Interest Defense

Schultz's previous article provides a framework for understanding why judges may have reacted differently to the same evidence in race and sex discrimination cases. Most fundamentally, Schultz found that the courts' responses to the evidence have been framed by differing assumptions about the sources of minorities' and women's work aspirations. In early race discrimination cases, the courts acknowledged that minorities' job preferences had been formed and artificially limited by discriminatory labor market conditions. Yet, in sex discrimination cases, the courts have assumed that women's work preferences are shaped through early socialization (or even innate predisposition), rather than in response to labor market discrimination. As a result, judges have tended to view women's job preferences as impervious to employers' influence. Schultz found that these differences in assumptions have led the courts to evaluate the same types of evidence less favorably in sex discrimination cases.

The analyses in this Section confirm that the courts have responded to the same types of evidence differently-and less favorably-in sex discrimination cases than in race discrimination cases. Our results reveal that in the 1965-89 period as a whole, each of the five types of evidence has had a markedly different effect on 
the outcome of the lack of interest argument in sex and race discrimination cases. Table 4 presents the results of logistic regression analyses which test the influence of each type of evidence and other case characteristics on the plaintiffs' likelihood of prevailing on the lack of interest argument, while controlling simultaneously for all the other factors. ${ }^{129}$ The first set of analyses (the "full models") includes all nine content variables analyzed in Table 3 , as well as a date variable, which reflects whether the case was decided in the 1967-77 period or the 1978-89 period. The second set of analyses (the "parsimonious models") excludes variables of little or no significance. ${ }^{130} \mathrm{~A}$ positive coefficient for a variable indicates that other factors being equal, the presence of that factor increased plaintiffs' likelihood of winning. A negative coefficient means that, all else equal, the presence of that factor decreased plaintiffs' likelihood of winning. In addition to reporting the coefficients, we report the t-ratios for each variable. ${ }^{131}$

${ }^{129}$ Because our analyses treat outcome as a dichotomous variable (either the plaintiff wins or loses on the lack of interest argument), logistic regression models are more appropriate than ordinary least squares regression models. In logistic regression, the dependent variable or "logit" [L] is the natural log of the odds ratio of the probability that an event $P$ occurs to the probability that it does not occur [Ln (P/1-P)]. While the log odds ratio is a linear function of the independent variables, the probability itself is not linear. That is, the effect of a change in one of the independent variables on the probability of an event occurring also depends on the initial values of the other variables in the model. For an introduction to logit models, see Eric A. Hanushek and John E. Jackson, Statistical Methods for Social Scientists 179-216 (Academic Press, 1977); David W. Hosmer, Jr. and Stanley Lemeshow, Applied Logistic Regression (Wiley, 1989). For another study that uses logit models to analyze the influence of various types of evidence and other factors on the outcomes of civil rights cases, see Eisenberg and Johnson, 76 Cornell L Rev at 1185 (cited in note 76).

${ }^{230}$ The parsimonious models exclude variables of little or no significance. The chisquared statistic for the full race model is 39.23 and for the parsimonious race model is 36.28 , which yields a difference of 2.95 . The critical value of the chi-squared statistic at the $10 \%$ level of confidence for four degrees of freedom is 7.78 . Thus, excluding the direct/ anecdotal evidence, special efforts, government plaintiff, and disparate impact variables from the race model does not significantly decrease the fit of the model. Similarly, the chisquared statistic for the full sex model is 19.81 and for the parsimonious model is 11.12, which produces a difference of 8.69 . The critical value of the chi-squared statistic at the $10 \%$ level of confidence for seven degrees of freedom is 12.0. Consequently, the six variables excluded from the full sex model are not jointly significant. For an analogous use of parsimonious models, see Eisenberg and Johnson, 76 Cornell L Rev at 1188-89 (cited in note 76).

131 Because our search strategy was designed to locate every published decision that addressed the lack of interest defense, the collection of claims in our study approximates a universe rather than a sample. Strictly speaking, it is unnecessary to test for statistical significance of the relationship between variables in a universe, as opposed to a sample of cases. Here and elsewhere, however, we report the results from tests of statistical significance to give the reader a sense of the relative importance of the variables in influencing outcomes. In the logits, a t-ratio of 1.64 or greater indicates that the coefficient is significant at .10 or less. A .10 level of significance means that the probability that the outcomes would 
TABle 4: Logistic Regression Results for Race and Sex Discrimination Cases Analyzed Separately: The Influence of the Evidence and Other Facts on Plaintiffs' Likelihood of Prevailing

\begin{tabular}{|c|c|c|c|c|}
\hline & \multicolumn{2}{|c|}{ Full Models } & \multicolumn{2}{|c|}{ Parsimonious Models } \\
\hline & Race & Sex & Race & Sex \\
\hline $\begin{array}{l}\text { Independent } \\
\text { Variables } \\
\end{array}$ & $\begin{array}{c}\text { Coefficient } \\
\text { (t-ratio) }\end{array}$ & $\begin{array}{c}\begin{array}{c}\text { Coefficient } \\
\text { (t-ratio) }\end{array} \\
\end{array}$ & $\begin{array}{c}\text { Coefficient } \\
\text { (t-ratio) }\end{array}$ & $\begin{array}{r}\text { Coefficient } \\
\text { (t-ratio) } \\
\end{array}$ \\
\hline Constant & $\begin{array}{c}-5.268 \\
(-2.111)\end{array}$ & $\begin{array}{c}0.213 \\
(0.144)\end{array}$ & $\begin{array}{c}-3,489 \\
(-1.948)\end{array}$ & $\begin{array}{c}0.011 \\
(0.011)\end{array}$ \\
\hline $\begin{array}{l}\text { Evidence of Past } \\
\text { Discrimination }\end{array}$ & $\begin{array}{c}2.405 \\
(1.968)\end{array}$ & $\begin{array}{l}-1.167 \\
(-1.576)\end{array}$ & $\begin{array}{c}1.832 \\
(1.828)\end{array}$ & $\begin{array}{l}-1.096 \\
(-1.626)\end{array}$ \\
\hline $\begin{array}{l}\text { Direct/Anecdotal } \\
\text { Evidence }\end{array}$ & $\begin{array}{r}-0.161 \\
(-0.149)\end{array}$ & $\begin{array}{c}2.163 \\
(2.332)\end{array}$ & - & $\begin{array}{l}1.227 \\
(1.956)\end{array}$ \\
\hline Special Efforts & $\begin{array}{c}1.653 \\
(1.425)\end{array}$ & $\begin{array}{l}-1.246 \\
(-1.621)\end{array}$ & - & - \\
\hline Formal Recruiting & $\begin{array}{c}-4.355 \\
(-2.381)\end{array}$ & $\begin{array}{c}1.307 \\
(1.428)\end{array}$ & $\begin{array}{l}-3.787 \\
(-2.288)\end{array}$ & - \\
\hline $\begin{array}{l}\text { Subjective Selection } \\
\text { System }\end{array}$ & $\begin{array}{l}2.850 \\
(2.587)\end{array}$ & $\begin{array}{c}-0.760 \\
(-0.833)\end{array}$ & $\begin{array}{c}2.607 \\
(2.622)\end{array}$ & - \\
\hline Blue Collar Work & $\begin{array}{c}3.155 \\
(1.920)\end{array}$ & $\begin{array}{c}-1.195 \\
(-1.297)\end{array}$ & $\begin{array}{c}3.044 \\
(2.106)\end{array}$ & - \\
\hline $\begin{array}{l}\text { Government } \\
\text { Plaintiff }\end{array}$ & $\begin{array}{c}-0.766 \\
(-0.685)\end{array}$ & $\begin{array}{c}-0.846 \\
(-1.055)\end{array}$ & - & $\overline{-}$ \\
\hline $\begin{array}{l}\text { Government } \\
\text { Defendant }\end{array}$ & $\begin{array}{c}4.371 \\
(2.135)\end{array}$ & $\begin{array}{c}-1.180 \\
(-1.487)\end{array}$ & $\begin{array}{c}3.927 \\
(2.155)\end{array}$ & - \\
\hline $\begin{array}{l}\text { Disparate Impact } \\
\text { Analysis }\end{array}$ & $\begin{array}{c}1.081 \\
(0.892)\end{array}$ & $\begin{array}{c}2.160 \\
(2.118)\end{array}$ & 一 & $\begin{array}{l}1.287 \\
(1.701)\end{array}$ \\
\hline Date $(\geq 1978)$ & $\begin{array}{c}-1.879 \\
(-1.548)\end{array}$ & $\begin{array}{l}1.654 \\
(1.594)\end{array}$ & $\begin{array}{l}-2.522 \\
(2.660)\end{array}$ & - \\
\hline Log Likelihood & -18.076 & -26.930 & -19.551 & -31.275 \\
\hline $\begin{array}{l}\text { Likelihood Ratio Test* } \\
\text { (vs. model with } \\
\text { constant term only) }\end{array}$ & $\begin{array}{l}\mathrm{x}^{2}{ }_{(10)}= \\
39.23\end{array}$ & $\begin{array}{l}\mathrm{x}^{2}{ }_{(10))}= \\
19.81\end{array}$ & $\begin{array}{l}x^{2}{ }^{(6)}= \\
36.28\end{array}$ & $\begin{array}{l}x^{2}= \\
11.12\end{array}$ \\
\hline Number of Cases & 63 & 54 & 63 & 54 \\
\hline
\end{tabular}

* The log-likelihood ratio is defined as two times the absolute value of the difference between the log-likelihood for the model with the constant term only and the competing model. This ratio is distributed $x^{2}$ (d), where d.f. (degrees of freedom) is the number of variables added to the model. The log-likelihood for the model with a constant term only is -36.835 for the sex discrimination cases and -37.691 for the race discrimination cases. 
1. The evidence.

The results for the five evidence variables show that the courts have evaluated the same types of evidence differently in race and sex discrimination cases. Remarkably, the coefficient for every evidence variable had different signs across the race and sex models. In fact, each variable had a significantly different effect on plaintiffs' likelihood of winning in race and sex discrimination cases. ${ }^{132}$

Evidence of past discrimination significantly increased plaintiffs' chances of prevailing in race discrimination cases; the coefficients for this variable are large and significant in both race models. In sex discrimination cases, however, evidence of past discrimination did not increase plaintiffs' likelihood of winning (and in fact tended to decrease it). This discrepancy is consistent with the results of Schultz's earlier study. As documented more fully there, the courts have held very different assumptions about the role of historical discrimination in shaping minorities' and women's work aspirations. ${ }^{133}$ In race discrimination cases, the courts acknowledged the history of racial discrimination in the labor market and recognized that minorities' current work interests had been formed and limited in that context. Judges applied the futility doctrine, which held that if minorities had failed to apply for traditionally segregated jobs, this did not signal any lack of interest in the work but rather a sense of futility created by the employer's history of discrimination. ${ }^{134}$ Furthermore, the courts were willing to infer the requisite history of discrimination from evidence of statistical underrepresentation alone. Judges understood that many systems of job segregation had been implemented through informal customs so deeply ingrained that they did not require formally stating. Accordingly, the courts did not require plaintiffs to produce "smoking gun" proof that the employer had once operated an overt system of segregation. ${ }^{135}$

have varied as much as they did across cases where the factor in question was present or absent, by chance alone, is one in ten.

${ }^{132}$ We estimated a model that pools the race and sex discrimination cases, and includes interaction terms between a race/sex dummy variable and each of the variables specified in the full models. The coefficients for those interaction terms measure the difference in the effects of the variables on the outcomes of race and sex discrimination cases. The results from this model confirm that each coefficient in the full race model is different from the corresponding coefficient in the full sex model at a .10 or less level of significance, with the exception of the government plaintiff and disparate impact coefficients.

${ }^{233}$ See Schultz, 103 Harv L Rev at 1771-73, 1781-89 (cited in note 20).

134 See note 117.

${ }^{235}$ For examples of cases in which courts concluded that the employer had engaged in historical discrimination from evidence of statistical underrepresentation alone, see Jones $v$ 
In sex discrimination cases, by contrast, evidence of past discrimination has not helped plaintiffs overcome the lack of interest argument, because the courts have failed to recognize that past discrimination has shaped and restricted women's current work aspirations. In fact, many conservative judges who have accepted the lack of interest argument actually deny that employers ever discriminated against women. Even when confronted with statistical evidence of long-standing, extreme patterns of sex segregation, conservative judges have refused to attribute these patterns to historic discrimination and have attributed them instead to women's own past choices. ${ }^{138}$ According to these judges, such patterns merely confirm that women have always found higher-paying, nontraditional work unappealing. ${ }^{137}$ In this conservative approach, women have always had a timeless set of "feminine" attributes, including an aversion for such work.

While conservative judges have denied the history of sex discrimination in the labor market, even those more liberal judges who have rejected the lack of interest argument have not relied heavily on evidence of past discrimination to counter this argument. ${ }^{138}$ Although these judges acknowledge the history of discrimination against women, they appear skeptical that past generations of women would have taken nontraditional jobs even if employers had permitted them to do so. ${ }^{139}$ Rather, the liberal rationale for rejecting the lack of interest argument rests on a vision of progress, in which women's current aspirations for nontraditional work represent a sharp break from those of most women in the past. This

Tri-County Electric Cooperative, Inc., 512 F2d 1, 2 (5th Cir 1975); Jones v Lee Way Motor Freight, Inc., 431 F2d 245, 247-48 (10th Cir 1970); Parham v Southwestern Bell Tel. Co., 433 F2d 421, 426-27 (8th Cir 1970).

${ }^{138}$ For a more complete discussion of this trend, see Schultz, 103 Harv L Rev at 178385 (cited in note 20 ).

${ }_{137}$ See, for example, EEOC v Mead Foods, Inc., 466 F Supp 1, 3 (W D Okla 1977) ("[C]ommon practical knowledge tells us that certain work in a bakery operation is not attractive to females. This is a fact of life that an Act of Congress cannot overcome.") (emphasis added). See also EEOC $v$ Korn Industries, 17 FEP (BNA) 954, 959 (D SC 1978) ("There has been no showing that any female has ever wanted to work for the Hardwood Division. ... Although the plaintiff may call this stereotype female classification, the Court has not seen females clamoring to work in such jobs . ...").

${ }^{138}$ Although courts rejected the lack of interest argument in the overwhelming majority of cases in which they acknowledged the employer's past discrimination, only a few of these courts drew on the employer's history to explain women's present failure to apply. See, for example, Chrapliwy o Uniroyal, Inc., 458 F Supp 252, 262 (N D Ind 1977). In most of these cases, judges seemed to mention the employer's past discrimination only in passing.

${ }^{139}$ See, for example, Catlett $v$ Missouri Highway \& Transportation Comm'n, 828 F2d 1260 (8th Cir 1987); Capaci v Katz \& Besthoff, Inc., 711 F2d 647 (5th Cir 1983). For a discussion of these cases, see Schultz, 103 Harv L Rev at 1785-87 (cited in note 20). 
approach attributes the historical change in women's work aspirations not to increased labor market opportunity, but to other unspecified "societal" influences. Ultimately, this liberal approach converges with the more conservative one, for neither acknowledges the influence of historical labor market discrimination in shaping women's contemporary work status.

The courts' different perspectives on the history and sources of race and sex segregation may also have led to divergent treatment of other types of evidence in race and sex discrimination cases. In race discrimination cases, for example, direct or anecdotal evidence of discrimination made little or no difference to the outcome of the lack of interest argument. Yet, in sex discrimination cases, it significantly increased plaintiffs' chance of prevailing. This pattern is also consistent with the results of Schultz's earlier study. ${ }^{140}$ In race discrimination cases, the courts refused to individualize the problem of discrimination. When employers tried to discredit the statistical proof by pointing to plaintiffs' failure to produce direct or anecdotal evidence of discrimination, the courts held that plaintiffs need not present individual instances of discrimination to refute employers' arguments that minorities lacked interest in nontraditional work. ${ }^{141}$ Courts simply presumed that if minorities had always had the same work opportunities as whites, they would not have chosen lower-paying, less desirable jobs. In sex discrimination cases, by contrast, judges have insisted on direct or anecdotal evidence of discrimination. While conservative judges have stated explicitly that they will disregard statistical proof of segregation without supplemental evidence that the employer discriminated against interested individuals, ${ }^{142}$ even more liberal judges have looked to such evidence to confirm that contemporary women desire nontraditional jobs. ${ }^{143}$ Absent proof that the employer took

110 See Schultz, 103 Harv L Rev at 1774, 1793-99 (cited in note 20).

141 See note 113 and accompanying text.

142 See, for example, EEOC v Sears, Roebuck \& Co., 628 F Supp 1264, 1324-25 (N D Ill 1986) (rebuking the plaintiff for failing to introduce "even one witness who could credibly testify that Sears discriminated against her" and concluding that the failure to produce such individual testimony proved that the patterns of sex segregation revealed by the statistical evidence reflected women's lack of interest rather than employer discrimination); Piva $v$ Xerox Corp., 654 F2d 591, 595 (9th Cir 1981); Gilbert v East Bay Municipal Dist., 19 FEP (BNA) 304,307 (N D Cal 1979).

143 See, for example, EEOC v Sears, Roebuck \& Co., 839 F2d 302, 362 (7th Cir 1988) (Cudahy concurring in part and dissenting in part) (emphasizing that the EEOC's proof of sex discrimination would have been stronger if it had produced "even a handful of witnesses to testify that Sears had frustrated their childhood dreams of becoming commission sellers") (emphasis added); Kohne v Imco Container Co., 480 F Supp 1015, 1027-28 (W D Va 1979) (citing the testimony of women employees to conclude that women "are or have been 
concrete actions to prevent individual women from realizing their already-formed aspirations for such work, the courts have been reluctant to attribute sex segregation to employer discrimination. ${ }^{144}$

A similar bias accounts for the courts' differential evaluation of evidence of special efforts. In sex discrimination cases, employers' claims of special efforts to attract women to nontraditional work decreased plaintiffs' chances of winning. In race discrimination cases, however, such evidence did not hurt plaintiffs, but tended to help them. This pattern, too, is the same as the one that emerged in Schultz's previous work. ${ }^{145}$ In the early era at least, the courts imposed on employers with historically segregated workforces an affirmative duty to attract minority workers to formerly segregated jobs. Judges evaluated employers' alleged efforts to attract minorities skeptically, with an eye toward results. ${ }^{148} \mathrm{Be}-$ cause they believed that minorities' reluctance to seek traditionally segregated jobs had been conditioned by employers' discriminatory practices, judges presumed that this reluctance could be overcome by employers' persistent efforts. ${ }^{147}$ In sex discrimination cases, however, the courts' assumption that women's work aspirations are forged through influences outside the labor market has led judges to be more skeptical about the extent to which employers can interest women in nontraditional work. Judges have tended to accept uncritically employers' assertions that their special efforts to at-

interested in the spectrum of traditionally male jobs at the plant"); Ostapowicz $v$ Johnson Bronze Co., 369 F Supp 522, 537-38 (W D Pa 1973) (relying on the fact that a number of women had failed to opt out of the class to reject the lack of interest argument).

144 For a more complete discussion of the courts' reliance on anecdotal evidence in sex discrimination cases, see Schultz, 103 Harv L Rev at 1793-99 (cited in note 20).

148 See id at 1773-74, 1789-93.

148 Employers frequently tried to exonerate themselves by claiming that they had made special efforts to recruit minorities into predominantly white jobs. Courts held that such efforts, however laudable, did not absolve employers from liability. See, for example, Parham v Southwestern Bell Tel. Co., 433 F2d 421, 429 (8th Cir 1970); United States v Central Motor Lines, Inc., 338 F Supp 532, 549-50, 565-66 (W D NC 1971).

-147 In case after case, courts condemned employers' efforts for "fall[ing] short of what is necessary." United States $v$ Sheet Metal Workers' Int'l Ass'n, Local Union No. 36, 416 F2d 123, 139 (8th Cir 1969). See also Jones v Lee Way Motor Freight, Inc., 431 F2d 245, 248 (10th Cir 1970); United States v Hayes Int'l Corp., 415 F2d 1038, 1044 (5th Cir 1969). This approach was based on a belief that employers' efforts could ultimately make a difference. This belief emerges powerfully from the Fifth Circuit's decision in Morrow $v$ Crisler, 491 F2d 1053 (5th Cir 1974) (en banc). The court held that the relief granted by the district court was inadequate to eliminate the effects of the Mississippi Highway Patrol's longstanding history of racial discrimination. When the Patrol tried to justify its record by arguing that it had hired every qualified African American who had applied to be a patrol officer, the court stated: "If this be true, it is apparent that either the qualifications are discriminatory in effect, or the State has not conducted a sufficient recruitment campaign to enlist blacks who meet those requirements." Id at 1055-56. 
tract women failed, ${ }^{148}$ despite the fact that most employers' efforts fell far short of what is encompassed even in a traditional affirmative action plan. ${ }^{148}$

Evidence of formal recruiting also had different effects in race and sex discrimination cases. In race discrimination cases, judges' recognition that informal, word-of-mouth recruiting systems tend to exclude minorities from the network of job information led them to penalize employers who had not implemented formal recruiting systems. Employers who failed to implement such systems were significantly less likely to convince judges that minorities' underrepresentation was due to lack of interest, as the negative coefficients for this variable in the race models show. ${ }^{150}$ The courts have not displayed the same concern about the exclusionary effects of informal, word-of-mouth recruiting on women, however. ${ }^{151}$ Many judges have failed to recognize that even though social networks may be sexually integrated, male workers are far less likely to share information about job opportunities with women than with other men. ${ }^{152}$ Judges have also overlooked the fact that

${ }^{148}$ See, for example, Ste. Marie v Eastern R.R. Ass'n, 650 F2d 395, 403 (2d Cir 1981); Sears, 628 F Supp at 1292-94, 1306, 1324; Davis v City of Dallas, 483 F Supp 54, 61 (N D Tex 1979).

148 See Schultz, 103 Harv L Rev at $1790 \mathrm{n} 154$ (cited in note 20) (stating that of the 21 claims of special efforts in sex discrimination cases, only seven involved written affirmative action plans that appeared to include goals and timetables for women). Of course, not even a written affirmative action plan guarantees that an employer is serious about trying to integrate women into nontraditional work. In Parker v Siemens-Allis, Inc., the company's official affirmative action plan included the following statement about why it was not discriminatory to assign women to electrical work:

There are some things that appeal to the females such as: clean working conditions, routine work, which once learned, gives the female the opportunity to plan the family budget, menu and other responsibilities directly related to family ties.

601 F Supp 1377, 1385 (E D Ark 1985).

${ }^{130}$ For examples of cases in which the courts rejected the lack of interest argument in part because the employer had relied on an informal, word-of-mouth recruiting system, see Stamps, 365 F Supp at 117 ("In light of [the company's] practice of friends-and-relatives recruiting, its failure to advertise job opportunities generally, and its reputation of excluding blacks, [it] cannot claim a lack of black applicants as a defense for its failure to hire them."). See also Parham, 433 F2d at 426-27; Sheet Metal Workers, 416 F2d at 139; Central Motor Lines, 338 F Supp at 558, 561-62.

${ }^{181}$ For examples of cases in which the courts concluded that informal, word-of-mouth recruiting does not tend to exclude women from the network of information about maledominated jobs, see Wilkins $v$ University of Houston, 654 F2d 388, 400 (5th Cir 1981) ("[T]he obstacle of widespread segregation faced by potential black employees is not present for women ... [W] decline to assume that word-of-mouth recruiting . . . operates to isolate women from the web of information surrounding job opportunities ..."); EEOC $v$ Service Container Corp., 19 FEP (BNA) 1614 (W D Okla 1976).

${ }^{182}$ An extensive literature documents that male workers are more likely to share job information with other men than with women. For this reason, men are more likely to se- 
an employer's reliance on informal, "old-boy" networks to recruit new candidates may communicate to women a message of unwelcomeness that discourages them from applying. ${ }^{153}$ As a result, in sex discrimination cases the courts have been no more likely to reject the lack of interest argument from employers who relied on word-of-mouth recruiting than from employers who used more formal, open recruiting methods.

The courts have also evaluated employers' use of subjective selection systems differently in sex and race discrimination cases. In race discrimination cases, evidence that the employer relied on a subjective selection system substantially increased plaintiffs' chances of winning; the coefficient for this variable is large, positive and significant. Many judges were suspicious of employers who failed to develop clear, objective hiring criteria, yet attributed that dearth of minority applicants to minorities' own lack of interest in the jobs. ${ }^{164}$ The small and insignificant coefficient for this variable in the full sex model suggests, however, that courts have failed to exhibit the same suspicion in sex discrimination cases. In light of the fact that subjective selection systems provide as much opportunity for sexual bias as for racial bias, ${ }^{150}$ the courts' failure to attach importance to the nature of the selection process in sex discrimination cases suggests that judges were simply less inclined to perceive sex segregation as the product of potentially discriminatory processes. ${ }^{156}$

cure their jobs through personal contacts, while women are more likely to rely on formal job-search methods. For a summary of this literature, see Patricia A. Roos and Barbara F. Reskin, Institutional Factors Contributing to Sex Segregation in the Workplace, in Reskin, ed, Sex Segregation in the Workplace at 235, 241-42, 245-46 (cited in note 2).

${ }^{163}$ For a more complete discussion of this point, see Schultz, 103 Harv L Rev at 181214 (cited in note 20).

154 See, for example, United States $v$ N.L. Industries, Inc., 479 F2d 354, 368-69 (8th Cir 1973); Wade $v$ Mississippi Cooperative Extension Service, 372 F Supp 126, 141 (N D Miss 1974); Stamps v Detroit Edison Co., 365 F Supp 87, 111-13 (E D Mich 1973), rev'd on other grounds, 515 F2d 301 (6th Cir 1975).

${ }^{165}$ See, for example, Gerald R. Salancik and Jeffrey Pfeffer, Uncertainty, Secrecy and the Choice of Similar Others, 41 Soc Psych 246 (1978); Philip E. Tetlock, Accountability: The Neglected Social Context of Judgment and Choice, in L.L. Cummings and Barry M. Staw, eds, Research in Organizational Behavior 297 (JAI Press, 1985).

${ }_{186}$ See, for example, EEOC $v$ Sears, Roebuck \& Co., 839 F2d 302, 331-32 (7th Cir 1988) (distinguishing precedent that condemned the use of subjective selection processes, and affirming the district court's refusal to infer that such subjective processes facilitated sex discrimination); Durant v Owens-Illinois Glass Co., 656 F2d 89 (5th Cir 1981) (same). 


\section{The characteristics of the parties.}

The results for the variables that pertain to the parties' status also suggest that the courts have relied on different assumptions when assessing the lack of interest argument in sex and race discrimination cases. In race discrimination cases, plaintiffs who sought access to blue-collar work were significantly more likely to win on the lack of interest argument than plaintiffs who sought access to white-collar work; the coefficients for this variable are large and significant in the race models. In sex discrimination cases, however, the opposite was true. Plaintiffs were slightly more likely to win in cases involving white-collar work than in cases involving blue-collar work (though not significantly so). These results suggest that the courts have acted on common stereotypes about the types of work that are appropriate for women and minorities. Schultz's earlier study showed that judges have tended to accept popular images of blue-collar work as "heavy," "dirty," and "masculine," while envisioning white-collar work as "light," "clean," and "feminine."157 Thus, in sex discrimination cases, the courts may have been less willing to accept employers' arguments that women lack interest in white-collar work, because they associated such work with femininity. ${ }^{158}$ Conversely, in race discrimination cases, judges may have been less willing to believe that minorities lack interest in blue-collar jobs, because popular stereotypes depict blue-collar and manual labor as suitable for minorities (particularly minority males). ${ }^{159}$ These attitudes parallel larger changes in the economy. Since Title VII's enactment, women have made greater strides in integrating white-collar employment, while minority men have made greater strides in integrating blue-collar employment. ${ }^{160}$

${ }^{167}$ See Schultz, 103 Harv L Rev at 1801-02 (cited in note 20).

${ }^{18 B}$ In her study of federal district court cases alleging sex discrimination in employment, Mills offered a similar explanation for her finding that female plaintiffs had higher success rates in cases involving white-collar work than in cases involving blue-collar work. As she observed, a class bias was long evident in federal affirmative action programs, in which the government did not begin enforcing affirmative action guidelines to integrate women into blue-collar occupations until the late 1970s. See Mills, 24 Pac Soc Rev at 207 (cited in note 77).

${ }^{180}$ See, for example, Christine G. Cooper, Title VII in the Academy: Barriers to Equality for Faculty Women, 16 U C Davis L Rev 975, 982-83 (1983) (arguing that judges readily understand Title VII cases in which Black men seek access to blue-collar jobs).

${ }^{160}$ Compare James J. Heckman and J. Hoult Verkerke, Racial Disparity and Employment Discrimination Law: An Economic Perspective, 8 Yale L \& Policy Rev 276, 284 (1990) (summarizing research which shows that since 1965, "the largest movements of black workers into new and higher paying occupations came in unskilled and low skill blue collar job 
The government defendant variable also had opposite effects in sex and race discrimination cases. In race discrimination cases, plaintiffs fared far better in cases against government employers than in cases against private employers; the coefficient is large, positive, and significant. Yet, in sex discrimination cases, the pattern reverses: plaintiffs are more likely to win cases against private employers. Although we have no straightforward explanation for these results, it seems plausible that courts have imposed on government employers a greater responsibility to redress racial segregation in employment than sexual segregation. A bias in this direction would be consistent with constitutional standards, which require government agencies to satisfy more stringent standards to justify racial disparities than sexual disparities in general. ${ }^{161}$

Among all the variables pertaining to the parties, only the government plaintiff variable had similar effects in sex and race discrimination cases. In both groups of cases, government plaintiffs were slightly less likely than private plaintiffs to prevail on the lack of interest argument, after controlling for the evidence and other case characteristics. Given that government enforcement attorneys are believed to enjoy advantages over private attorneys, this pattern and its explanation may be unique to cases addressing the lack of interest defense. To many judges, the fact that local women and minorities were willing to initiate their own private class actions may have signalled a higher level of interest in the jobs than if the lawsuit had been brought by remote federal government attorneys. In fact, some judges relied on plaintiffs' involvement in the class to reject employers' arguments that women were not interested in nontraditional jobs. ${ }^{162}$ Other judges chastised EEOC attorneys in stern terms that border on accusations of

classifications such as manufacturing operatives") (emphasis in original), with Beller, Trends in Occupational Segregation at 19 (cited in note 2) (documenting that women's gains were "most pronounced among the white-collar occupations, especially professional and managerial, [but] little or no change occurred among the blue-collar occupations"); and Reskin and Roos, Job Queues, Gender Queues at 16-20 (cited in note 83) (reporting similar findings).

${ }_{182}$ In Fourteenth Amendment Equal Protection Clause cases, courts evaluate government actions that treat the races differently under a standard of strict scrutiny. See, for example, Palmore $v$ Sidoti, 466 US 429, 432-33 (1984); Loving $v$ Virginia, 388 US 1,11 (1967). By contrast, courts evaluate government actions that treat the sexes differently under a less stringent standard that has become known as intermediate or "heightened" scrutiny. See, for example, Mississippi Univ. for Women v Hogan, 458 US 718, 721 (1982); Rostker v Goldberg, 453 US 57, $69-70$ (1981); Craig v Boren, 429 US 190, 204 (1976).

${ }^{182}$ See Ostapowicz, $369 \mathrm{~F}$ Supp at 537-38 (relying on the fact that a number of women had not opted out of the class to support the proposition that women did have interest in the work at issue). 
"stirring up trouble" by bringing sex discrimination suits where local women had little desire for nontraditional work. ${ }^{183}$

\section{Doctrinal framework.}

Our regressions confirm that plaintiffs fare better in disparate impact cases than in disparate treatment cases. Other factors being equal, the courts' use of a disparate impact analysis increased plaintiffs' chances of winning in both sex and race discrimination cases. This effect was more pronounced in sex discrimination cases, however. Although we have no clear explanation for this discrepancy, one interpretation is consistent with the results for the other variables. If a disparate impact analysis helped sex discrimination plaintiffs more than race discrimination plaintiffs, the converse is also true: a disparate treatment analysis harmed sex discrimination plaintiffs more than race discrimination plaintiffs. This means that in disparate treatment cases, the courts were less willing to attribute sex segregation to intentional discrimination by the employer. Thus, the results for this variable may reflect the same sort of bias that affected judges' responses to the evidence and other facts.

\section{Court level.}

We also examined the effect of court level on the outcomes of the cases. The first panel of Table 5 (Panel A) shows plaintiffs' success rates in district court cases that were not appealed (column 2 ), in district court cases that were appealed (column 3), and in the resulting group of appellate cases (column 4). The second panel (Panel B) shows what percentage of appellate court decisions reversed district court judgments for plaintiffs (column 2), for employers (column 3), and for both parties combined (column 4).

\footnotetext{
${ }^{\text {ses }}$ See, for example, EEOC v. Sears, Roebuck \& Co., 628 F Supp 1264, 1324-25 (N D Ill 1986) (berating the EEOC attorneys for "turn[ing] a blind eye to reality" in assuming that women sales applicants were as interested as men in higher-paying commission sales jobs, and for failing "to produce even one witness who could credibly testify that Sears discriminated against her"); EEOC v Mead Foods, Inc., 466 F Supp 1, 4 (W D Okla 1977) (berating the EEOC attorneys for "refus[ing] to accept the facts of life about work in a bakery" and remarking that had they done so, "their statistics would have been answered on a basis other than sex").
} 
TABLE 5: Plaintiffs' Success Rates in District Court and Court of Appeals Cases, and Reversal Rates in Court of Appeals, By Race and Sex

\begin{tabular}{|c|c|c|c|c|c|c|}
\hline \multirow[b]{3}{*}{ Race } & \multicolumn{4}{|c|}{ A. Plaintiffs' Success Rates } & \\
\hline & \multicolumn{2}{|c|}{$\begin{array}{c}\text { District Court } \\
\text { Cases } \\
\text { (Not Appealed) }\end{array}$} & \multicolumn{2}{|c|}{$\begin{array}{c}\text { District Court } \\
\text { Cases } \\
\text { (Appealed) }\end{array}$} & \multicolumn{2}{|c|}{$\begin{array}{c}\text { Court of } \\
\text { Appeals } \\
\text { Cases }\end{array}$} \\
\hline & $74.2 \%$ & $(23 / 31)$ & $25.0 \%$ & $(8 / 32)$ & $68.8 \%$ & $(22 / 32)$ \\
\hline Sex & $57.1 \%$ & $(20 / 35)$ & $26.3 \%$ & $(5 / 19)$ & $57.9 \%$ & $(11 / 19)$ \\
\hline
\end{tabular}

B. Reversal Rates in Courts of Appeals, by Party Who Won in District Court

\begin{tabular}{lcccccc}
\hline & \multicolumn{2}{c}{ P Won Below } & \multicolumn{2}{c}{ D Won Below } & \multicolumn{2}{c}{ Total } \\
Race & $50.0 \%$ & $(4 / 8)$ & $75.0 \%$ & $(18 / 24)$ & $68.8 \%$ & $(22 / 32)$ \\
Sex & $40.0 \%$ & $(2 / 5)$ & $57.1 \%$ & $(8 / 14)$ & $52.6 \%$ & $(10 / 19)$ \\
\hline
\end{tabular}

Sex discrimination plaintiffs had lower success rates than race discrimination plaintiffs in both non-appealed district court decisions and court of appeals decisions. Race discrimination plaintiffs won 74.2 percent of the district court cases and 68.8 percent of the court of appeals cases; sex discrimination plaintiffs won 57.1 percent of the district court cases and 57.9 percent of the court of appeals cases. In appealed district court cases, however, both race and sex discrimination plaintiffs had experienced much less success; race discrimination plaintiffs won only 25 percent, and sex discrimination plaintiffs won only 26.3 percent of such cases. Thus, the appellate courts were helpful to both groups of plaintiffs.

Although the courts of appeals helped race and sex discrimination plaintiffs, they helped race discrimination plaintiffs more. ${ }^{164}$ Unlike other studies that have found that courts of appeals tend to affirm trial court decisions, ${ }^{165}$ Table 5 reveals that in cases address-

\footnotetext{
104 When we added a variable to test for the infuence of the court of appeals to our full sex model, the coefficient for the court of appeals variable turned out to be small, positive and insignificant (Beta $=0.434$ and $t$-ratio $=0.518$ ). In an analogous model for the race cases, the court of appeals coefficient was much larger, though still insignificant (Beta = 1.307 and t-ratio $=0.854$ ). In both of these models, adding the court of appeals variable did not substantially alter the results for the other variables.

$16 s$ See, for example, Theodore Eisenberg and Stewart J. Schwab, What Shapes Perceptions of the Federal Court System?, 56 U Chi L Rev 501, 517-18 (1989); Wheeler, et al, 21 Law \& Soc Rev at 406-07 (cited in note 105).
} 
ing the lack of interest argument the courts of appeals have tended to reverse lower court decisions. The appellate courts reversed rulings against race discrimination plaintiffs at disproportionately_and remarkably - high rates. Whereas the courts of appeals reversed 57.1 percent of all district court rulings against plaintiffs in sex discrimination cases, they reversed a phenomenal 75 percent of district court rulings against plaintiffs in race discrimination cases. In race discrimination cases, the courts of appeals were three times more likely to reverse rulings against plaintiffs than rulings against employers; in sex discrimination cases, they were only two times more likely to do so.

These results are consistent with the courts' overall differences in approach to race and sex discrimination cases. At least in the early days of Title VII enforcement, the courts of appeals displayed extraordinary zeal to ensure that trial judges did not frustrate Title VII by attributing racial segregation to minorities' own lack of interest in higher-paying jobs. That appellate judges displayed less fervor for reversing rulings against plaintiffs in sex discrimination cases suggests that they were less likely to perceive sex segregation as a serious form of discrimination that demanded dismantling.

\section{Summary and implications.}

Our analyses strongly suggest that the courts have imported gender bias into their resolution of the lack of interest argument. Neither the underlying activity nor the selection effects explanation adequately explains why sex discrimination plaintiffs have prevailed less frequently than race discrimination plaintiffs. The underlying activity explanation is based on the dubious empirical premise that sex discrimination in employment has been less pervasive than race discrimination since 1965 . The selection effects explanation hypothesizes that because different factors governed the selection of filed race and sex discrimination cases for litigation, a greater proportion of the sex discrimination cases (including a greater proportion of sex discrimination cases that were strong for plaintiffs) settled before trial. The ABF data suggest, however, that the selection processes for Title VII race and sex discrimination cases in which the lack of interest argument provides a potential defense have been very similar. In the $A B F$ sample, the race and sex discrimination cases were almost equally likely to settle and to reach trial.

Contrary to the underlying activity and selection effects hypotheses, moreover, our analyses suggest that the sex discrimina- 
tion cases were not weaker for plaintiffs to a degree sufficient to account for sex discrimination plaintiffs' lower success rates. As noted earlier, our analyses do not control for the persuasive quality of the evidence within each category beyond a certain minimal threshold. Although one might argue that the persuasive quality of the evidence offered by sex discrimination plaintiffs was sufficiently weaker than that offered by race discrimination plaintiffs to explain the disparity, this argument is implausible. Our logits revealed that the courts have given all five types of evidence the opposite effects in race and sex discrimination cases. To attribute these results to differences in the quality of the evidence, one must assume that for each of the five types of evidence analyzed, the persuasiveness of the proof presented by sex discrimination plaintiffs was so much weaker than that presented by race discrimination plaintiffs that unbiased judges would have reacted by giving that type of evidence a contrary effect on the outcome. Thus, for example, sex discrimination plaintiffs' evidence of past discrimination would have to have been so unpersuasive that unbiased judges regarded it as actually harming plaintiffs' cases-even though the identical evidence aided race discrimination plaintiffs. Even if one were willing to accept such heroic assumptions about the evidence, this would still not explain why the courts responded to three of the four non-evidentiary factors differently in race and sex discrimination cases. The judicial bias explanation explains the courts' responses better.

Taken as a whole, the courts' different responses to the evidence create a more stringent legal standard for sex discrimination plaintiffs to refute the lack of interest argument. Historically, race discrimination plaintiffs have been able to overcome the lack of interest argument by presenting evidence of historical segregation, the lack of formal recruiting, and the use of a subjective selection system. In sex discrimination cases, however, these types of evidence have not helped plaintiffs. To overcome the lack of interest argument, sex discrimination plaintiffs have been forced to present direct or anecdotal evidence of discrimination-the equivalent of "smoking gun" proof that the employer discriminated against already-interested women. In addition, judges have tended to accept uncritically employers' allegations that their special efforts to attract women to higher-paying jobs failed. These differences in the courts' approaches to the evidence, as well as their responses to the non-evidentiary factors, suggest that the courts have failed to treat sex segregation in employment with the same seriousness as race segregation. 
The differences in the courts' standards for evaluating the lack of interest argument in sex and race discrimination cases remain even after controlling for the effect of time on each group of cases. Yet, as the coefficients for the date variable in Table 4 confirm, time has not had the same effect in sex and race discrimination cases. After controlling for the evidence and other case characteristics, sex discrimination plaintiffs were somewhat more likely to win on the lack of interest argument in the 1978-89 period than in the 1967-77 period. Race discrimination plaintiffs, however, were substantially less likely to win on this argument in the more recent period. These results suggest that while courts may have "softened" their approach toward sex discrimination plaintiffs, they have "hardened" their approach toward race discrimination plaintiffs. The next Section examines the reasons for race discrimination plaintiffs' declining success.

III. The Change in Perceptions of Racial Segregation on the Job: Judicial Responses to the Lack of interest Defense in Race Discrimination Cases in the Early and Modern Eras

A. Alternative Theoretical Explanations for the Decline in Success Rates

The familiar judicial bias and weaker evidence theories provide potential explanations for the decline in race discrimination plaintiff's' success rates. Just as biased attitudes led judges to treat sex discrimination plaintiffs less favorably than race discrimination plaintiffs in the aggregate group of cases, so too, a shift in judicial attitudes may have led judges to treat race discrimination plaintiffs less favorably in more recently decided cases. If, after an initial period of vigorous Title VII enforcement, federal judges began to believe that racial employment discrimination was no longer a serious problem, alternative explanations for remaining patterns of racial segregation may have become more appealing. The lack of interest defense would have provided an alternative interpretation of segregation that resonated with popular attitudes about the sources of minorities' economic disadvantage. Alternatively, plaintiffs' success rates may have declined because their cases became weaker over time. The courts may have continued to apply the same pro-plaintiff standards in the modern period, but judges ruled against plaintiffs more frequently because their cases provided a weaker refutation of the lack of interest argument.

The underlying activity theory provides one explanation for why the race discrimination cases may have been weaker in the 
modern period than in the earlier era. According to this explanation, racial discrimination was prevalent and blatant during the early era of Title VII enforcement. Over time, however, as employers have changed their practices, racial discrimination has become less pervasive and, as a result, race discrimination cases have become weaker and more difficult to win. As one scholar expressed it, "[S]econd generation cases are different. [Their] facts ... arose in the 1970s, after employers and unions had implemented changes. The discrimination pattern is no longer so clear. . . . Plaintiffs' cases are therefore less substantial, and less winnable under any standard." 166 Thus, in the modern era, "employers may [have] prevail[ed] in a greater number of cases because the extent of discrimination has been reduced."167

Although this is a popular explanation for declining success in the courts, it contains an important leap of logic. Even if racial discrimination declined substantially over time, this would not necessarily imply that race discrimination plaintiffs filed weaker cases in the more recent period. As noted in our earlier discussion of the underlying activity theory, a number of complex processes intervene between the experience of discrimination and the decision to litigate. There is evidence, for example, that victims of employment discrimination have found it increasingly difficult to secure legal representation since the late 1970 s. ${ }^{168}$ It has also become more difficult for lawyers to bring class action lawsuits since then. ${ }^{169}$ As a result of these new pressures, in the modern period, minorities may have been able to obtain lawyers and to initiate class actions only in circumstances involving evidence and facts that were at least as strong as those presented in the earlier cases.

Furthermore, the types of racial discrimination associated with job segregation may not have declined since the late 1970s to a degree that accounts for the sizeable decrease in plaintiffs' success rates. Although there has been progress in eliminating racial

${ }^{166}$ Blumrosen, 6 Indus Rel L J at 347 (cited in note 37).

167 Id.

168 See, for example, Holmes, NY Times at A1 (cited in note 93); Janet Sanders, Title VII: The Boom is Over, Natl L J I (May 28, 1979); Steel, The Nation at 362 (cited in note 93); Ray Terry, Eliminating the Plaintiff's Attorney in Equal Employment Litigation: $A$ Shakespearean Tragedy, 5 Labor Law 63 (1989).

${ }^{188}$ For evidence that class action employment discrimination suits have declined dramatically between 1975 and 1989, see Donohue and Siegelman, 43 Stan L Rev at 1019-21 (cited in note 59). For a description of the changes in judicial doctrine that have made it more difficult for plaintiffs to initiate Title VII class actions, see Judith Johnson, Rebuilding the Barriers: The Trend in Employment Discrimination Class Actions, 19 Colum Hum Rts L Rev 1 (1987). 
segregation over the past twenty-five years, the biggest advances occurred in the late 1960s and early 1970s. ${ }^{170}$ Recent evidence suggests that this progress stagnated in the late 1970 s. $^{171}$ Since then, African Americans have made little advancement into higher-paying occupations, particularly upper-level white-collar employment. ${ }^{172}$ Although employers may have eliminated many of the most overt forms of discrimination, evidence shows that they continue to discriminate. ${ }^{173}$ A 1991 study by the Urban Institute found, for example, that Chicago and Washington, D.C. employers favored white job seekers over equally qualified African Americans approximately twenty percent of the time. ${ }^{174}$ Braddock and McPartland's 1983 national survey found that most employers continue to use informal recruiting practices that draw on racially segregated social networks. African Americans who rely on such segregated networks are more likely to end up in low-paying, segregated jobs than those who have access to more integrated networks. ${ }^{175}$ In addition, the survey disclosed that many employers evaluate individual minority candidates on the basis of negative group stereotypes. As a result, African Americans tend to be excluded from jobs believed to require academic skills in reading and math, quick learning, and good judgment. ${ }^{176}$

A controversy exists about the extent to which legal regulation prompted the early progress toward eliminating job segregation that occurred in Title VII's wake. ${ }^{177}$ To those who believe that the law contributed significantly to desegregation, the direction of cau-

${ }^{170}$ See Heckman and Verkerke, 8 Yale L \& Policy Rev at 282.83 (cited in note 160) (summarizing the relevant research and concluding that the "rate of black progress accelerated between 1965 and 1975, [and] then levelled off').

${ }^{171}$ See Farley and Allen, The Color line at 274, 277-80 (cited in note 2); Bound and Freeman, Black Economic Progress at 41, 45-46 (cited in note 2); Malveaux and Wallace, Minority Women in the Workplace at 273-85 (cited in note 2).

${ }^{272}$ See, for example, Farley and Allen, The Color Line at 271-74 (cited in note 2); Bound and Freeman, Black Economic Progress at 45-46 (cited in note 2); Donohue and Siegelman, 43 Stan L Rev at 1010 (cited in note 59). See also Jonathan S. Leonard, The Impact of Affirmative Action Regulation and Equal Employment Law on Black Employment, $4 \mathrm{~J}$ Econ Persp 47, 58 (Fall 1990) (reporting that in the 1970s, affirmative action regulations led federal contractors to provide greater job opportunities for minorities than non-regulated contractors; in the 1980 s, however, this pattern reversed itself).

173 See, for example, Kirschenman and Neckerman, The Meaning of Race for Employers at 203-04 (cited in note 24); Braddock and McPartland, $43 \mathrm{~J}$ Soc Issues at 5, 6-24 (cited in note 38 ).

174 See Turner, Fix, and Struyk, Opportunities Denied at 61 (cited in note 38).

${ }_{175}$ See Braddock and McPartland, $43 \mathrm{~J}$ Soc Issues at 7-9, 11 (cited in note 38).

${ }^{178}$ See id at 14-17.

${ }^{177}$ For two recent overviews of this controversy, see John J. Donohue IIII and James J. Heckman, Continuous Versus Episodic Change: The Impact of Civil Rights Policy on the 
sation in the underlying activity explanation may be reversed. The substantial decline in plaintiffs' success rates in race discrimination cases may not reflect a decrease in the level of employment discrimination against minorities since the late $1970 \mathrm{~s}^{178}$ Instead, race discrimination plaintiff's' lower success rates may reflect a shift toward a less favorable legal climate, which has itself contributed to the lack of progress toward dismantling job segregation since that time. ${ }^{179}$ Ironically, the early advances toward greater racial equality may have contributed to this development. If the visible signs of increased opportunities for minorities led judges to believe that racial discrimination had largely been eliminated, they may have become more inclined to interpret remaining patterns of job segregation as the expression of minorities' own lack of interest in higher-paying jobs.

Before inferring that judicial attitudes and standards have become less favorable to race discrimination plaintiffs, however, one must also consider the possibility that the decline in their success rates is attributable to a change in the types of cases selected for litigation. As our earlier discussion of selection effects indicated, the lower success rates in race discrimination cases may signal a change in the parties' relative stakes or sophistication rather than a change in the legal standards. If employers' stakes or ability to predict case outcomes increased substantially relative to plaintiffs' between the 1967-77 and 1978-89 periods, this could help explain why race discrimination plaintiffs were less successful in the modern period. According to the selection effects literature, an increase in employers' relative stakes or abilities would have led them to offer more to settle race discrimination cases, especially cases that were particularly strong for plaintiffs. The resultant pool of claims

Economic Status of Blacks, 29 J Econ Literature 1603 (1991); and Heckman and Verkerke, 8 Yale L \& Policy Rev at 286-91 (cited in note 160).

${ }^{178}$ Donohue and Siegelman's recent analysis of the number of charges of hiring discrimination filed with the EEOC between 1966 and 1986 may provide some support for the proposition that racial discrimination in hiring has not declined dramatically since the late 1970s. According to their chart, the number of hiring discrimination charges fell between 1977 and 1979, but rose fairly steadily thereafter. By 1986, the number of charges had risen to a level approaching the peak 1976 level. See Donohue and Siegelman, 43 Stan L Rev at 1016, Figure 6 (cited in note 59). Their analysis is not limited to charges of racial discrimination in hiring, however, but includes charges of discrimination in hiring on all legally protected grounds (including sex, national origin, religion, and age). It is possible that the aggregate trends they report do not hold true for charges of racial discrimination in hiring alone.

179 See, for example, Bound and Freeman, Black Economic Progress at 46-47 (cited in note 2); Farley and Allen, The Color Line at 281 (cited in note 2); Leonard, $4 \mathrm{~J}$ Econ Persp at 58 (cited in note 172). 
that were litigated in the more recent period would have been weaker and less winnable than the earlier cases even under the same legal standards. As a result, plaintiffs would have experienced lower success rates in the more recent period. ${ }^{180}$

This explanation raises an important issue. Why would employers' relative stakes in race discrimination cases challenging job segregation have increased so substantially since the late 1970s? It is difficult to see, for example, why employers would have become more concerned about the damage to their reputations in the 197889 period than they were in the 1967-77 period. It seems equally plausible that any stigma associated with an accusation of discrimination would have waned over time, as increasing numbers of employers were held liable for employment discrimination. Although an increased judicial willingness to order employers to restructure their practices might have raised employers' relative stakes over time, this explanation also seems implausible. In light of the serious legal and political challenges to affirmative action that began in the late 1970s, it seems likely that the courts have ordered such relief less frequently, not more frequently, in the 1978-89 period.

There is one plausible set of explanations for why employers' relative stakes might have increased in the 1978-89 period. As discussed earlier, the literature suggests that government agencies and attorneys may have greater stakes or greater legal sophistication than their private counterparts. If this is true, a decrease in the proportion of race discrimination suits initiated by the government over time might have reduced plaintiffs' overall stakes or sophistication, with the result of raising employers' relative stakes or sophistication. An increase in the proportion of suits against government defendants might have led to a similar result. Our data set reflects both of these phenomena. ${ }^{181}$ In addition, although the

${ }^{180}$ For an analogous explanation of how selection effects might account for declining success rates in other types of civil cases, see James A. Henderson, Jr. and Theodore Eisenberg, The Quiet Revolution in Products Liability, 37 UCLA L Rev 479, 504 (1990) (discussing selection effects in the context of product liability suits).

${ }^{281}$ In our data set, $46.5 \%$ of the early race discrimination cases involved the federal government as plaintiff, compared to only $10.0 \%$ of the modern race discrimination cases. In addition, only $16.3 \%$ of the early race discrimination cases involved government employers, compared to $30.0 \%$ of the modern race discrimination cases. See Table 6 . Because our data set involves published litigated cases, however, it is possible that these changes are attributable to the same sort of selection effects under consideration. If, for example, plaintiffs were equally likely to file suit against government employers in the early and more recent periods, but cases against such employers were more likely to be tried or published in the more recent period, our data set would show a higher level of government employer representation among the more recent cases. Thus, the $\mathrm{ABF}$ data set provides a more appropriate basis for determining whether such changes occurred. 
ABF sample includes too few cases involving government plaintiffs to test the first trend, ${ }^{182}$ the sample reflects the second trend. Among filed race discrimination cases in which the lack of interest argument was a potential defense, the proportion of cases involving government employers rose from 22.2 percent (10 out of 45) of those filed between 1972 and 1977 to 33.3 percent (5 out of 15) of those filed between 1978 and 1987.

Other data from the ABF sample, however, suggest that selection effects do not account for the decline in race discrimination plaintiffs' success rates. According to the selection effects explanation, race discrimination plaintiffs' success rates declined because employers began to settle a greater proportion of race discrimination cases, including a disproportionate number of cases that were strong for plaintiffs. In the ABF sample, however, race discrimination cases actually became slightly less likely to settle in the more recent period. Whereas 53.3 percent (20 out of 45 ) of the race discrimination cases filed between 1972 and 1977 settled, only 46.7 percent ( 7 out of 15 ) of the race discrimination cases filed between 1978 and 1987 settled. The more recent race discrimination cases were less likely to reach trial: 15.6 percent ( 7 out of 45 ) of the cases filed in the earlier period reached trial, while only 6.7 percent ( 1 out of 15) of the cases filed in the more recent period did so. This result did not occur because the more recent race discrimination cases were more likely to settle, however, but because the courts were more likely to grant pre-trial motions dismissing them on the merits. In the early period, the courts granted such motions in only 11.1 percent ( 5 out of 45 ) of the cases, as compared to 26.7 percent (4 out of 15) of the recent cases. ${ }^{183}$ Thus, plaintiffs experienced declining success at the pre-trial motion stage as well as the trial stage.

To the extent that these trends from the small ABF sample accurately represent trends among all filed race discrimination cases in which the lack of interest argument was a potential de-

${ }^{182}$ There is only one race discrimination case involving a government plaintiff in the ABF sample.

${ }_{183}$ The category of cases dismissed on the merits before trial includes cases dismissed on summary judgment, cases dismissed for failure to state a claim for which relief may be granted, and cases dismissed for other non-procedural reasons. In addition to being settled, tried, or dismissed on the merits, some cases were dropped by plaintiffs and, in others, the disposition was unknown. In the 1972-77 period, 24 cases settled, seven reached trial, five were dismissed on the merits, eight were dropped, and the remaining case was of unknown disposition. In the 1978-87 period, seven cases settled, one reached trial, four were dismissed on the merits, two were dropped, and the remaining case was of unknown disposition. 
fense, the trends undermine the selection effects explanation. Even accounting for settlement rates and assuming that settlements benefitted plaintiffs, race discrimination plaintiffs fared worse in the modern period than in the earlier period. In the more recent period, employers have not pushed to settle more cases, but instead have contested and won more cases on pre-trial motions. That the courts have dismissed more cases before trial may suggest that they adopted legal standards that are less favorable to plaintiffs than their earlier standards. ${ }^{184}$

As noted earlier, however, both a shift toward less favorable judicial attitudes and a shift toward weaker cases could have contributed to the decline in race discrimination plaintiffs' success rates. The next Section attempts to sort out these explanations by evaluating the relative strength of early and modern race discrimination cases in our data set. Our methodology is similar to that employed in our earlier comparison of the strength of the race and sex discrimination cases.

B. A Comparison of the Content of Early and Modern Race Discrimination Cases

To sort out the causes of the decline in plaintiffs' success rates in race discrimination cases, we first assume that the courts did not alter their approach to the lack of interest argument. We then analyze the proportion of the decline that may be accounted for by shifts in the content of the cases alone. Columns two and three of Table 6 show the means (or the percentage of cases in which that factor was present) for the evidence and other independent variables in race discrimination cases decided in the 1967-77 and 197889 periods, respectively.

To evaluate the importance of the changes in the composition of the cases over time, we conducted a decomposition analysis, which quantifies the amount of the decline in plaintiffs' success rates that may be attributed to changes in the means for each variable. The last column of Table 6 shows the percentage of the decline that can be explained by changes in the means for each variable, assuming that the effect of the variables on plaintiffs' likelihood of winning remained constant across both time periods. Because the degree to which the change in a variable contributed

\footnotetext{
184 See Henderson and Eisenberg, 37 UCLA L Rev at 530-32 (cited in note 180) (suggesting that if a decline in plaintiffs' success in products liability cases is attributable to a shift toward new, more pro-defendant legal standards, one would expect an increase in the rate at which district courts dismiss cases on pre-trial motions).
} 
to the decrease in success rates is a function of both the difference in the mean for the variable across periods and the effect of that variable on case outcome, the analysis weights the difference in variable means across periods with the coefficients from our earlier full logit model for the race cases (Table 4, column 2). ${ }^{185}$ A positive percentage indicates that the shift in the mean for the variable contributed to the decline in plaintiffs' success; the larger the value, the greater the proportion of the decline that is accounted for by the shift in the mean for that variable.

185 The percentages in column three were calculated in two steps. First, we calculated the components of change by subtracting the variable means for the 1967-77 period from the variable means for the $1978-89$ period. Then we weighted these differences by the corresponding logit coefficient from Table 4, column 2. The component of change for the evidence of past discrimination variable, for example, is equal to $(0.550-0.884) \times 2.405=$ -0.803 . Second, to calculate the percentage of the decline in success rates attributable to changes in the means of the variables across periods, we divided the component of change figures by the total change across periods in the predicted log odds of plaintiffs' success (the sum of the components of change). The total estimated change of the log odds is equal to -4.129 , so the proportion of the decline in plaintiffs' success rate that can be accounted for by the decline in the percentage of cases in which evidence of past discrimination is present, for instance, is equal to $-0.803 /-4.129=.194$ or 19.4 percent.

For an example of a similar decomposition analysis which uses the coefficients from logistic regressions to compute the components of change in marriage rates between 1960 and 1980 for different ages, races, and sexes, see Robert D. Mare and Christopher Winship, Socioeconomic Change and the Decline of Marriage for Blacks and Whites, in Jencks and Peterson, eds, The Urban Underclass at 175, 201-02 (cited in note 24). 
TABLE 6: Variables Means for Early and Modern Race Discrimination Cases and Decomposition of Change in Success Rates Attributable to

Changes in Variables

\begin{tabular}{lccc}
\hline \multicolumn{1}{c}{ Variables } & \multicolumn{2}{c}{ Variable Means } & Decomposition \\
\hline & $\begin{array}{l}1967-1977 \\
(\mathrm{n}=43)\end{array}$ & $\begin{array}{c}1977-1989 \\
(\mathrm{n}=20)\end{array}$ & $\begin{array}{c}\text { Percentage of } \\
\text { the Decline in } \\
\text { Success Rates }\end{array}$ \\
& & & $\begin{array}{c}\text { Accounted for } \\
\text { by Changes in } \\
\text { Variable Mean }\end{array}$ \\
Evidence of Past & $88.4 \%$ & $55.0 \%$ & $19.4 \%$ \\
Discrimination & & $55.0 \%$ & $-0.3 \%$ \\
Direct or Anecdotal & $62.8 \%$ & $50.0 \%$ & $8.8 \%$ \\
Evidence & $41.9 \%$ & $20 \%$ & $8.8 \%$ \\
Special Efforts & $11.6 \%$ & $20.0 \%$ & $6.7 \%$ \\
Formal Recruiting & $69.8 \%$ & $60.0 \%$ & \\
Subjective Selection System & & & \\
\hline
\end{tabular}

Percentage of Decline

Accounted for by Changes

in the Evidence

$43.4 \%$

\begin{tabular}{llll}
\hline Blue-Collar Work & $90.7 \%$ & $70.0 \%$ & $15.8 \%$ \\
Government Plaintiff & $46.5 \%$ & $10.0 \%$ & $-6.9 \%$ \\
Government Defendant & $16.3 \%$ & $30.0 \%$ & $-14.5 \%$ \\
Disparate Impact Analysis & $88.4 \%$ & $25.0 \%$ & $16.6 \%$ \\
\hline
\end{tabular}

Percentage of Decline

Accounted for by Changes

in Non-Evidentiary Factors

$11.0 \%$

Unexplained Decline

$45.6 \%$

Total

$100.0 \%$

Assuming that judges continued to evaluate the evidence the same way in the early and modern periods, the evidentiary strength of race discrimination cases has weakened somewhat over time. The most significant shift occurred in connection with evidence of past discrimination: plaintiffs were far less likely to introduce this type of evidence in the 1978-89 period than in the 1967- 
77 period. This change does not seem surprising. To the extent that employers tended to eliminate the more blatant forms of discrimination in the late 1960s and early 1970s, fewer employers may have had recent histories of extreme segregation in the modern period. Plaintiffs may have had to go back farther in time to uncover such patterns. Not only would such remote patterns be more difficult to document; judges would probably perceive the patterns as less probative than more recent records of discrimination. As a result, plaintiffs may have become less likely to proffer such evidence. In addition, employers may have pushed harder to settle cases in which plaintiffs had gathered evidence of past discrimination, because they realized that this evidence greatly strengthened plaintiffs' likelihood of winning. To the extent that the courts have continued to rely heavily on evidence of past discrimination to reject the lack of interest argument, the reduced incidence of this type of evidence would have weakened plaintiffs' chances of prevailing in the modern period considerably. In our decomposition analyses, this factor contributed more than any other factor to the decline in plaintiffs' success rate, accounting for 19.4 percent of the decline.

Interestingly, in the more recent period, employers were less likely to claim that they had made special efforts to attract minorities. To those who believe employers have become more committed to affirmative action with the passage of time, this result may seem surprising. As noted earlier, however, it is possible that employers who are sued do not represent all employers. Employers who failed to implement affirmative action measures may have been considered easier targets for lawsuits in the modern period. ${ }^{186}$ In addition, given that claims of special efforts tended to arouse judicial suspicion in the early period, employers may have realized over time that this evidence was not worth pursuing. Instead, they may have turned their attention to producing evidence of formal recruiting, which was present in a greater proportion of the more recent cases. In our earlier logit results, evidence of formal recruiting significantly improved employers' chances of winning (Table 4, row 5, columns 2 and 4), while claims of special efforts had the opposite effect (Table 4, row 4, columns 2 and 4). Thus, perhaps ironically, employers could enhance their prospects of prevailing

\footnotetext{
${ }^{188}$ Conversely, in the earlier period, larger employers may have been targeted by the government or civil rights organizations for purposes of demonstration. See Jonathan S. Leonard, The Effectiveness of Equal Employment Law and Affirmative Action Regulation, 8 Res in Lab Econ 319, 340-41 (1986).
} 
by backing off their allegations of affirmative action measures and beefing up their allegations of neutral recruiting measures. In our decomposition, each of these shifts contributed equally ( 8.8 percent) toward the decline in plaintiffs' success.

The remaining evidence variables manifested only minor differences across time periods. The more recent cases were slightly less likely to involve subjective selection systems than the earlier cases. Assuming that the employers' use of subjective criteria continued to strengthen the inference of discrimination in the more recent era, the shift toward more objective systems contributed a modest 6.7 percent of the decline in plaintiffs' success rates. The more recent cases were also slightly less likely to involve direct or anecdotal evidence of discrimination than the earlier cases. Because the courts attach so little significance to this type of evidence in race discrimination cases, plaintiffs may have decided to forego the trouble and expense of compiling this proof. In fact, in our logit models, direct or anecdotal evidence tended to decrease plaintiffs' likelihood of prevailing in race discrimination cases rather than increasing it. Insofar as this evidence continued to have a negative effect, its reduced incidence served to strengthen rather than weaken the more recent race discrimination cases.

The variables relating to the parties showed some substantial changes across time periods. Federal government participation on the side of plaintiffs plummeted in the 1978-89 period. This result is consistent with the trend for published appellate employment discrimination cases, in which the proportion of race discrimination cases initiated by the federal government has declined substantially over time. ${ }^{187}$ Perhaps the federal government shifted its focus away from classwide race discrimination cases in the late 1970 s or early $1980 \mathrm{~s} ;{ }^{188}$ evidence shows that the Reagan administration backed away from the previous federal commitment to dismantling racial segregation. ${ }^{189}$ Our logit analysis revealed that other factors being equal, government plaintiffs fared slightly

187 In Burstein's study of all federal appellate employment discrimination cases published between 1965 and 1985, federal government participation in race discrimination cases declined steadily over time. See Burstein, $96 \mathrm{Am}$ J Soc at 1217-18 (cited in note 75).

188 See id at 1218 ("Perhaps the federal government focused special efforts in the early years on race discrimination cases and major 'pattern or practice' cases, . . . but has shifted its focus in recent years.").

${ }^{280}$ See, for example, Leonard, $4 \mathrm{~J}$ Econ Persp at 58-59 (cited in note 172); Majority Staff of HR Committee on Education and Labor, A Report on the Investigation of the Civil Rights Enforcement Activities of the Office of Federal Contract Compliance Programs, U.S. Department of Labor, HR Rep No 100-R, 100th Cong, Ist Sess 40-41, 53-55 (1987). 
worse than private plaintiffs in cases addressing the lack of interest argument (Table 4, row 8 , column 2). Thus, perhaps counter-intuitively, if the courts continued to react negatively to government enforcement agencies across both time periods, the reduced presence of the federal government as a plaintiff would have increased rather than decreased plaintiffs' likelihood of winning in the more recent period.

While the level of government plaintiff participation decreased, the level of government defendant involvement increased over time. As we noted earlier, this same trend appears in the ABF sample, which makes it doubtful that the increased involvement of government employers in our data set is attributable to selection effects. In our logit models, after controlling for the content of the cases, plaintiffs fared significantly better against government employers than against private employers (Table 4, row 9, columns 2 and 4). Assuming that this effect continued into the 1978-89 period, the increased presence of government employers would have substantially improved plaintiffs' prospects of winning in the more recent period.

These gains for plaintiffs were offset by shifts in the nature of the work. Race discrimination plaintiffs were far more likely to be seeking white-collar work in the 1978-89 cases than in the 1967-77 cases. In our logit models, the courts were significantly more likely to rule in favor of race discrimination plaintiffs in cases involving blue-collar work than in cases involving white-collar work (Table 4, row 7 , columns 2 and 4 ). Once employers realized that the courts were more likely to reject the lack of interest argument in bluecollar cases than in white-collar cases, they may have begun to make greater efforts to settle blue-collar cases. Alternatively, the increased level of white-collar cases may reflect the larger patterns of desegregation that occurred in the wake of Title VII. Because African Americans and other minorities have made greater strides in obtaining blue-collar jobs than white-collar jobs, they may have begun to file suit more frequently to obtain the white-collar employment that has eluded them. Ironically, however, such a shift would have contributed to minorities' declining success. Assuming that the courts continued to respond less favorably to plaintiffs in white-collar cases in the modern period, the increased level of white-collar cases would have diminished plaintiffs' chances of winning substantially. In our decomposition analysis, this shift accounted for 15.8 percent of the decline in plaintiffs' success rates.

The shift away from disparate impact analysis produced the second largest change in plaintiffs' success rates, accounting for 
16.6 percent of the decline. Use of a disparate impact analysis dropped from an overwhelming 88.4 percent of the cases in the early period to only 25 percent of the cases in the modern period. This trend may be attributable in part to selection effects. If employers realized that a disparate impact framework benefitted plaintiffs more than a disparate treatment framework, they may have begun to offer more to settle cases that could be analyzed under a disparate impact framework. The decline in disparate impact cases probably also reflects changes in legal doctrine. Since the late 1970s, the courts have restricted the application of the disparate impact framework. In 1977, for example, the Supreme Court held that the disparate impact doctrine does not apply to seniority systems that perpetuate the effects of pre-Act hiring discrimination. ${ }^{180}$ In the early 1980 s, some courts of appeals also began to hold that the disparate impact doctrine does not apply to subjective employment systems. ${ }^{191}$ Although the Supreme Court eventually rejected this reasoning in $1989,{ }^{192}$ other decisions have limited the use of the disparate impact doctrine to cases in which plaintiffs can pinpoint the particular employment practices that caused their underrepresentation. ${ }^{193}$ Such developments have tended to force plaintiffs to challenge job segregation under a disparate treatment framework, which requires them to prove a nar-

${ }^{100}$ See Int'l Brotherhood of Teamsters v United States, 431 US 324, 353 n 38 (1977).

${ }^{103}$ See, for example, Pouncy v Prudential Ins. Co. of Am., 668 F2d 795, 801 (5th Cir 1982) (refusing to apply disparate impact analysis to a subjective promotional system or its various components, including failure to post job openings and the use of subjective employment evaluations); Talley $v$ United States Postal Service, 720 F2d 505, 506-07 (8th Cir 1982) (holding that disparate impact analysis was inapplicable to subjective decisionmaking by a predominantly white supervisory force); EEOC v Federal Reserve Bank of Richmond, 698 F2d 633, 639 (4th $\mathrm{Cir} 1983$ ), rev'd on other grounds, 467 US 867 (1984) (refusing to apply the disparate impact model where plaintiff failed to identify any "objective standard, applied evenly and automatically").

${ }^{102}$ See Watson v Fort Worth Bank \& Trust, 487 US 977, 990-91 (1988) (holding that challenges to subjective promotion systems may be analyzed under a disparate impact framework as well as a disparate treatment framework).

${ }^{103}$ Around the same time that some courts of appeals began to conclude that disparate impact analysis was inapplicable to subjective selection processes, some circuits also began to require disparate impact plaintiffs to prove that specific employment practices caused the disproportionate exclusion of protected class members. See, for example, Pouncy, 668 F2d at 801; Carroll v Sears, Roebuck \& Co., 708 F2d 183, 189 (5th Cir 1983); Griffin v Bd. of Regents of Regency Universities, 795 F2d 1281, 1288-89 (7th Cir 1986). The Supreme Court adopted this reasoning in Wards Cove. See Wards Cove Packing Co. $v$ Atonio, 490 US 642, 657 (1989) (" $\mathrm{A}]$ plaintiff must demonstrate that it is the application of a specific or particular employment practice that has created the disparate impact under attack. Such a showing is an integral part of the plaintiff's prima facie case in a disparate-impact suit under Title VII."). 
row definition of discriminatory intent. ${ }^{184}$ Our logits confirmed that plaintiffs fare far worse under a disparate treatment analysis than under a disparate impact analysis (Table 4, row 10). Assuming that this trend held across both time periods, courts' decreased use of the disparate treatment framework would have contributed substantially to reduced race discrimination plaintiffs' success after 1977.

Although the race discrimination cases decided in the 1978-89 period are somewhat weaker than their 1967-77 counterparts, weaker evidence alone cannot explain the dramatic reduction in plaintiffs' success rates in the more recent period. As our decomposition analysis shows, shifts in the incidence of all five types of evidence account for less than half (43.4 percent) of the decline in plaintiffs' success rates in the 1978-89 period. Shifts in the nonevidentiary variables, which do not necessarily imply any weakening of the more recent cases, do not account for the remaining decline in plaintiffs' success. Taken together, changes in the evidentiary and non-evidentiary factors account for only around half (54.4 percent) of the decline. This result is consistent with the results of our earlier logit analyses. The coefficient for the date variable in our full race model showed that even after controlling for all the evidentiary and non-evidentiary factors simultaneously, plaintiffs were substantially less likely to prevail in the more recent period than in the earlier period (Table 4, row 11, column 2). In our parsimonious model, this difference was highly significant (Table 4, row 11, column 4).

So far, our analyses have assumed that the courts have not altered their standards for evaluating the lack of interest argument in race discrimination cases over time. That plaintiffs won less frequently even in cases with similar characteristics suggests, however, that the courts began to respond to the evidence in a manner less favorable to plaintiffs in the more recent period. Particularly if judges began to believe that racial discrimination posed a less serious social problem, they may have become more inclined to accept the lack of interest argument even in strong cases in which they would have rejected this argument in the earlier era. If so, our characterization of the cases as having become weaker due to shifts in the evidence may be overstated. Some types of evidence that

106 In the late $1970 \mathrm{~s}$, the Supreme Court decided a series of constitutional cases that adopted a narrow definition of discriminatory intent. See Washington v Davis, 426 US 229, 242 (1976); Arlington Heights v Metro. Housing Dev. Corp., 429 US 252, 264-66 (1977); Personnel Admin. of Massachusetts v Feeney, 442 US 256, 279 (1979). 
significantly increased plaintiffs' likelihood of winning in the earlier period may have become less powerful predictors of success in the modern period. As a result, these types of evidence may have become less prevalent in the modern cases not because the nature of employers' underlying practices or the composition of filed cases selected for litigation changed, but instead because plaintiffs realized that these types of evidence had become less beneficial and pursued them less frequently in the modern period. Plaintiffs may have won less frequently not because they failed to introduce evidence that judges considered strong under the old standards-but because judges became more inclined to accept the lack of interest explanation in cases that would have been considered strong in the earlier era.

C. A Comparison of Judicial Approaches to the Lack of Interest Defense in Early and Modern Race Discrimination Cases

Our analyses confirm that a shift in judicial attitude and approach has occurred in race discrimination cases. Although there are too few cases in the 1978-89 period to permit us to run separate logistic regression models for the early and modern race discrimination cases, we present alternative comparisons of plaintiffs' success rates in cases with the same types of evidence. Table 7 shows plaintiffs' success rates in the 1967-77 and 1978-89 periods in cases with every combination of the evidence that is present in the race discrimination cases in our data set. 
TABLE 7: Comparison of Plaintiff's' Success Rates in Early and Modern Race Discrimination Cases With the Same Combinations of Evidence

\begin{tabular}{|c|c|c|c|c|c|c|c|}
\hline \multirow[b]{2}{*}{1.} & \multirow{2}{*}{$\begin{array}{c}\begin{array}{c}\text { Evidentiary } \\
\text { Combinations }\end{array} \\
\mathrm{W}+\mathrm{S}+\mathrm{E}+\mathrm{A}+\mathrm{D}\end{array}$} & \multirow{2}{*}{$\begin{array}{c}\begin{array}{c}\text { Success Rate in } \\
\text { 1967-77 Period }\end{array} \\
100.0 \%\end{array}$} & \multicolumn{2}{|c|}{$\begin{array}{c}\text { Cumulative } \\
\text { Success Rate in } \\
\text { 1967-77 Period }\end{array}$} & \multirow{2}{*}{$\begin{array}{c}\text { Success Rate in } \\
\text { 1978-89 Period }\end{array}$} & \multicolumn{2}{|c|}{$\begin{array}{l}\text { Cumulative } \\
\text { Success Rate in } \\
\text { 1978-89 Period }\end{array}$} \\
\hline & & & $100.0 \%$ & $(8 / 8)$ & & $100.0 \%$ & $(1 / 1)$ \\
\hline 2. & $W+S+E+A$ & $100.0 \%$ & $100.0 \%$ & $(12 / 12)$ & - & $100.0 \%$ & $(1 / 1)$ \\
\hline 3. & $W+S+E+D$ & $100.0 \%$ & $100.0 \%$ & $(23 / 23)$ & $100.0 \%$ & $100.0 \%$ & $(4 / 4)$ \\
\hline 4. & $W+E+A$ & $100.0 \%$ & $100.0 \%$ & $(24 / 24)$ & - & $100.0 \%$ & $(4 / 4)$ \\
\hline 5. & $W+S+D$ & - & $100.0 \%$ & $(24 / 24)$ & $100.0 \%$ & $100.0 \%$ & $(5 / 5)$ \\
\hline 6. & A only & $100.0 \%$ & $100.0 \%$ & $(25 / 25)$ & $100.0 \%$ & $100.0 \%$ & $(6 / 6)$ \\
\hline 7. & $W+S+E$ & $100.0 \%$ & $100.0 \%$ & $(29 / 29)$ & $50.0 \%$ & $87.5 \%$ & $(7 / 8)$ \\
\hline 8. & $W+E$ & $100.0 \%$ & $100.0 \%$ & $(31 / 31)$ & $50.0 \%$ & $80.0 \%$ & $(8 / 10)$ \\
\hline 9. & $W+E+A+D$ & $100.0 \%$ & $100.0 \%$ & $(33 / 33)$ & $0.0 \%$ & $72.7 \%$ & $(8 / 11)$ \\
\hline 10. & S only & $100.0 \%$ & $100.0 \%$ & $(34 / 34)$ & $0.0 \%$ & $66.7 \%$ & $(8 / 12)$ \\
\hline 11. & $W+E+D$ & $75.0 \%$ & $97.4 \%$ & $(37 / 38)$ & $0.0 \%$ & $57.1 \%$ & $(8 / 14)$ \\
\hline & All Others & $0.0 \%$ & $86.0 \%$ & $(37 / 43)$ & $0.0 \%$ & $40.0 \%$ & $(8 / 20)$ \\
\hline
\end{tabular}

$\mathrm{W}=$ No Formal Recruiting; $\mathrm{S}=$ Subjective System;

$E=$ Evidence of Past Discrimination; $A=$ Special Efforts;

$\mathrm{D}=$ Direct or Anecdotal Evidence of Discrimination

\section{The change in approach.}

This analysis illustrates the courts' changing reactions to the evidence in race discrimination cases. Since the late 1970s, judges have become more likely to accept the lack of interest argument even in strong cases in which they would have rejected it in the earlier era. In the 1967-77 period, the courts treated the first ten combinations of evidence as a compelling basis for rejecting the lack of interest argument. Plaintiffs won 100 percent of the cases involving these types of evidence (Table 7 , row 10, column 3). In the 1978-89 period, however, plaintiffs' combined success rate fell to 66.7 percent in cases with these same combinations of evidence (Table 7, row 10, column 5). There was only one other pattern of evidence in which plaintiffs won any cases in either period, and including this eleventh pattern in the analysis yields similar results. In the early period, courts rejected the lack of interest argu- 
ment in 97.4 percent of all cases with these eleven combinations of evidence combined (Table 7, row 11, column 3). By contrast, in the more recent period, courts rejected this argument in only 57.1 percent of such cases (Table 7, row 11, column 5). Thus, even in cases that involved the very same types of evidence, judges were significantly less likely to attribute racial segregation to employer discrimination in the more recent period than in the earlier era.

A close reading of judicial opinions confirms the change in judicial perceptions of job segregation. The opinions reveal a profound shift in judges' attitudes toward statistical evidence, which signals a change in their underlying assumptions about the causes of job segregation. In the initial decade of Title VII enforcement, the courts presumed that patterns of job segregation revealed by statistical evidence were attributable to discrimination. Judges relied heavily on statistical evidence to "uncover clandestine and covert discrimination by the employer or union involved." 195 The judicial faith in statistical evidence was reflected in the oft-repeated aphorism: "[S]tatistics often tell much, and Courts listen." ${ }^{\text {"196 }}$ Indeed, in this early era, there was "virtual unanimity on the proposition that the statistical absence of blacks disproportionate to whites makes out a Title VII . . . violation."197

Since the late 1970s, however, judicial rhetoric about statistical evidence has changed dramatically. The courts now express considerable skepticism about its probative value. ${ }^{198}$ Some courts have gone so far as to question whether statistical proof even suffices to establish a prima facie case of discrimination. ${ }^{189}$ Contrary

\footnotetext{
19s See Int'l Brotherhood of Teamsters v United States, 431 US 324, 339-40 n 20 (1977) (citing early courts of appeals decisions making this point).

190 This phrase apparently was first used in State of Alabamav United States, 304 F2d 583,586 (5th Cir 1962), a voter registration case. Judges quickly borrowed and repeated it in Title VII cases to emphasize the value of statistical evidence for uncovering patterns of racial segregation in the labor market. See, for example, United States $v$ Ironworkers Local 86, 443 F2d 544, 551 (9th Cir 1971); Parham v Southwestern Bell Tel. Co., 433 F2d 421, 426 (8th Cir 1970); Jones v Lee Way Motor Freight, Inc., 431 F2d 245, 247 (10th Cir 1970); Sagers v Yellow Freight Sys., Inc., 388 F Supp 507, 515 (N D Ga 1973).

${ }^{207}$ Stamps v Detroit Edison Co., 365 F Supp 87, 109 (1973), rev'd on other grounds 515 F2d 301 (6th Cir 1975) (citing early cases). One court held "as a matter of law that these statistics, which revealed an extraordinarily small number of black employees, except for the most part as menial laborers, established a violation of Title VII ...."Parham, 433 F2d at 426.

198 See, for example, Eubanks v Pickens-Bond Constr. Co., 635 F2d 1341, 1347 (8th Cir 1980) (citing Teamsters, 431 US at 340 , for the proposition that the usefulness of statistics "depends on all of the surrounding facts and circumstances"); Croker v Boeing Co., 662 F2d 975, 995 (3d Cir 1981) (en banc) (same).

${ }^{109}$ See, for example, Hilton v Wyman-Gordon Co., 624 F2d 379, 381 n 1 (1st Cir 1980). See also Eubanks, $635 \mathrm{~F} 2 \mathrm{~d}$ at 1351 (suggesting that plaintiffs failed to make a prima facie
} 
to the earlier judicial confidence in statistical evidence, the modern mood is captured in strong warnings about its shortcomings. "We again warn plaintiffs that their statistical evidence should show more than a racial imbalance in the workforce, but should prove that the [specific] practices result in discrimination."200 "[Statistics] which purport to demonstrate a predominance of blacks in less desirable positions may reflect imbalances but do not show that race ... cause[d] the imbalances, and are thus of little probative value."201

As many judges have noted in dissent, the courts' changed attitude toward statistical evidence reflects a shift in their underlying assumptions about the prevalence of racial discrimination in the workplace. Judges have become less willing to infer that "race caused the imbalances," in part because they believe that racial discrimination is no longer sufficiently common to support such an inference. ${ }^{202}$ The lack of interest argument provides an alternative explanation for segregation that conforms to popular stereotypes about minorities' "lack of motivation." have become more likely to accept the lack of interest argument across a wide range of evidentiary patterns that they once treated as powerful refutations of this argument. As part of this general pattern, judges have begun to attach less importance to each individual type of evidence that they relied on to dismiss the lack of interest argument in the earlier era.

The Fourth Circuit's 1978 decision in Lewis v Tobacco Workers' International Union ${ }^{204}$ provides a powerful example of the

case in part because they failed to supplement their statistical proof with "evidence of specific instances of discrimination").

${ }^{200}$ Carroll v Sears, Roebuck \& Co., 708 F2d 183, 195 (5th Cir 1983).

${ }^{201}$ Harris $v$ Marsh, 45 FEP (BNA) 1037, 1043 (E D NC 1983).

${ }^{202}$ See, for example, Eubanks, $635 \mathrm{~F} 2 \mathrm{~d}$ at 1352, 1356 (McMillian dissenting from the majority's holding that plaintiffs' statistical evidence did not suffice to show racial discrimination in promotions, and criticizing the majority for "[c]onsidering each single promotion decision separately and considering the whole pattern in isolation from the persuasive national experience of racial discrimination in employment that gave rise to the need for Title VII"). See also Wards Cove, 490 US at 661 (Blackmun dissenting) ("One wonders whether the majority still believes that race discrimination-or, more accurately, race discrimination against non-whites-is a problem in our society ...."); City of Richmond v J.A. Croson Co., 488 US 469, 552 (1989) (Marshall dissenting) (noting that the majority's invalidation of a minority set-aside program "signals that it regards racial discrimination as largely a phenomenon of the past, and that government bodies need no longer preoccupy themselves with rectifying racial injustice").

${ }^{203}$ See, for example, Kluegel, 28 Am Behav Scientist at 767-78 (cited in note 24).

204577 F2d 1135 (4th Cir 1978), vacating and remanding Lewis v Philip Morris, Inc., 419 F Supp 345 (E D Va 1976). 
shift in judicial attitudes and approach. Until the early 1960s, the cigarette manufacturer Phillip Morris had practiced overt discrimination, restricting African Americans to seasonal, unskilled work processing tobacco in the stemmery department and prohibiting them from the higher-paying, permanent jobs in other departments. The plaintiffs alleged that after Title VII took effect, the company merely switched to a covert system of discrimination and continued to assign African Americans disproportionately to the stemmery. The evidence showed that from 1964 to 1974, over fifty percent of all new African American employees were hired for the stemmery, compared to only eleven percent of the new white employees. In fact, as late as 1974, ninety-five percent of all stemmery workers were African American. ${ }^{205}$

Phillip Morris sought to explain these disparities by appealing to racial differences in work preferences. After presenting evidence that African Americans constituted ninety-five percent of the applicants to the stemmery, the company argued that it had not discriminated in job assignment but had merely honored African Americans' preference for stemmery jobs. ${ }^{206}$ When the district judge inquired as to why they would be more willing than whites to accept less desirable jobs, the company responded: "[B]lacks work in the Stemmery because they prefer the work demands there or are willing to work there, while whites are unwilling to accept that work."207

The district judge refused to accept this explanation. The judge concluded that African Americans had applied disproportionately for the stemmery because the company's extended history of discrimination had led them to believe it would be futile to seek jobs in the higher-paying departments. ${ }^{208}$ Invoking the wellestablished principle that an employer with a history of discrimi-

\footnotetext{
${ }^{205}$ Lewis, 577 F2d at 1137, 1142.

208 Lewis, 419 F Supp at 354-55.

207 Id at 355.

${ }^{208}$ The district judge stated:

Phillip Morris' history of segregated departments, and the continued dominance of blacks in the traditionally black departments, has led a substantial number of the blacks applying to Phillip Morris for work to the understanding that their most likely opportunity for employment would be in the Stemmery. It is not surprising that the lines to the Stemmery hiring office are populated with aspiring black workers, nor is it surprising that blacks may, in interviewing, express a preference for Stemmery work. It appears to a substantial number of black applicants that they either take a Stemmery job or look for work with another employer. Given this background, any. notion of "preference" is meaningless; to prefer one alternative to another, one must believe that both alternatives are available.
}

Id at 356 . 
nation has a duty to overcome the chilling effects of its prior discrimination, the district judge held the company liable and directed it to take steps to welcome African Americans into the more lucrative departments. ${ }^{208}$

The Fourth Circuit reversed. In the Fourth Circuit's analysis, the question was not whether Phillip Morris had a duty to eliminate the chilling effects of its own past discrimination, but instead whether the company's failure "to announce [its present] innocence is a violation of Title VII." ${ }^{110}$ According to the Fourth Circuit, "[t]he question [was] whether or not the company did in fact discriminate, not whether or not the [Black] employee[s] did in fact believe the company had discriminated."211 Because African Americans populated departments other than the stemmery at rates at least approximating their proportion of the local labor market, the court concluded that there was no racial discrimination (or even racial disparity). ${ }^{212}$ Using the local labor market as the basis for comparison obscured the real problem, however, for the record clearly indicated that African Americans who sought work at Phillip Morris were far more likely than whites to be hired for the stemmery and not the better-paying departments. ${ }^{213}$ By ignoring this evidence and treating the stemmery as a separate labor market, the court of appeals converted the record from one in which Phillip Morris had systematically relegated African Americans to the most menial jobs into one in which they held a baseless belief that the company would not consider them fairly for more desirable jobs.

As an additional ground for reversal, the Fourth Circuit held that the district court had erred in finding that African Americans even felt discouraged from pursuing the higher-paying jobs. Although a witness testified that Phillip Morris's practices led substantial numbers of African Americans to believe it would be futile to pursue such employment, the court of appeals dismissed her testimony on the ground that she herself had not been dissuaded from seeking work in a predominantly white department. ${ }^{214}$ The court emphasized that "not a single other witness testified that he had been discouraged by belief or otherwise from applying for

${ }^{200}$ See id at 356-58.

210 Lewis, 577 F2d at 1143.

211 Id.

212 Id at 1142.

${ }^{213}$ Lewis, 419 F Supp at 353-54, 355-56.

214 Lewis, 577 F2d at 1143. Ironically, the company had rejected the witness when she applied for that department, and hired her only when she applied for work in the stemmery. 
work in one of the permanent departments. . .."215 In the absence of such an explanation, only Phillip Morris's lack of interest argument remained to account for the patterns of racial segregation in departmental placement.

The Fourth Circuit's reversal in Lewis reflects the larger transformation in judges' understanding of job segregation that began in the late 1970s. The most fundamental change has occurred in judges' perception of the relevance of historical context, as revealed by their reactions to evidence of past discrimination. In the early period, the courts treated proof of past discrimination as dispositive. Judges presumed that minorities' failure to apply for traditionally segregated jobs reflected a sense of futility created by past discrimination rather than an inherent lack of interest in the work. As a corollary, courts imposed on employers with a history of segregation a duty to overcome their "reputation for discrimination" by attracting minorities to historically segregated jobs. ${ }^{216}$ This approach held employers responsible for the continuing legacy of labor market discrimination rather than its victims. ${ }^{217}$

The approach in Lewis stands this early reasoning on its head. In contemporary decisions, the historical context of discrimination has become irrelevant. Not only is the era of discrimination assumed to be over; it is almost as though it never existed. The courts now assume that the employer's past discrimination had no role in influencing minorities' work preferences and no role in contributing to current patterns of job segregation. Indeed, the causation is reversed: it is minorities' perceptions and preferences that have led to the segregation. Because the company no longer discriminates, it is irrational for minority workers to believe that the company would refuse to consider them equally for traditionally segregated jobs. Thus, even after insisting on anecdotal evidence, ${ }^{218}$

215 Id.

216 See, for example, United States v Lee Way Motor Freight, Inc., 7 FEP (BNA) 710, 748-49 (W D Okla 1973); United States v Central Motor Lines, 338 F Supp 532, 561-62 (W D NC 1971).

${ }^{217}$ For a powerful illustration of this perspective, see Morrow v Crisler, 491 F2d 1053, 1056-57 (5th Cir 1974) (en banc) ("[W]e are not sanguine enough to be of the view that benign recruitment programs can purge in two years a reputation which discriminatory practices of approximately 30 years have entrenched in the minds of blacks in Mississippi. ... Imaginative initiative is needed from all present members of the Highway Patrol.").

${ }^{218}$ For cases other than Lewis that suggest that the courts have placed greater emphasis on anecdotal evidence of discrimination in the modern period, see Eubanks, 635 F2d at 1351 (reversing the district court's finding of discrimination in promotion in part because "the plaintiff class did not bolster its case with any evidence of specific instances of discrimination"); Hilton v Wyman-Gordon Co., 624 F2d 379, 381 n 1 (1st Cir 1980) (suggesting that 
modern courts may refuse to credit minority witnesses' testimony that the employer's record discouraged them from applying unless the witnesses can identify specific incidents of discriminatory treatment to validate their "subjective belief[s]." new world, the very concept that an employer might have a "reputation for discrimination" has become an anomaly;220 the present is presumed to be a sharp break with the past. As a result, evidence of past discrimination alone no longer carries as much weight as it once did in persuading judges to reject the lack of interest argument, as Table 8 shows. ${ }^{221}$

statistical evidence alone may be insufficient to make a prima facie case, in the absence of anecdotal evidence to support the inference of discrimination).

${ }_{219}$ Lewis, 577 F2d at 1143. See also EEOC $v$ Sheet Metal Workers Int'l Ass'n, Local No. 122, 463 F Supp 388, 427 (D Md 1978) ("The [] testimony by black sheet metal workers in the building trade does not disclose any specific actions taken by Local 122 . . to discourage black journeymen from applying to Local $122 . .$. . [T] not shown ... that [] Local 122 has a general reputation for racial discrimination among black sheet metal workers . . . , although plaintiff has shown specific individuals who believed Local 122 to discriminate on the basis of race.").

${ }^{220}$ See, for example, Sheet Metal Workers, Local 122, 21 FEP (BNA) at 962-65 (questioning the relevance of a union's reputation for discrimination to the determination of liability).

221 The analyses in Table 8 examine the effect on case outcomes of each factor in isolation, without controlling simultaneously for the other evidence and facts presented. As stated above, our sample size was too small to permit us to estimate separate logistic regression models for the early and modern race cases that controlled simultaneously for all nine of our independent variables. We were, however, able to estimate separate logit models that controlled simultaneously for all five of the evidence variables; the results are consistent with the results for the evidence variables reported in Table 8 . In the logit model for the early race cases, the coefficients for evidence of past discrimination, formal recruiting, and subjective selection system were all large, positive, and significant at .10 or less. In the model for the modern race cases, by contrast, the coefficients for each of these three variables decreased in size and significance; none remained significant at .10 or less. 
TABLE 8: Plaintiffs' Success Rates in Early and Modern Race Discrimination Cases With Selective Characteristics

\begin{tabular}{lrr}
\hline Variables & $1967-77$ & $1978-89$ \\
\hline Evidence of Past & & \\
Discrimination & & \\
Yes & $92.1 \%$ & $54.5 \%$ \\
$\quad$ No & $40.0 \%$ & $22.2 \%$ \\
Formal Recruiting & & \\
Yes & $40.0 \%$ & $25.0 \%$ \\
$\quad$ No & $92.1 \%$ & $43.8 \%$ \\
Subjective Selection & & \\
System & & \\
Yes & $93.3 \%$ & $50.0 \%$ \\
$\quad$ No & $69.2 \%$ & $25.0 \%$ \\
Job-Type & & \\
Blue-Collar & $84.6 \%$ & $57.1 \%$ \\
$\quad$ White-Collar & $100.0 \%$ & $0.0 \%$ \\
Doctrinal Analysis & & \\
Disparate Treatment & $100.0 \%$ & $26.7 \%$ \\
$\quad$ Disparate Impact & $84.2 \%$ & $80.0 \%$ \\
\hline
\end{tabular}

Table 8 reveals that in the more recent period, the courts have also begun to accord less weight to the other types of evidence and facts that they relied on to reject the lack of interest argument in the earlier period. Before the late 1970s, courts presumed that informal, word-of-mouth-recruiting systems excluded minorities from the network of job opportunity. "With an almost completely white work force, it is hardly surprising that such a system of recruitment produced few, if any, black applicants. As might be expected, existing white employees tended to recommend their own relatives, friends and neighbors, who would likely be of the same race." 222 As a result, employers who failed to establish that they had implemented formal recruiting programs-and who therefore presumably relied on word-of-mouth recruiting-were significantly less likely to persuade judges to accept the lack of interest argument than employers who had adopted formal programs. In the more recent period, however, whether the employer had adopted a formal recruiting system made a smaller difference to the outcome: the courts were almost as likely to accept the lack of interest argument from employers who relied on word-of-mouth recruiting as from employers who had attempted to disseminate job information

${ }^{222}$ Parham v Southwestern Bell Tel. Co., 433 F2d 421, 427 (8th Cir 1970). 
to minorities and whites on a more equal basis. Thus, over time, judges have become less inclined to attribute minorities' failure to seek out higher-paying jobs to employers' racially exclusionary recruiting practices. ${ }^{223}$ Remarkably, some judges have even failed to interpret the use of nepotistic preferences as a race-related barrier. ${ }^{224}$

Evidence that the employer used a subjective selection system also benefitted plaintiffs less in the modern period. In the early period, courts concluded that "procedures which depend almost entirely upon the subjective evaluation and favorable recommendation of the immediate foreman are a ready mechanism for discrimination against Blacks much of which can be covertly concealed ... ."226 Consequently, judges refused to accept the lack of interest argúment from employers who left hiring and promotion decisions in the hands of white supervisors without specifying standards to guide their discretion.

[The employer's] contention that the reason black employees were not promoted to supervisory positions was because they did not "ask" to be promoted is without merit. ... [A] black employee with knowledge of the nominal number of black foremen, the Company's past discriminatory policies, and the current practice of promotion via the recommendation of an incumbent foreman could hardly be expected to make a meaningless request indicating his willingness to be promoted. ${ }^{228}$

In the more recent period, courts have retreated from this approach. Although plaintiffs still prevail more often against employers who use subjective selection systems, the strong judicial condemnation of subjective employment processes is missing from most opinions. Rather, judges now emphasize that the "use of sub-

${ }^{223}$ In Lee $v$ Washington County Bd. of Education, 625 F2d 1235 (5th Cir 1980), for example, a school board attempted to excuse its failure to hire Black coaches by arguing that few Blacks had applied for coaching positions. The evidence showed that the Board had not advertised its coaching positions, but had instead relied on word-of-mouth recruiting. In a departure from its long-established approach, the Fifth Circuit affirmed the district court's finding that the school board's reliance on word-of-mouth recruiting had not "actually discriminated against blacks" by excluding them from the network of job information. Id at 1238.

${ }^{224}$ See, for example, Eubanks, 635 F2d 1341 (characterizing the promotion of a white man made on the basis of nepotism as a decision that was unrelated to race); Sheet Metal Workers, Local 122, 463 F Supp at 422 (finding that any discriminatory impact of nepotism was negated by the union's use of an affirmative action program).

${ }^{225}$ Rowe v General Motors Corp., 457 F2d 348, 359 (5th Cir 1972).

${ }^{228}$ United States v N. L. Industries, Inc., 479 F2d 354, 369 (8th Cir 1973). 
jective criteria ... does not in itself . . supply an inference of discrimination." 227 Absent concrete proof that "minority employees were directed away from higher-paying [job] classifications," judges have become more inclined to view job segregation as a reflection of minorities' own job preferences, even in cases in which assignment and progress depends on the unguided discretion of white superiors. ${ }^{228}$ Because employers use subjective processes more often in connection with white-collar work than blue-collar work, ${ }^{229}$ this shift may have been particularly harmful to minorities seeking higher-level white-collar jobs. Over time, as the courts have become less skeptical of subjective selection processes, they have also reacted less favorably to minorities' efforts to challenge racial segregation in white-collar employment. ${ }^{230}$

Just as the courts have evaluated the evidence in a manner that is less favorable to plaintiffs, they have also applied the disparate treatment framework in a manner that is less favorable to plaintiffs in the more recent period. The preceding Section noted that the courts have restricted plaintiffs' use of the disparate impact framework since the late 1970s. Further analyses reveal that in addition to forcing plaintiffs into a disparate treatment model more frequently, the courts have also toughened their approach to disparate treatment cases over time. In contrast to disparate impact cases, in which plaintiffs' success rates remained stable across the periods, in disparate treatment cases, plaintiffs' success rates plummeted. In the 1967-77 period, courts rejected the lack of interest argument in 100 percent of the disparate treatment claims;

${ }^{227}$ Eubanks, 635 F2d at 1347. See also Page v U.S. Industries, Inc., 34 FEP (BNA) 430, 435 (5th Cir 1984) (containing a similar statement).

${ }^{228}$ Page, 34 FEP at 437.

${ }^{220}$ See, for example, Bartholet, 95 Harv L Rev at $973 \mathrm{n} 86$ (cited in note 120) (collecting sources). In our data set, $80 \%$ (8 out of 10 ) of the race discrimination cases in which plaintiffs sought access to white-collar work involved subjective selection systems. By contrast, $64.2 \%$ (34 out of 53) of the race discrimination cases in which plaintiffs sought access to blue-collar work involved subjective selection systems. This difference is not statistically significant, however ( $p$-value $=.33$ ).

${ }^{230}$ As Table 8 shows, in the early period, the type of employment plaintiffs sought made little difference to the outcome of the lack of interest argument. In fact, plaintiffs fared slightly better in white-collar cases than in blue-collar cases. In the more recent period, however, the pattern reversed. Although plaintiffs won over half of the blue-collar cases, they did not win any of the white-collar cases.

These results suggest that the negative effect for white-collar work that emerged from our earlier logit analysis is attributable to, or at least more pronounced in, the early period. If so, then contrary to the implications of the weaker evidence explanation, the increased proportion of white-collar cases in the modern period did not "weaken" the modern cases, but in fact, would have strengthened them slightly if the courts had continued to respond to them in the same favorable manner as they had in the early period. 
in the 1978-89 period, they did so in only 26.7 percent of such claims. ${ }^{231}$

This change parallels the other, larger shifts in judicial attitude and approach. The courts' skepticism toward statistical evidence has led them to impose a more stringent standard of proof in disparate treatment cases. Early courts presumed that if minorities had always had the same work opportunities as whites, they would not have chosen their own economic disenfranchisement. ${ }^{232}$ Over time, however, judges have become less willing to attribute racial disparities in employment to discrimination. In order to find for plaintiffs under a disparate treatment model, the courts now insist on proof that the employer took specific actions to cause the disparities at issue. "If the plaintiffs' statistics fail to establish a causal link between [some specifically] challenged practice and discrimination, courts can infer discrimination only when the 'inexorable zero' or gross statistical disparities . . . compel this inference." "233 Because it is frequently impossible to trace broad patterns of segregation to particular employment practices, few plaintiffs could meet this heightened standard of proof even if courts still evaluated non-statistical evidence as favorably as they had in the earlier era. Given that judges respond less favorably to evidence that the employer relied on word-of-mouth recruiting or subjective criteria, plaintiffs now face an almost impossible burden of establishing classwide disparate treatment.

Ironically, the courts' success in dismantling racial segregation in the early era of Title VII enforcement may have contributed to the less favorable treatment of race discrimination plaintiffs in the modern era-but not because all forms of employment discrimination were legally destroyed. As legal pressure induced some employers to lower racial barriers, many African Americans and other

${ }^{231}$ Table 8 shows that in the early period plaintiffs fared as well (in fact, slightly better) under a disparate treatment framework as they did under a disparate impact framework; they won $100 \%$ (5 out of 5) of the disparate treatment cases, and $84.2 \%$ (32 out of 38) of the disparate impact cases. In the modern period, however, although plaintiffs continued to win $80.0 \%$ ( 4 out of 5 ) of the disparate impact cases, their success rate dropped to only $26.7 \%$ ( 4 out of 15 ) in disparate treatment cases. These results suggest that the negative effect for disparate treatment that emerged from our earlier logit analysis is attributable to the 1978-89 period. Although it is also possible that the decline in plaintiffs' success in disparate treatment cases reflects the fact that the modern disparate treatment cases were weaker than the early disparate treatment cases, it is doubtful that the modern disparate treatment cases were weaker to a degree sufficient to explain a decline of this magnitude.

${ }^{232}$ See, for example, League of United Latin American Citizens v City of Santa Ana, 410 F Supp 873, 892 (C D Cal 1976) (stating that "Title VII . . . assumes that protected groups are both qualified for and interested in employment").

${ }^{233}$ Carroll $v$ Sears, Roebuck \& Co., 708 F2d 183, 195 (5th Cir 1983). 
minorities took advantage of opportunities that had never before been available to them. These signs of progress have led many whites to believe that employers no longer discriminate. ${ }^{234}$ In this view, continuing patterns of racial segregation must reflect racial differences that arose from influences outside the labor market. The lack of interest argument targets racial differences in culture and upbringing to attribute remaining job disparities to minorities' lack of initiative in pursuing higher-paying employment. ${ }^{235}$

Like many others, federal judges have become more inclined to accept this rationalization. From a legal environment in which the courts proclaimed that "Title VII [] assumes ... that protected groups are ... interested in [higher-paying] employment," ${ }^{236}$ we have entered an era in which many judges espouse such racially stereotyped assertions as "blacks prefer housekeeping jobs." ${ }^{237}$

\section{The role of the courts of appeals.}

The courts of appeals have played an important role in bringing about this shift in judicial attitudes, as Table 9 shows. Panel A presents plaintiffs' success rates in district court cases that were not appealed (column 2), in district court cases that were appealed (column 3), and in the resulting group of appellate cases (column 4). Panel B shows the percentage of courts of appeals decisions that reversed district court judgments for plaintiffs (column 2), for employers (column 3), and for both parties combined (column 4), in race discrimination cases.

\footnotetext{
${ }^{284}$ See, for example, Kluegel, 28 Am Behav Scientist at 764-65 (cited in note 24) (reporting that in 1976, $71.2 \%$ of whites believed that Blacks "no longer face[d] unfair employment conditions," and "in fact ... are favored in many training and job programs"); Kluegel and Smith, 47 Am Soc Rev at 519 (cited in note 43) (reporting that in 1980, 73\% of whites saw "blacks" opportunity as equal to or greater than the average person in America (assuming that persons work hard)").

${ }^{238}$ See Croker v Boeing Co., 662 F2d 975, 992-93 (3d Cir 1981) (disregarding evidence that the company "directed applicants to indicate certain job choices" to affirm the district court's finding that preference explained African Americans' placement in lower-paying jobs); Hilton $v$ Wyman-Gordon Co., 624 F2d 379, 380 (1st Cir 1980) (affirming the district court's finding that "blacks preferred housekeeping jobs" to jobs in higher-paying departments); Lewis v Tobacco Workers' Int'l Union, 577 F2d 1135, 1143 (4th Cir 1978) (implicitly finding that African Americans preferred lower-paying, seasonal jobs in the stemmery).

238 League of United Latin American Citizens, 410 F Supp at 892.

${ }^{237}$ Hilton, $624 \mathrm{~F} 2 \mathrm{~d}$ at 380.
} 
TABle 9: Plaintiffs' Success Rates in District Court and Court of Appeals

Cases, and Reversal Rates in Court of Appeals, for Early and Modern Race Discrimination Cases

\begin{tabular}{|c|c|c|c|c|}
\hline \multirow[b]{2}{*}{$1967-77$} & $\begin{array}{l}\text { District Court } \\
\text { Cases } \\
\text { (Not Appealed) }\end{array}$ & \multicolumn{2}{|c|}{$\begin{array}{c}\text { District Court } \\
\text { Cases } \\
\text { (Appealed) }\end{array}$} & $\begin{array}{l}\text { Court of } \\
\text { Appeals } \\
\text { Cases }\end{array}$ \\
\hline & $82.6 \% \quad(19 / 23)$ & $30.0 \%$ & $(6 / 20)$ & $90.0 \% \quad(18 / 20)$ \\
\hline $1978-89$ & $50.0 \%$ & $16.7 \%$ & $(2 / 12)$ & $33.3 \% \quad(4 / 12)$ \\
\hline \multicolumn{5}{|c|}{$\begin{array}{l}\text { B. Reversal Rates in Courts of Appeals, } \\
\text { by Party Who Won in District Court }\end{array}$} \\
\hline & P Won Below & \multicolumn{2}{|c|}{ D Won Below } & Total \\
\hline $1967-77$ & $33.3 \%$ & $100.0 \%$ & $(14 / 14)$ & $80.0 \% \quad(16 / 20)$ \\
\hline $1978-89$ & $100.0 \%$ & $40.0 \%$ & $(4 / 10)$ & $50.0 \%$ \\
\hline
\end{tabular}

In the 1967-77 period, the appellate courts were critical to race discrimination plaintiffs' near-universal success. Although plaintiffs prevailed on the lack of interest argument in 82.6 percent of the district court cases that were not appealed, they did so in only 30 percent of the district court cases that were appealed. The courts of appeals ruled for plaintiffs in an overwhelming 90 percent of the appealed cases. They accomplished this by reversing district court rulings for employers at disproportionate-and phenomenal-rates. Whereas the courts of appeals reversed rulings in favor of plaintiffs in only 33.3 percent of the cases, they reversed rulings in favor of employers in 100 percent of the cases that came before them. Thus, appellate judges acted as strong allies in minority plaintiffs' efforts to dismantle job segregation; they ensured that trial judges did not excuse segregation as the expression of minorities' own lack of interest in more remunerative work.

In the 1978-89 period, however, the pattern changed markedly. Race discrimination plaintiffs fared worse in the district courts than they had in the earlier era. When they sought help from the courts of appeals, assistance was far less forthcoming: plaintiffs' success rate on appeal fell from 90 percent in the earlier period to only 33.3 percent in the later period. Contrary to their previous approach, the courts of appeals were more likely to reverse rulings in favor of plaintiffs than rulings in favor of employers. In fact, the 
reversal rates are almost the mirror image of what they had been in the earlier era; they reversed rulings in favor of plaintiffs in 100 percent of the cases, while reversing rulings in favor of employers in only 40 percent of the cases. Although the numbers of cases are small, these results suggest that appellate judges have retreated from their earlier pro-civil rights approach. In the more recent era, they have allied themselves with employers rather than plaintiffs.

The data also show that the decline in race discrimination plaintiffs' success rate is not a function of an increase in plaintiffs' rate of appeal. As noted earlier, a number of studies have reported that appellate courts tend to affirm trial court decisions. ${ }^{288}$ Theoretically, because our data set includes appellate cases, the decline in plaintiffs' overall success rate could have resulted from an increase in the rate at which plaintiffs began to appeal adverse rulings. ${ }^{239}$ Table 9 indicates, however, that this explanation cannot account for the decline. Plaintiffs' success rates declined considerably in district court cases as well as courts of appeals cases. Furthermore, plaintiffs' success rate fell by similar proportions in cases appealed by plaintiffs and by employers. That courts of appeals became more likely to accept the lack of interest defense in the modern era, regardless of which party appealed, suggests that appellate judges may have been actively attempting to reverse the earlier, pro-plaintiff direction of the law. ${ }^{240}$

\section{Summary and implications.}

Our findings suggest that in the late 1970s, the courts adopted an approach to the lack of interest argument that is less favorable to race discrimination plaintiffs. Our variable means and decomposition analyses reveal that the more recent cases are not sufficiently weaker (or otherwise different) than the earlier cases to ac-

\footnotetext{
${ }^{238}$ See note 165 and accompanying text.

${ }^{238}$ See Henderson and Eisenberg, 37 UCLA L Rev at $504 \mathrm{n} 115$ (cited in note 180); Eisenberg and Schwab, $56 \mathrm{U}$ Chi L Rev at 517 (cited in note 165).

${ }^{240}$ Because courts of appeals may be more likely to publish reversals than affirmances, the published decisions in our data set may overstate the actual number of cases in which courts of appeals reversed on the lack of interest argument. Nonetheless, because this effect should be uniform across cases in which plaintiffs won below and cases in which employers lost below, it cannot explain the increased rate at which courts of appeals began to reverse judgments in favor of plaintiffs and to affirm judgments in favor of employers in the modern period. On the other hand, if the courts of appeals were attempting to change the law in a direction less favorable to plaintiffs, they may have published a higher proportion of decisions reversing judgments in favor of plaintiffs and affirming judgments in favor of employers in the modern period. See Eisenberg and Schwab, $56 \mathrm{U}$ Chi L Rev at 535-38 (cited in note 165).
} 
count for the dramatic decline in plaintiffs' success. Because our analyses do not control directly for the persuasive quality of the evidence beyond a certain threshold, one might argue that an unobserved deterioration in the quality of the evidence accounts for the unexplained portion of the decline in plaintiffs' success rate. For a number of reasons, however, this possibility is unlikely.

In the 1978-89 period, the courts became substantially more likely to accept the lack of interest defense even in cases that provided a strong evidentiary basis for rejecting this argument in the 1967-77 era. In fact, since 1978 the courts have responded in a manner less favorable to plaintiffs to all three types of evidence that they considered compelling proof in the earlier era (evidence of past discrimination, formal recruiting, and subjective selection systems). To accept the weaker evidence explanation, one would have to argue that the courts' responses to these three types of evidence changed because the quality of the evidence within each category became so much poorer that it merited less weight even under the same standards of evaluation. For some types of evidence, such as evidence that the employer relied on a subjective selection system, our coding strategy makes this argument unconvincing. We treated a case as one involving a subjective selection system, for example, only if the court's opinion included an affirmative acknowledgement that the employer's system satisfied a standardized definition of a subjective system that we applied uniformly across all cases. Given that our definition of a subjective system did not change over time, it is difficult to see how the earlier cases could have involved evidence of subjectivity that was sufficiently more powerful than that present in the more recent cases to explain the sizeable decline in the effect of this factor on case outcomes. Rather, the shift suggests that judges now regard a subjective selection process as a less powerful indicator of discrimination. ${ }^{241}$

Even if one assumes a deterioration in the quality of the evidence, this still does not account for our results for some of the non-evidentiary factors. Over time, the courts have begun to respond to white-collar and blue-collar cases, and to disparate treatment and disparate impact cases, in opposite ways; the courts of appeals have become more likely to reverse rulings in favor of

242 Compare, for example, United States v N. L. Industries, Inc., 479 F2d 354, 368 (8th Cir 1973); and Rowe $v$ General Motors Corp., 457 F2d 348, 359 (5th Cir 1972); with Eubanks v Pickens-Bond Constr. Co., 635 F2d 1341, 1347 (8th Cir 1980); and Page v U.S. Industries, 34 FEP (BNA) 430, 434 (5th Cir 1984). 
plaintiffs than rulings in favor of employers. It is unlikely that the relative quality of the proof in these sets of cases changed sufficiently to account for such dramatic reversals. Judicial bias explains the results more consistently and plausibly.

The language of the opinions supports the judicial bias explanation, not the weaker evidence explanation. In the more recent opinions, judges did not emphasize that the plaintiffs' evidence was weak. Instead, they expressed skepticism about the extent to which evidence of past discrimination, subjective selection systems, and word-of-mouth recruiting suffice to refute the lack of interest explanation. Taken together with their declarations of lack of faith in statistical proof, the courts' rhetoric signals an increase in judges' underlying willingness to attribute job segregation to forces other than discrimination-rather than a decrease in the quality of plaintiffs' proof.

Finally, data from the ABF sample also undercut the selection effects explanation. This theory hypothesizes that plaintiffs' success rates declined not because the courts adopted less favorable legal standards, but because an increase in employers' relative stakes or abilities to predict case outcomes led them to offer more to settle the cases, especially cases that were strong for plaintiffs. If this theory were accurate, a greater proportion of the cases filed after 1977 should have settled before trial. Yet, in the ABF sample, race discrimination cases were slightly less likely to settle-and more likely to be resolved against plaintiffs on pre-trial motion-than they had been in the earlier period. Thus, even after accounting for settlement and other pre-trial dispositions, race discrimination plaintiffs have fared worse in the modern era.

Based on these findings, we conclude that the decline in plaintiffs' success rates reflects in part a shift toward less pro-plaintiff standards for evaluating the validity of the lack of interest defense in race discrimination cases. Just as the courts' culturally-laden assumptions about women's work aspirations led judges to impose more difficult standards for refuting the lack of interest argument in sex discrimination cases than in race discrimination cases in the 1967-89 period as a whole, so too the courts' changed perceptions of racial discrimination have led judges to impose higher standards on race discrimination plaintiffs since the late 1970s. The shift has been more subtle in race discrimination cases. Judges have continued to consider the same types of evidence but have simply given it less weight.

Because the shift away from a pro-plaintiff approach in race discrimination cases was not accomplished through the announce- 
ment of a new "bright-line" rule but instead through a "low-profile" change in judges' evaluation of the sufficiency of the evidence, ${ }^{242}$ attorneys may have been slow to realize that the shift was occurring. Prior to the Supreme Court's 1977 decisions in Teamsters, Dothard, and Hazelwood, the courts of appeals in effect (if not explicitly) rejected the lack of interest argument as a matter of law; they reversed all of the cases in which the trial courts had accepted this argument. By defining the lack of interest issue as a question of fact to be delegated to the trial courts, ${ }^{243}$ the Court's 1977 decisions created an opportunity for employers to litigate this issue on a case-by-case basis. ${ }^{244}$ Yet, the earlier judicial approach was sufficiently well-established and favorable to plaintiffs that even seasoned attorneys may not have predicted that under a more open-ended factual inquiry, the lower courts would widely accept minorities' lack of interest as an adequate justification for racial segregation on the job.

If attorneys were slow to detect the change, this could help account for plaintiffs' lower success rates after 1977 . That the more recent race discrimination cases addressing the lack of interest argument were no stronger (and, if anything, were somewhat weaker) than their earlier counterparts may indicate that plaintiffs' attorneys continued to pursue claims that were considered reasonably strong under the old, more lenient standards, but not under the new ones. ${ }^{245}$ If so, race discrimination plaintiffs would have suf-

${ }^{242}$ For a discussion of the distinction between bright-line and low-profile legal changes within the context of product liability cases, see Henderson and Eisenberg, 37 UCLA L Rev at 509-10 (cited in note 180).

243 See Schultz, 103 Harv L Rev at 1759-66 (cited in note 20).

${ }^{244}$ Hazelwood provided the clearest signal of this opportunity. The Court reversed the Eighth Circuit's judgment for the plaintiff and remanded the case to the trial court for a more in-depth factual analysis of Blacks' level of interest in the work at issue. Hazelwood School District $v$ United States, 433 US 299, 309, 310-13 (1977). For a discussion of this aspect of the Hazelwood decision, see Schultz, 103 Harv L Rev at 1763-65 (cited in note 20).

${ }^{245}$ Even if, as we have suggested, the legal standard changed to become less favorable to plaintiffs, selection models predict that the parties will adjust to the new standard over time. Assuming that plaintiffs' and defendants' attorneys have equal information about the change in standards, and assuming that the parties' relative stakes and abilities to assess their cases accurately remain unaltered, plaintiffs should eventually stop pursuing the claims that are no longer considered meritorious under the new standard. As a result, case filings should decline, and the subset of cases litigated under the new, more burdensome standard should be stronger than the cases litigated under the old standard. See Priest, $3 \mathrm{~J}$ of $L$ Econ \& Org at 199-200 (cited in note 91). Particularly if the nature of the change was a "low-profile" change, however, we should "find some significant period during which plaintiffs would fail to detect the true magnitude of the change, bring the same old set of claims (let alone an increasingly ambitious set, based on prior trends), and suffer unprecedented losses." Henderson and Eisenberg, 37 UCLA L Rev at 517 n 154 (cited in note 180). 
fered unprecedented losses. In our data set, plaintiffs' success rates on the lack of interest issue fell dramatically and steadily between 1978 and 1983. Thereafter, both the number of filed cases in which the lack of interest argument was a potential defense and the number of published cases litigating this defense dropped off to almost zero. Eventually, plaintiffs' attorneys may have realized that the legal system was less hospitable to challenges to racial segregation, and stopped pursuing claims that unfavorable legal developments had doomed to failure.

IV. The Politics of the Lack of Interest Defense: the Relationship Between Judges' Decisions and Their Political Affiliations

Both our quantitative analyses of the cases and our more qualitative readings of the judicial opinions suggest that the disparities in plaintiff's' success rates on the lack of interest defense reflect differences in the attitudes and approaches courts have brought to their interpretation of cases of similar merit. To explore the causes of the disparities in success rates more fully, this Section examines the relationship between judges' political affiliations and their rulings on the lack of interest defense. There is little disagreement that judges' political, social, and personal values may affect their decisions. Although a wide range of factors may exert an influence, political scientists regard the president who appointed the judge as an important indicator of the larger values that may influence a judge's decisions. As one prominent pair of scholars explained:

$[P]$ residents consider the political values and attitudes of potential judges because they have realized intuitively what American judicial scholars have taught for almost a century: the business of judging is not merely a mechanical process of "following the law" and "being guided by past precedents"; there is considerable discretion involved in judicial decisionmaking; the political values and orientations of the judges do affect the way they resolve judicial issues, especially when precedents are conflicting or when the court is being asked to tread in new and uncharted realms. ${ }^{246}$

For analogous reasons, many researchers conceptualize political party affiliation as a measure of the larger values that affect judges'

${ }^{246}$ Robert A. Carp and C. K. Rowland, Policymaking and Politics in the Federal District Courts 52 (Tennessee, 1983). 
voting behavior. "Party affiliation ... [is] regarded as a crude, but still ... effective, background indicator of judges' values because it indicates a collection of like minded persons (especially among political activists), is an important socializing institution, and is an important reference group for people active in public affairs."247

Despite a consensus that judges' political leanings may influence their decisions, scholars disagree about whether this influence can be discerned in the outcomes of litigated cases. An extensive political science literature is premised on the assumption that partisan influences can be detected and measured through the parties' success rates or judges' voting records in litigated cases. There is substantial support for this view. A number of studies of appellate courts have found that Democratic judges and judges appointed by Democratic presidents tend to have more liberal voting records-voting more frequently for labor unions or civil rights claimants, for example-than Republican judges and judges appointed by Republican presidents. ${ }^{248}$ Although earlier work did not find similar relationships at the trial court level, more recent and comprehensive research reports that among federal district judges, Democrats vote more liberally than Republicans. This research also finds that the appointing president is an important predictor of judges' decisions, particularly in civil rights and civil liberties cases. ${ }^{24}$ According to many political scientists, differences in judicial voting patterns by political affiliation vary with the ideological content of the cases and the degree of discretion permitted judges. Judges' partisan values emerge more powerfully in eras and areas

${ }^{247}$ Malcolm M. Feeley, Another Look at the 'Party Variable' in Judicial Decision Making: An Analysis of the Michigan Supreme Court, 4 Polity 91, 93 (1971). As Carp and Rowland have cautioned, however, there is no simple causal relationship between party affiliation and subsequent voting patterns. "[T]he homogeneity of the bench ensures that even judges from different parties will bring more similar than different attributes to their task." Carp and Rowland, Policy Making and Politics at 30 (cited in note 246). In addition, party affiliation is not always a good indicator of a judge's political and social values, because people frequently choose their party affiliations for reasons other than value conformity. Id. Finally, "the very nonideological, nonprogrammatic nature of American political parties in general tends to restrain the party factor from becoming a potent indicator of liberal-conservative policy propensity." See id at 31 .

${ }^{248}$ See, for example, Jon Gottschall, Reagan's Appointments to the U.S. Courts of Appeals: The Continuation of a Judicial Revolution, 70 Judicature 48, 54 (1986); Donald R. Songer and Sue Davis, The Impact of Party and Region on Voting Decisions in The United States Courts of Appeal, 1955-1986, 43 W Pol Q 317, 323 (1990). For summaries of such research, see Carp and Rowland, Policymaking and Politics at 25-32 (cited in note 246); Schwab and Eisenberg, Influence of Judicial Background at 2-3 (cited in note 78).

${ }^{249}$ See Carp and Rowland, Policymaking and Politics at 32-36, 64-73 (cited in note 246). 
of law in which controlling Supreme Court precedent leaves individual judges more room to maneuver. ${ }^{250}$

In contrast to the political science literature, the literature on litigation selection effects suggests that even if judges' political values influence their decisions, this influence will not be reflected in the outcomes of litigated cases. Because the parties will adjust their assessments of their likelihood of prevailing and their settlement strategies to account for judges' attitudes, plaintiffs' success rates will be similar even across cases tried by courts or judges with different political perspectives. Priest and Klein state:

It is widely believed that the decisions of a single judge will reflect that judges' individual attitudes .... The selection hypothesis, on the other hand, presumes that the parties in settlement negotiations will anticipate the predilections of a judge, just as they would anticipate the application of a legal rule or the collective attitudes of a jury. Thus, the rate of success in contested civil bench trials similarly ought to tend toward equality among judges $\ldots . .^{251}$

Priest and Klein treat the selection hypothesis as empirically verifiable. To support it, they cite evidence that in contract and negligence cases decided between 1960 and 1980 and published in LEXIS, plaintiffs experienced substantially similar success rates before five different United States district court judges. ${ }^{252}$ The authors concluded that although they had "little doubt that the attitudes of some of the judges ... differ in some degree . ..., no evidence of a difference in the attitudes of these judges [is] discernible from trial outcomes because of the selection effect."

The political science and selection effects literature thus yield differing predictions about whether the outcomes of the cases in our data set will vary according to judges' political affiliations. The political science literature suggests that judges' rulings on the lack of interest argument may vary substantially depending on their political leanings. In particular, partisan differences should emerge in cases and time periods for which there is little ideological consensus and/or little controlling legal precedent on the lack of interest issue. On the other hand, the selection effects literature predicts that no partisan differences in judges' voting records will emerge in

$2 s 0$ See id at 10-11.

${ }_{251}$ Priest and Klein, $13 \mathrm{~J}$ Legal Stud at 34-35 (cited in note 53).

262 See id at 35-36.

253 Id at 36. 
any areas. Consequently, any findings of substantial differences in judges' rulings on the lack of interest argument according to their political affiliation would undermine the selection effects hypothesis.

To investigate these issues, we examine the relationship between judges' political affiliations and their decisions on the lack of interest issue in (1) the race and sex discrimination cases in the 1967-89 period, and (2) the race discrimination cases in the 196778 and 1978-89 periods. For both pairings of cases, we present three sets of analyses. The first set of analyses (Tables 10A and 11A) shows the percentage of judges appointed by each president (or group of presidents), and the percentage of judges appointed by Democratic and Republican presidents, who ruled or voted to rule in favor of plaintiffs on the lack of interest argument. The second set of analyses (Tables 10B and 11B) shows the percentage of judges identified as Democrats, Republicans and independents who ruled or voted to rule in favor of plaintiffs on the lack of interest argument. ${ }^{254}$ In both these sets of analyses, the unit of focus is the decision of the individual judge rather than the decision of the court. ${ }^{255}$ By contrast, Tables $10 \mathrm{C}$ and $11 \mathrm{C}$ show the percentage of cases in which the courts resolved the lack of interest in favor of plaintiffs, according to whether the district judge or a majority of the appellate judges were appointed by Democratic or Republican presidents. None of these analyses controls for the relative strength or weakness of the cases decided by judges of differing political affiliations. To the extent that the absence of such controls introduces any bias into the analyses, it would bias them

284 For these analyses, we consulted several standard biographic sources to determine the political party affiliation of each judge. From these sources, we were unable to identify the party affiliation of $11.1 \%$ (17 out of 153) of the judges involved in the race discrimination cases, and $12.0 \%$ (11 out of 92 ) of the judges involved in the sex discrimination cases. Interestingly, in both race and sex discrimination cases, the percentage of judges for whom we were unable to determine party affliation increased over time. In race discrimination cases, this percentage rose from $8.7 \%$ (9 out of 104) of all judges in the 1967-77 period to $16.3 \%$ ( 8 out of 49 ) of all judges in the $1978-89$ period. In sex discrimination cases, there were no unidentified judges for the early period.

${ }_{255}$ Because district courts consist of single judges, the unit of analysis makes no difference to the analysis of district court decisions. Appellate courts consist of panels of at least three judges, however, and these first two sets of analyses reflect how each individual appellate judge voted to resolve the lack of interest issue rather than how the majority of the panel resolved the issue. For purposes of these analyses, appellate judges are treated as having voted for plaintiffs if they joined in a majority opinion which rejected the lack of interest argument or dissented from a majority opinion which accepted this argument. 
against finding any relationship between judges' voting records and their political affiliations. ${ }^{286}$

TABle 10: Percentage of Judicial Decisions in Favor of Plaintiffs in Sex and Race Discrimination Cases, By Judges' Political Affiliations

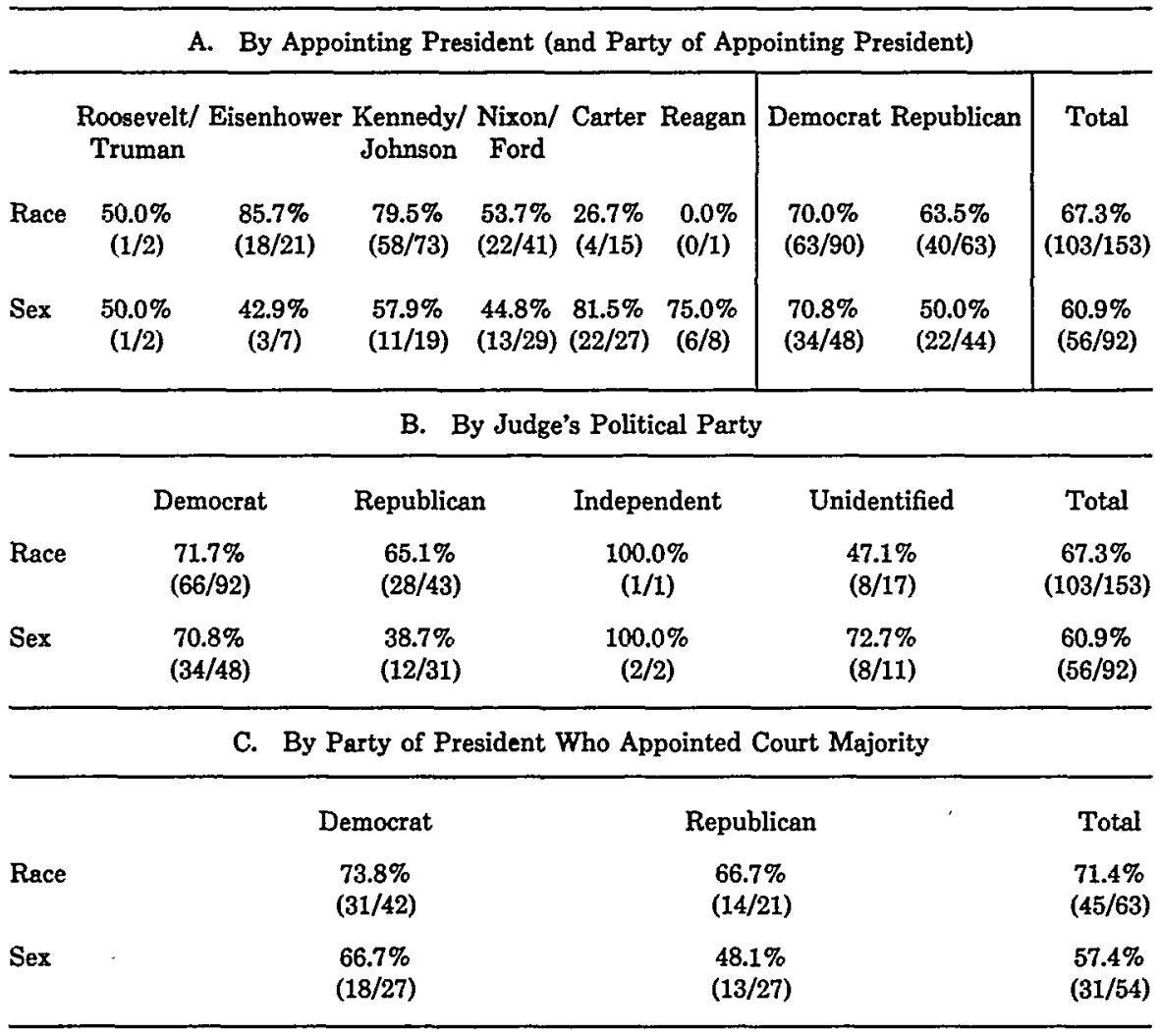

Table 10 provides little support for the selection effects hypothesis. Contrary to its predictions, judges' decisions on the lack

2ss According to the selection effects literature, the parties adjust their settlement strategies to account for any judicial partisanship. If, for example, Democratic judges are more predisposed to favor plaintiffs than Republican judges, defendants should offer more to settle cases to be heard by Democratic judges, particularly cases that are relatively strong for plaintiffs. Because Republican judges will hear cases that are stronger for plaintiffs than those heard by Democratic judges, both groups of judges will rule in favor of plaintiffs with approximately the same frequency. As a result of this selection process, no differences in Democratic and Republican judges' voting records would be evident unless one controlled for the relative strength of the cases heard by the two groups of judges. Thus, if anything, our failure to control for the relative strength of the cases biases our analyses against finding the differences in Democratic and Republican judges' votes that would emerge if such controls were present. 
of interest issue vary substantially depending on their political affiliations, particularly in some areas. In sex discrimination cases, as Panel A shows, judges appointed by different presidents had markedly different voting records. The percentage of judges voting for plaintiffs ranged from a high of 81.5 percent for judges appointed by Carter to a low of 42.9 percent for judges appointed by Eisenhower. Overall, judges appointed by Democratic presidents were significantly more likely to vote for plaintiffs than those appointed by Republicans. Panel B also discloses significant differences between Democratic and Republican judges' records in sex discrimination cases, and Panel $\mathrm{C}$ reveals similar (though less substantial) differences in the outcomes of sex discrimination cases decided by courts controlled by Democratic appointees and Republican appointees. ${ }^{257}$ Although in race discrimination cases, no significant party differences emerge, there are substantial differences in the voting records of judges appointed by different presidents. The proportion of judges who voted for race discrimination plaintiffs ranged from a high of 85.7 percent for Eisenhower-appointed judges to a low of 26.7 percent for Carter-appointed judges.

The analyses in Table 10 also suggest that plaintiffs' lower overall success rate in sex discrimination cases is attributable to the decisions of Republican judges, appointees and courts, rather than to their Democratic counterparts. As Panel A shows, judges appointed by.Democratic presidents were equally likely to vote for plaintiffs in sex and race discrimination cases (approximately 70 percent). By contrast, however, judges appointed by Republican presidents were far more likely to vote for plaintiffs in race discrimination cases than in sex discrimination cases: Republican appointees voted for plaintiffs in 63.5 percent of all race discrimination cases, but they did so in only 50 percent of all sex discrimination cases. Panel B reveals similar trends among Democratic and Republican judges. In fact, because Republican judges were even less likely than judges appointed by Republican presidents to vote for plaintiffs in sex discrimination cases, the difference in judges' voting records in sex and race discrimination cases is more pronounced among Republican judges than among judges

${ }^{287}$ For Panel A, the difference in Democratic and Republican appointees' voting records reported in sex discrimination cases is significant at .04. Similarly, for Panel B, the difference in Democratic and Republican judges' records in sex discrimination cases is significant at .005 . For Panel C, however, the difference in plaintiffs' success rates in cases decided by Democratically-controlled courts and Republican-controlled courts is not statistically significant $(p$-value $=.17)$. 
appointed by Republican presidents. Similar, though slightly smaller, differences emerge among Republican-controlled courts in Panel C.258

In sex discrimination cases addressing the lack of interest argument, judges' voting patterns parallel remarkably closely the larger trends in judges' voting behavior reported in the political science literature. The liberal judicial position rejects the lack of interest argument; the conservative judicial position accepts this rationalization. ${ }^{259}$ Thus, our finding of a stronger pro-plaintiff record on the part of judges with Democratic affiliations is consistent with the finding of greater Democratic liberalism reported in other studies. $^{280}$

238 Among these three analyses, only the difference in Republican judges' voting records in race and sex discrimination cases (shown in Panel B) is statistically significant at .10 or less; the p-value is .04 . The p-value for the difference in Republican appointees' records in race and sex discrimination cases (Panel $A$ ) is .16, and the p-value for the difference in Republican-controlled courts' records in race and sex discrimination cases (Panel C) is .20.

The greater disparity in the voting records of Republican judges (Panel B), compared to the voting records of Republican appointees or Republican-controlled courts (Panels A and C), is attributable mainly to the combined effects of (1) the fact that Republican presidents were more likely to appoint Democratic judges than were Democratic presidents to appoint Republican judges; and (2) the fact that Democratic judges appointed by Republican presidents ruled in favor of sex discrimination plaintiffs more frequently than Republican judges appointed by Republican presidents. Specifically, in our data set, Republican presidents appointed 19 Democratic judges and 73 Republican judges, but Democratic presidents appointed only one Republican judge as opposed to 121 Democratic judges.

The voting records of the various groups of judges in sex and race discrimination cases were as follows:

$\begin{array}{rcc} & \text { Sex } & \text { Race } \\ \text { Democratic Appointee } & & \\ \text { Democratic Judge } & 73.2 \% & 72.5 \% \\ \text { Republican Judge } & 0.0 \% & - \\ \text { Republican Appointee } & & \\ \text { Democratic Judge } & 57.1 \% & 66.7 \% \\ \text { Republican Judge } & 40.0 \% & 65.1 \%\end{array}$

Thus, consistent with trends reported by Carp and Rowland in their study of all federal district court decisions, see Carp and Rowland, Policymaking and Politics at 79 (cited in note 246), in the sex discrimination cases in our data set, Democratic judges appointed by Republican presidents voted in favor of plaintiffs more frequently than Republican judges appointed by Republicans (but less frequently than Democratic judges appointed by Democrats). The figures in Panel B of Table 10 reflect the sharper differences in the voting records of Republican-appointed, Republican-affiliated judges.

${ }^{259}$ For a description of the rhetoric and assumptions underlying the liberal and conservative judicial positions, see Schultz, 103 Harv L Rev at 1800-14 (cited in note 20).

${ }^{200}$ In their study of over 27,000 federal trial court decisions issued between 1933 and 1977, for example, Carp and Rowland found that the liberal-conservative voting disparity between Democrats and Republicans "widen[ed] into a sizable chasm" beginning in 1969, around the period when our data set begins. See Carp and Rowland, Policymaking and Politics at 14-23, 36 (cited in note 246). 
In addition, although the number of sex discrimination cases decided by some of the presidential appointees in our data set is small, the trends that emerge are consistent with those reported in other studies. Panel A shows that Kennedy and Johnson appointees voted for plaintiffs more frequently than Eisenhower appointees, and Nixon and Ford appointees voted for plaintiffs less frequently than Kennedy and Johnson appointees. Similarly, in Carp and Rowland's study, Kennedy and Johnson appointees voted more liberally than Eisenhower appointees, and Nixon and Ford appointees voted more conservatively than Kennedy and Johnson appointees in both the entire sample of cases and in the subset of civil rights and civil liberties cases. ${ }^{261}$ As Carp and Rowland emphasize, these results "are all in the expected direction and they conform to the body of intuitive, anecdotal, and historical information about these ... presidents and the judges each appointed."262 Even if Carter and Reagan appointees are excluded from our data set, judges appointed by Democratic presidents (Roosevelt, Truman, Kennedy, and Johnson) were more likely to rule for sex discrimination plaintiffs than judges appointed by Republican presidents (Eisenhower, Nixon, and Ford). ${ }^{263}$

The largest advance for women on the lack of interest issue came with the Carter appointees. Whereas Nixon and Ford appointees ruled for sex discrimination plaintiffs on the interest issue in 44.8 percent of the cases, and Kennedy and Johnson appointees ruled for plaintiffs on this issue in 57.9 percent of the cases, Carter appointees ruled for plaintiffs in an overwhelming 81.5 percent of the cases. Both district court and appellate judges appointed by Carter exhibited this same strongly pro-plaintiff record. ${ }^{284}$ The

${ }^{261}$ See id at 65, 72. See also Gottschall, 70 Judicature at 52,54 (cited in note 248) (reporting that in sex discrimination cases decided by the U.S. Courts of Appeals between 1983 and 1984, Kennedy/Johnson appointees voted more liberally than Nixon/Ford appointees). In Carp and Rowland's study, as in our data set, Roosevelt and Truman appointees combined also had slightly more liberal voting records than Eisenhower appointees in all cases as well as in the subset of civil rights and civil liberties cases. See Carp and Rowland, Policymaking and Politics at 65, 72 (cited in note 246). Because our data set includes only two cases decided by Roosevelt and Truman appointees, however, we decline to draw conclusions about those judges.

${ }^{262}$ Id at 70. For a discussion of the way the various presidents approached judicial appointments, and of the opportunities and constraints they encountered in appointing judges who were in tune with their own political and personal philosophies, see id at 53-64.

${ }^{263}$ Excluding cases decided by Carter and Reagan appointees from our data set, Democratic appointees voted for sex discrimination plaintiffs in $57.1 \%$ of the cases, and Republican appointees voted for plaintiffs in $44.4 \%$ of the cases.

264 Among district court judges appointed by Carter, $85.7 \%$ (6 out of 7 ) ruled for plaintiffs on the lack of interest issue in sex discrimination cases. Similarly, among appellate 
Carter appointees' record is not simply a function of the fact that they assumed the bench in the more recent 1978-89 period, when the tides may have begun to turn in plaintiffs' favor among the judiciary as a whole. Even in the 1978-89 period alone, Carter appointees voted for sex discrimination plaintiffs far more frequently than previous presidential appointees. ${ }^{285}$ In fact, the data suggest that the rise in plaintiffs' success rates in the more recent period is attributable to advances initiated by the Carter appointees, rather than the other way around. ${ }^{286}$

The pro-plaintiff record of the Carter appointees in sex discrimination cases is consistent with the findings of other studies, ${ }^{267}$ as well as with the political commentators' expectations. In light of Carter's opportunity to appoint large numbers of new judges, his degree of influence with the Senate Judiciary Committee, and his strategy of making partisan appointments while increasing the number of minorities and women on the bench, commentators predicted that Carter would be able to exert a strong liberal influence on lower federal court decisions. ${ }^{288}$ The timing was right with respect to the lack of interest argument. The Supreme Court's 1977

court judges appointed by Carter, $80 \%$ (16 out of 20 ) ruled for plaintiffs on this issue in sex discrimination cases.

${ }^{203}$ In sex discrimination cases decided in the 1978-89 period, Roosevelt and Truman appointees voted for plaintiffs in $50 \%$ ( 1 out of 2 ) of the cases; Eisenhower appointees did so in $40 \%$ ( 2 out of 5 ) of the cases; Kennedy and Johnson appointees did so in $61.5 \%$ (8 out of 13) of the cases; and Nixon and Ford appointees did so in $42.3 \%$ (11 out of 26 ) of the cases. Because all the decisions by Carter and Reagan appointees occurred after 1977, their voting records for the 1978-89 period are those shown in Table 10A: Carter appointees voted for plaintiffs in $81.5 \%$ (22 out of 27 ) of the cases, and Reagan appointees did so in $75 \%$ (6 out of 8) of the cases.

${ }^{268}$ In sex discrimination cases, plaintiffs' success rate rose from $48.3 \%$ in $1978-83$ to $78.6 \%$ in $1984-89$. This increase is largely attributable to the decisions of courts controlled by Carter appointees (defined to include district judges appointed by Carter and courts of appeals panels in which Carter appointees formed a majority). Even in the 1978-83 period, Carter-controlled courts were more likely to rule in favor of plaintiffs than other courts; Carter-controlled courts ruled for plaintiffs in $60 \%$ (3 out of 5) of the cases, whereas other courts did so in $45.8 \%$ (11 out of 24 ) of the cases. Yet, because Carter appointees controlled the courts in only $17.2 \%$ of the cases decided in that period, their influence on plaintiffs' success rates was not that substantial. By the 1984-89 period, however, Carter appointees controlled the courts in $57.1 \%$ of the cases. In addition, the disparity between their decisions and the decisions of other courts grew: Carter-controlled courts ruled for plaintiffs in $100 \%$ ( 8 out of 8 ) of the cases, whereas other courts did so in $50 \%$ ( 3 out of 6 ) of the cases. Thus, the Carter appointees made a substantial contribution toward increasing plaintiffs' success rates in sex discrimination cases after 1984.

${ }^{287}$ See, for example, Gottschall, 70 Judicature at 52, 54 (cited in note 248) (reporting that in sex discrimination cases decided by the U.S. Courts of Appeals between 1983 and 1984, Carter appointees' voting record was more liberal than any other group of appointees).

${ }^{208}$ See, for example, Carp and Rowland, Policymaking and Politics at 82 (cited in note 246). 
decisions expanding the lower courts' discretion over the lack of interest argument may have provided the newly-appointed Carter judges with an unprecedented opportunity to reject this rationalization for job segregation by sex.

In sex discrimination cases, the only group of presidential appointees whose record fails to conform to conventional political intuitions are the Reagan appointees. To date, Reagan appointees have voted for sex discrimination plaintiffs on the lack of interest issue only slightly less frequently than Carter appointees (and more frequently than Johnson and Kennedy appointees). This trend is inconsistent with the general wisdom about the direction of Reagan's influence on the judiciary, and with the findings of other empirical studies which have reported that Reagan appointees vote far more conservatively than Carter, Johnson, and Kennedy appointees in sex discrimination cases and in civil rights cases generally. ${ }^{269}$ One might argue that the Carter appointees helped create a pro-plaintiff body of precedent and a liberal understanding of the lack of interest issue that has influenced and constrained their generally more conservative Reagan-appointed successors. Such an interpretation is premature, however. At the time we compiled our data set, only five different Reagan appointees had addressed the lack of interest issue, ${ }^{270}$ and at least one of these five judges may be more liberal than the typical Reagan appointee. ${ }^{271}$ In addition, all of the Reagan appointees confronted this issue in the appellate context, where the norms of collegiality and the obligation to justify dissenting views may have permitted them less freedom to give expression to their own partisan val-

${ }^{269}$ See, for example, Gotschall, 70 Judicature at 52-54 (cited in note 248) (sex discrimination cases); Ronald Stidham and Robert A. Carp, Exploring Regionalism in the Federal District Courts, 18 Publius 113, 119-20 (1988); Ronald Stidham and Robert A. Carp, Judges, Presidents, and Policy Choices: Exploring the Linkage, 68 Soc Sci Q 395, 399-401 (1987).

270 Although Table 10A shows eight decisions by Reagan appointees in sex discrimination cases, there were actually only five different Reagan appointees ruling on this issue in five separate cases. See Wheeler v City of Columbus, Miss., 686 F2d 1144 (5th Cir 1982) (Garwood); Babrocky v Jewel Food Co., 773 F2d 857 (7th Cir 1985) (Eschbach); Catlett v Missouri Highway \& Transportation Comm'n, 828 F2d 1260 (8th Cir 1987) (Fagg and Magill); Palmer v Shultz, 815 F2d 84 (DC Cir 1987) (Bork); and EEOC v Sears, Roebuck \& Co., 839 F2d 302 (7th Cir 1988) (Eschbach). Because in Palmer and Sears the court addressed the lack of interest issue separately in connection with two different claims, each of these cases is double-counted in our data set.

271 Although he was appointed by President Reagan to the Seventh Circuit in 1981, Judge Eschbach had been appointed by President Kennedy to the district court in 1962. 
ues. ${ }^{272}$ In fact, in all but one of the cases in our data set, the Reagan appointee simply joined in the opinion of a more senior colleague. ${ }^{273}$ It is doubtful that the decisions of the handful of Reagan-appointed appellate judges in our data set accurately reflect the way the entire group of Reagan-appointed judges will resolve this issue in the future, particularly as they are joined by increasing numbers of Bush appointees.

Although in sex discrimination cases judges' decisions on the lack of interest issue generally break down along predictable partisan lines, in race discrimination cases the patterns do not conform to conventional partisan expectations. As Table 10 shows, Democratic judges, appointees, and courts were not significantly more likely to rule in favor of race discrimination plaintiffs than their Republican counterparts. ${ }^{274}$ Nor do the voting records of the presidential appointees in race discrimination cases square neatly with larger trends in judicial voting patterns. Only the sharp retreat from a pro-plaintiff position on the part of Nixon/Ford appointees relative to their Kennedy/Johnson predecessors conforms to the patterns reported by Carp and Rowland. In our data set, Eisenhower appointees voted for plaintiffs as frequently (in fact, somewhat more frequently) than their Kennedy/Johnson successors. Carter appointees displayed a strongly anti-plaintiff record, re-

${ }^{272}$ See, for example, Schwab and Eisenberg, Influence of Judicial Background at 3 (cited in note 78) ("Multiple decisionmakers may check judicial discretion. Judges feel pressure to be careful lawyers and craftsmen [sic]. If one's fellow judges evaluate the legal arguments a certain way, concern for collegiality and respect pushes one to conform to these views, regardless of whether the result is liberal or conservative, unless the judge can make plausible counter legal arguments.").

${ }^{273}$ See Wheeler, 686 F2d 1144 (Garwood joining in the opinion of Clark); Babrocky, 773 F2d 857 (Eschbach joining in the opinion of Cummings); Palmer, 815 F2d 84 (Bork joining in the opinion of Wald); Sears, 839 F2d 302 (Eschbach joining in the opinion of Wood). Sears was the only one of these cases in which the court of appeals accepted the lack of interest argument, and the only case that involved a dissent. 839 F2d at 360-66 (Cudahy concurring in part and dissenting in part).

In Catlett, however, Judge Fagg, a Reagen appointee, wrote an opinion joined by Judge Magill, another Reagan appointee, and by Judge Bright, a Johnson appointee. 828 F2d at 1260. The panel affirmed the district court's rejection of the lack of interest argument.

${ }^{274}$ The difference in Democratic and Republican appointees' voting records in race discrimination cases in Panel $A$ is not statistically significant ( $p$-value $=.40$ ) - nor is the difference in Democratic and Republican judges' voting records in Panel B (p-value $=.43$ ), or the difference in plaintiffs' success rates in cases decided by Democratically-controlled and Republican-controlled courts in Panel C (p-value $=.55$ ). 
jecting the lack of interest argument less frequently than any other group of presidential appointees (only 26.7 percent of the time). ${ }^{275}$

These puzzling patterns make sense when analyzed in historical context. In race discrimination cases, as our separate analyses of judges' voting patterns for the 1967-77 and 1978-89 periods in Table 11 disclose, judicial decisions on the lack of interest argument are explained by the era in which the decisions were made rather than by the judges' political affiliations. In the 1967-77 era, there was a strong bipartisan consensus that patterns of racial segregation should not be rationalized as the expression of minorities' own lack of interest in higher-paying jobs. Both Democrats and Republicans and Eisenhower and Kennedy/Johnson appointees overwhelmingly voted to reject the lack of interest argument. The shift toward a less pro-plaintiff position on the part of the Nixon appointees suggests that by the end of the early period, the proplaintiff consensus on the lack of interest issue was beginning to break down.

275 Although we are not aware of any other study reporting such an extreme turn toward conservatism on the part of Carter appointees in race discrimination cases, Gottschall's study does report that in race discrimination cases decided by the U.S. Courts of Appeals between July 1, 1983 and December 31, 1984, Carter appointees voted more conservatively than Kennedy/Johnson appointees (but more liberally than Nixon/Ford and Reagan appointees). See Gottschall, 70 Judicature at 52, 54 (cited in note 248).

In addition, Gottschall's study reports a finding which is consistent with our finding that Carter appointees voted more liberally in sex discrimination cases than in race discrimination cases. In Gottschall's study, in unanimous and nonunanimous decisions combined, Carter appointees voted in favor of plaintiffs in $63 \%$ of all sex discrimination cases but in only $46 \%$ of all race discrimination cases. See id at 54 . But see id at 52 (reporting that in non-unanimous appellate decisions, Carter appointees voted in favor of race discrimination plaintiffs slightly more frequently than sex discrimination plaintiffs). 
Table 11: Percentage of Judicial Decisions in Favor of Plaintiffs in Early and Modern Race Discrimination Cases, by Judges' Political Affiliations

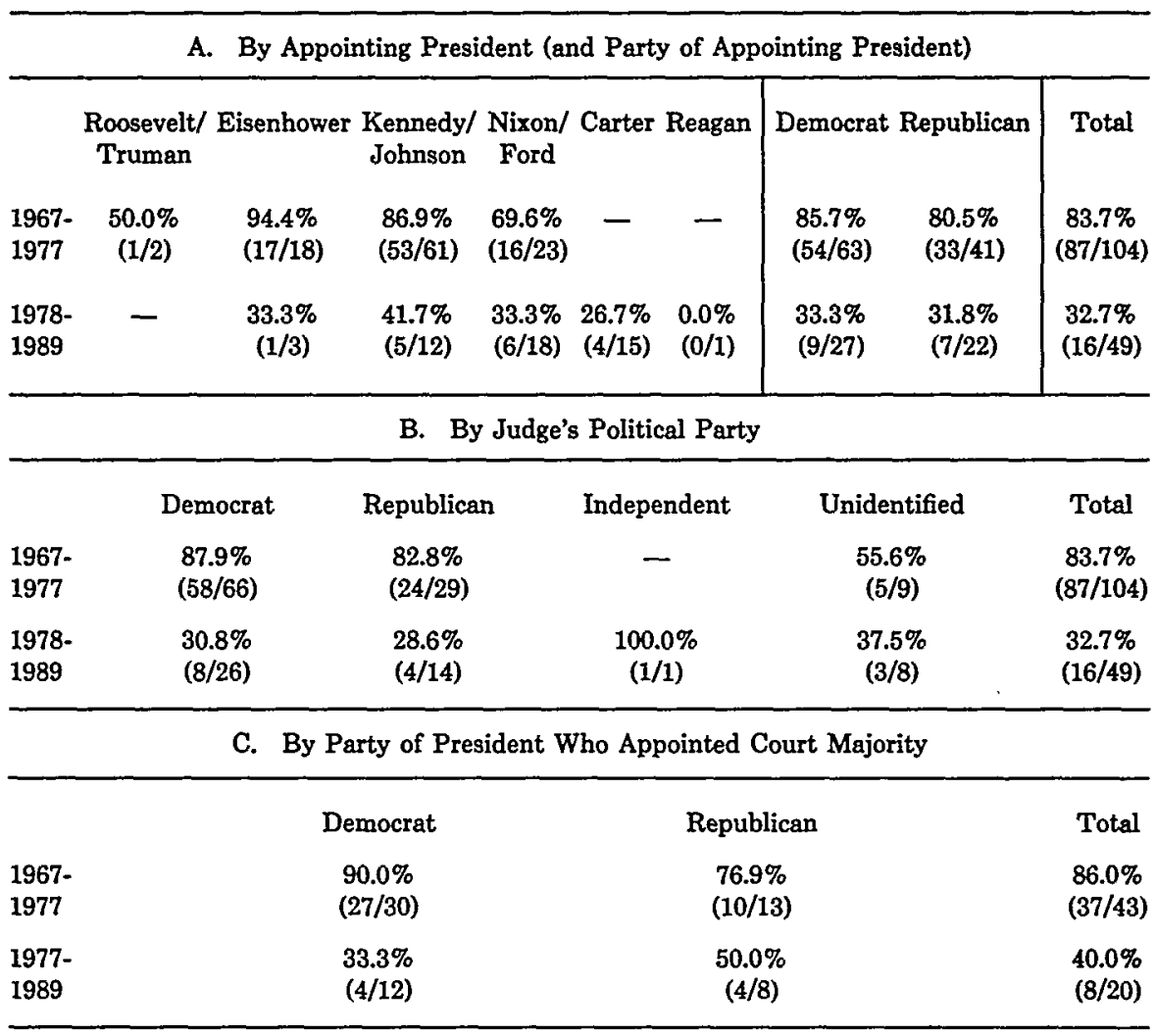

By the 1978-89 period, the bipartisan pro-plaintiff consensus had become a pro-employer consensus. The proportion of Democratic appointees who rejected the lack of interest argument declined from 85.7 percent in the early period to 33.3 percent in the modern period; the proportion of Republican appointees who rejected this argument similarly declined from 80.5 percent to 31.8 percent. This same trend occurred among every group of presidential appointees, liberal and conservative alike. Eisenhower, Kennedy/Johnson, and Nixon appointees all embraced the lack of interest defense in the vast majority of cases in the modern period. Given the general conservatism among judges in this era, the Carter appointees' record is less surprising; they simply voted in line with the pro-employer tendencies of their contemporaries. As Table 11 makes clear, race discrimination plaintiffs' declining success on the lack of interest argument cannot be attributed to Rea- 
gan's influence. Only one race discrimination case in our data set involved a Reagan appointee.

These analyses of judges' voting records provide further elaboration for our earlier conclusions about the sources of the two major disparities in plaintiffs' success on the lack of interest argument. Section II showed that historically, sex discrimination plaintiffs have fared worse than race discrimination plaintiffs not because their cases presented a weaker basis for rejecting the lack of interest argument, but because judges have brought to their interpretations of the evidence and facts a biased set of assumptions about women's work aspirations. That judges with Republican affiliations, and not those with Democratic affiliations, are primarily responsible for the difference in sex and race discrimination plaintiffs' success rates reinforces the conclusion that conservative judicial bias explains the disparity.

The analyses of judges' voting patterns in race discrimination cases place an even more pessimistic gloss on our previous observations about the decline in race discrimination plaintiffs' success. Section III showed that a shift in the merits of the race discrimination cases selected for litigation cannot fully explain this decline. Rather, since 1978, judges have reacted less favorably to evidence they once relied on heavily to reject the lack of interest argument. That this conversion occurred among judges of all political affiliations-Democrats and Republicans, Eisenhower, Kennedy/Johnson, and Nixon/Ford appointees alike-suggests a significant transformation in judicial consciousness. After a decade of efforts to enforce Title VII, federal judges apparently began to share the general public's belief that employment discrimination against minorities had been largely eradicated. In the wake of this shift in perceptions, judges have become more predisposed to interpret racial segregation as the expression of minorities' own lack of interest in higher-paying jobs.

\section{CONCLUSION}

Our analyses strongly suggest that the courts have imported bias into their decisions in cases raising the lack of interest argument. During the 1965-89 period as whole, the courts have required sex discrimination plaintiffs to meet more difficult standards of proof than race discrimination plaintiffs to refute the lack of interest argument. Since the late 1970s, the courts have also changed their approach to the lack of interest argument in race discrimination cases to one less favorable to plaintiffs. They have moved toward a conservative understanding of racial segregation 
that converges with the way they have always understood sex segregation in employment.

Title VII promised minorities and women equality. For the first decade of Title VII enforcement, judges kept faith with this promise in race discrimination cases. They created a Title VII jurisprudence that expressed our nation's highest ideals of openness and equality. When employers sought to justify racial segregation as the expression of minorities' own lack of interest in better jobs, the courts almost universally rejected this argument. They assumed that any racial differences in job preferences were the product of the very labor market inequalities that plaintiffs were seeking to dismantle. By acknowledging that people's work aspirations are shaped in the context of what larger institutional and legal environments define as possible, the courts refused to allow employers to escape responsibility for continuing labor market discrimination by pinning the blame on its victims.

In sex discrimination cases, and in more recent race discrimination cases, however, the courts have undermined Title VII's transformative capacity. Through their widespread acceptance of the lack of interest argument, judges have interpreted the statute to embody the same stereotypes that have traditionally been used to justify women's and minorities' economic disadvantage. Throughout history, the dominant culture has rationalized women's employment in low-paying, dead-end jobs as the expression of their own preordained preferences for suitably "feminine" work. Similarly, our society has rationalized minorities' inferior economic status as the reflection of their own lack of initiative. Whereas Title VII jurisprudence once rejected and stood in tension with such cultural attitudes, it now incorporates them to a large extent. By portraying job segregation as the product of minorities' and women's preexisting job preferences, and attributing these preferences to forces beyond employers' control, the courts have privatized job segregation and placed it beyond the reach of the law. Unless the courts change course, Title VII may someday be perceived as a short-lived, but failed, experiment in equality. 
